B O N N $N$ N I L L E Measurement of Lake Roosevelt Biota in Relation to Reservoir Operations

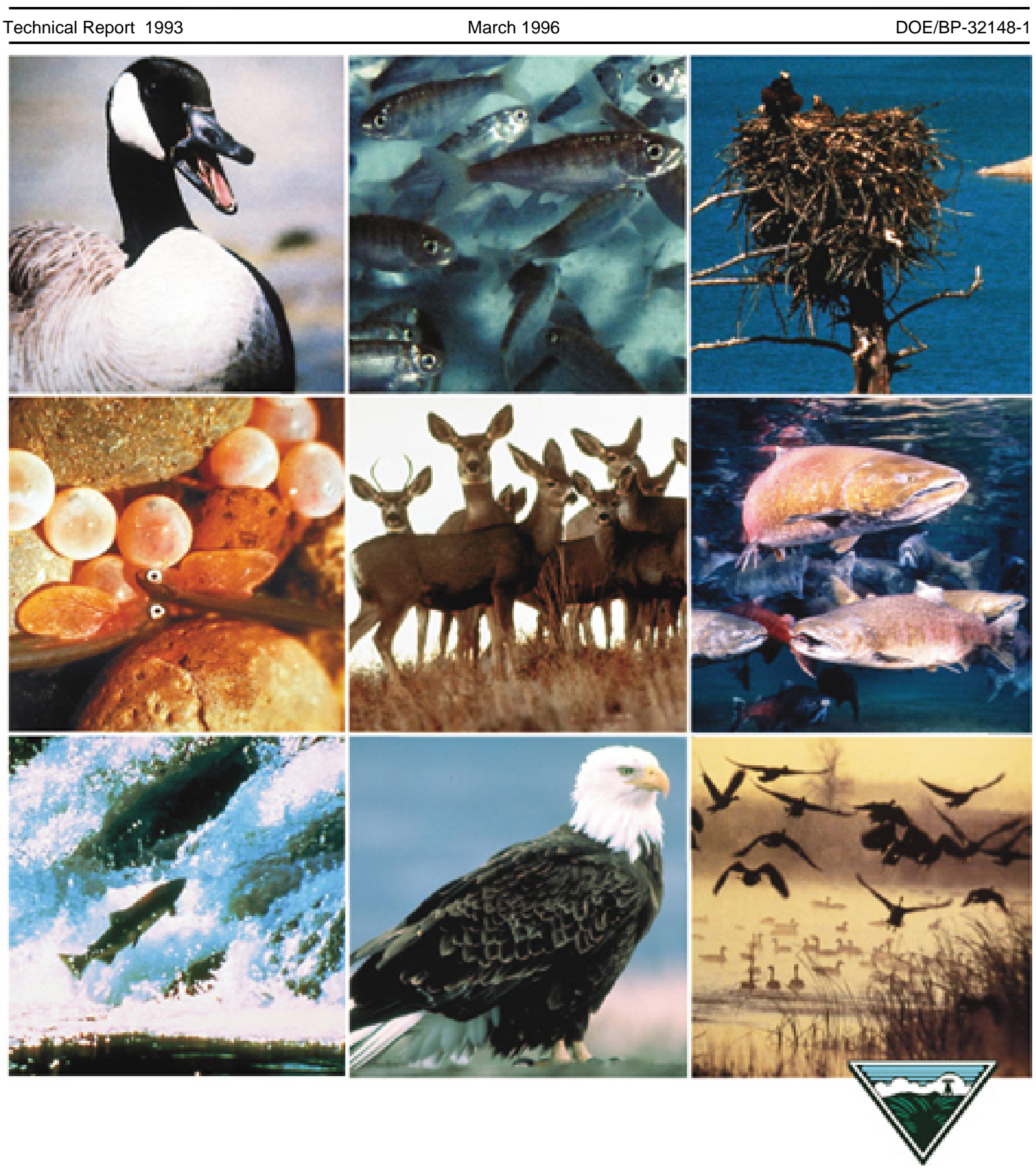


This Document should be cited as follows:

Voeller, Amy, "Measurement of Lake Roosevelt Biota in Relation to Reservoir Operations", 1993 Technical Report, Project No. 199404300, 117 electronic pages, (BPA Report DOE/BP-32148-1)

\author{
Bonneville Power Administration \\ P.O. Box 3621 \\ Portland, OR 97208
}

This report was funded by the Bonneville Power Administration (BPA), U.S. Department of Energy, as part of BPA's program to protect, mitigate, and enhance fish and wildlife affected by the development and operation of hydroelectric facilities on the Columbia River and its tributaries. The views in this report are the author's and do not necessarily represent the views of BPA. 


\title{
MEASUREMENT OF LAKE ROOSEVELT BIOTA IN RELATION TO RESERVOIR OPERATIONS
}

\author{
FINAL REPORT 1993
}

\author{
Prepared by: \\ Amy C. Voeller \\ Spokane Tribal Fish and Wildlife Center \\ Spokane Tribe of Indians \\ Wellpinit, WA 99040
}

\author{
Prepared for: \\ U.S. Department of Energy \\ Bonneville Power Administration \\ Environment, Fish and Wildlife \\ P.O. Box 3621 \\ Portland, OR 97208-3621 \\ Project Number 94-043 \\ Modification Number 001 \\ Contract Number 94BI32 148
}




\begin{abstract}
The purpose of this study was to collect biological data from Lake Roosevelt to be used in the design of a computer model that will predict biological responses to reservoir operations as part of the System Operation Review Program. This study worked in conjunction with Lake Roosevelt Monitoring Project which investigated the effectiveness of two kokanee salmon hatcheries. This report summarized the data collected from Lake Roosevelt from 1993 and includes limnological, reservoir operation, zooplankton, benthic macroinvertebrate, experimental trawling, and net-pen rainbow trout tagging data. Major components of the Lake Roosevelt model include quantification of impacts to zooplankton, benthic macroinvertebrates, and fish caused by reservoir drawdowns and low water retention times.
\end{abstract}

Reservoir operations influence the morphology of a reservoir and habitat for fish and their food. The thermal structure of a reservoir is influenced by the large seasonal inflow and outflow volumes. In Lake Roosevelt, reservoir operation caused the lake elevations to decline continually to $1,255 \mathrm{ft}$ in March, then actively refilling to $1,280 \mathrm{ft}$ on April 25th. Mean yearly reservoir elevation was $1,277 \mathrm{ft}$. Mean monthly water retention time did not go below thirty days for any month, while daily water retention times ranged from 38 days in December to 87 days in April.

Zooplankton data was collected monthly at nine sites in 1993. Lake Roosevelt experienced two peaks of daphnia spp. densities. High densities of zooplankton were found in the lower end of the reservoir supporting the hypothesis that flushing of reservoir water increases downstream densities, biomass, and entrainment.

Benthic macroinvertebrate data was collected March through September 1993 and showed high re-colonization rates of benthic macroinvertebrates in dewatered areas. Densities and weights were consistently composed of midges and worms. Emergence data was collected in June and July only, due to trap damage and vandalism. Data supported the hypothesis that benthic macroinvertebrate sampling is not an effective sampling device for Lake Roosevelt and will not continue.

The Idaho Department of Fish and Game in conjunction with the Spokane Tribe of Indians trawled Lake Roosevelt in August, 1993 to determine if trawling was a suitable methodology to estimate kokanee densities in the reservoir. No kokanee were collected in eleven trawls, and no layer of kokanee could be seen with extensive echosounding. Densities of kokanee in Lake Roosevelt appear to be too low for collection by mid-water trawling. Trawling at different times of the year may be a suitable way to estimate kokanee densities in the reservoir. However, warm water temperatures, the lack of stratification, predation, mortality, and low water retention times may result in high entrainment losses and a low population of kokanee in Lake Roosevelt.

A total of 21,255 net-pen rainbow trout were tagged at locations throughout the reservoir. Three hundred, fifty-two tags were returned from angler fishing in Lake Roosevelt or below, and 106 tags were from fish tagged in 1993. Trends in tag returns continue to indicate that entrainment of Lake Roosevelt net-pen fish are influenced by water retention times and release times. Fish released later in the year have an increased chance of remaining in the reservoir. Factors influencing entrainment include a smoltification type process in Lake Roosevelt net-pen fish and low water retention times. Please see the Lake Roosevelt Monitoring Program's 1993 annual report for creel data and pressure estimate changes over the duration of both projects. 


\section{ACKNOWLEDGMENTS}

The project biologist gratefully acknowledges Charlie Craig (Bonneville Power Administration) for his support and patience, Dave Geist and Dan Epstein (Battelle Pacific Northwest Laboratories), and Keith Underwood (Lake Roosevelt Monitoring Program). Special thanks to John Shields, Hank Etue, Bill Matt Jr., and Jason Wynecoop who collected and analyzed field data. The following agencies or groups are acknowledged for their contributions to the project: Army Corps of Engineers, Battelle Pacific Northwest Laboratories, Bonneville Power Administration, Bureau of Reclamation, Colville Confederated Tribes, Hunters High school, Idaho Department of Fish and Game, Fish Passage Center, Lake Roosevelt Forum, Montana Department of Fish, Wildlife and Parks, National Park Service, Nez Perce Fisheries, Reservoir Control Center, U.S. Geological Survey, and U.S. Fish and Wildlife Service. Special thanks to Dr. Allan Scholz, (Eastern Washington University), Rob Pierson (Bonneville Power Administration), Larry Goodrow and Mary Vemer (Spokane Tribe of Indians), and Janelle Griffith (previous project manager).

This project was supported by a contract from the U.S. Department of Energy, Bonneville Power Administration, Contact No.DE-B179-88BP91819, Modification No. A006, Project No. 88-63. 


\section{TABLE OF CONTENTS}

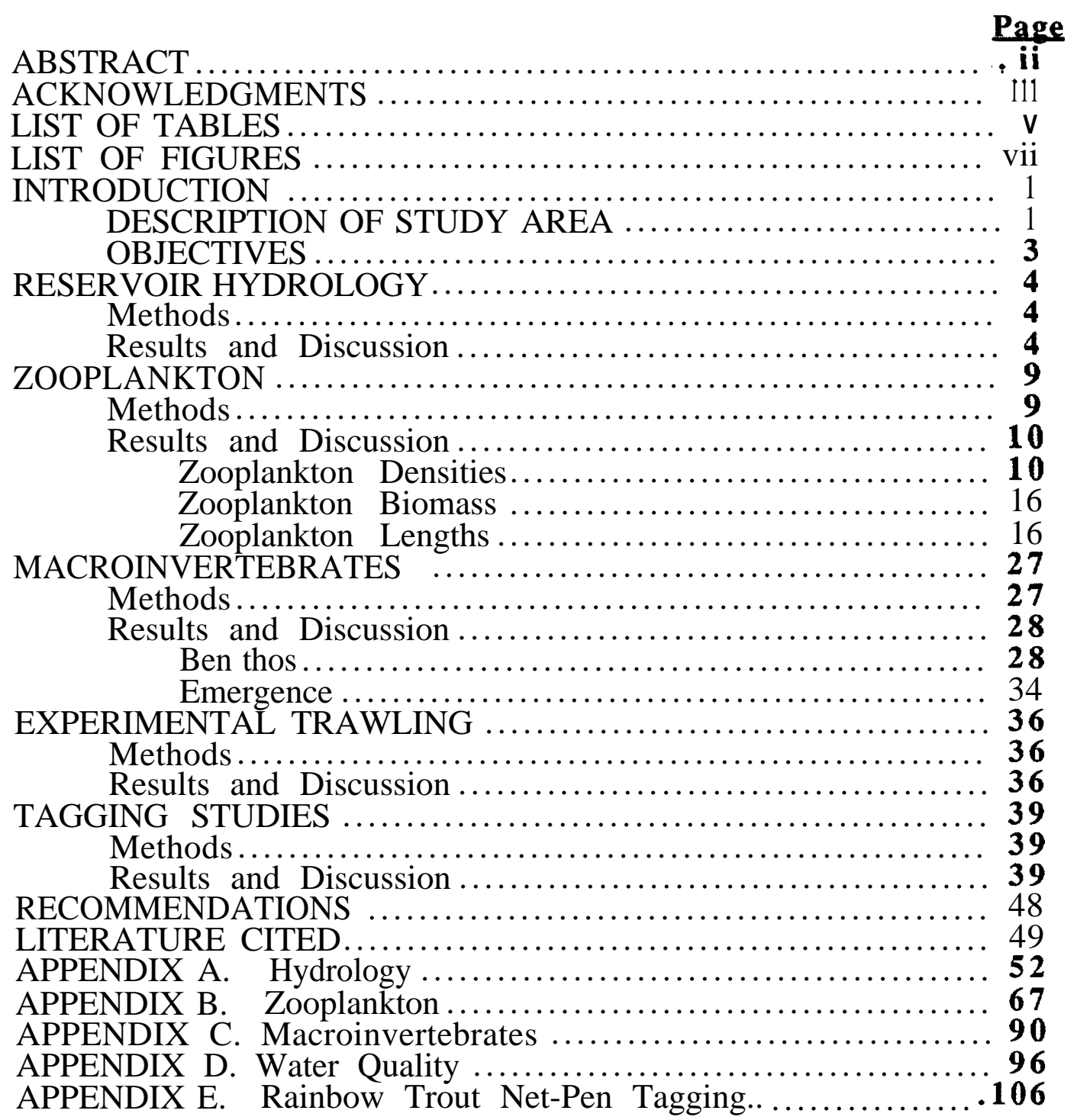




\section{LIST OF TABLES}

Table 1 Monthly and annual means for reservoir inflow, outflow, elevation, storage capacity, and water retention time for Lake Roosevelt in 1993.

Table 2 Monthly and annual means for reservoir inflow, outflow, elevation, storage capacity, and water retention time for Lake

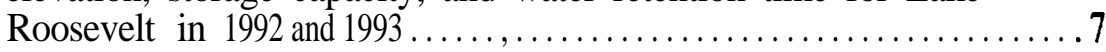

Table 3 Synoptic list of zooplankton taxa identified in Lake Roosevelt during the 1993 study period.....

Table 4 Mean monthly density values $\left(\mathrm{Hm}^{3}\right)$ and standard deviations of different categories of zooplankton at Gifford (Index Station 2) in 1993.

Table 5 Mean monthly density values $\left(\# / \mathrm{m}^{3}\right)$ and standard deviations of different categories of zooplankton at Porcupine Bay (Index Station 4) in 1993.

Table 6 Mean monthly density values $\left(\# / \mathrm{m}^{3}\right)$ and standard deviations of different categories of zooplankton at Seven Bays (Index Station 6) in 1993.

Table $7 \quad$ Mean monthly density values $\left(\# / \mathrm{m}^{3}\right)$ and standard deviations of different categories of zooplankton at Spring Canyon (Index Station 9) in 1993.

Table $8 \quad$ Mean monthly biomass values $\left(\mathrm{mg} / \mathrm{m}^{3}\right)$ of different Cladocera species at Gifford (Index Station 2) in 1993 . . . . . .................. 20

Table 9 Mean monthly biomass values $\left(\mathrm{mg} / \mathrm{m}^{3}\right)$ of different Cladocera species at Porcupine Bay (Index Station 4) in 1993.............. 20

Table 10 Mean monthly biomass values $\left(\mathrm{mg} / \mathrm{m}^{3}\right)$ of different Cladocera species at Seven Bays (Index Station 6) in 1993................. 21

Table 11 Mean monthly biomass values $\left(\mathrm{mg} / \mathrm{m}^{3}\right)$ of different Cladocera species at Spring Canyon (Index Station 9) in 1993.............2 1

Table 12 Mean monthly size values $(\mathrm{mm})( \pm$ S.D.) of different Cladocera species at Gifford (Index Station 2) in 1993 ..................... 22

Table 13 Mean monthly size values $(\mathrm{mm})( \pm$ S.D.) of different Cladocera species at Porcupine Bay (Index Station 4) in 1993.............23

Table-14 Mean monthly size values $(\mathrm{mm})( \pm$ S.D.) of different Cladocera species at Seven Bays (Index Station 6) in 1993. . . . . . . . . . . ..24 
Table 15 Mean monthly size values (mm) ( \pm S.D.) of different Cladocera species at Spring Canyon (Index Station 9) in 1993. . . . . . . . . . 25

Table 16 Mean number $\left(\# \mathrm{~m}^{3}\right)$ and weight $\left(\mathrm{g} / \mathrm{m}^{*}\right)$ density values for groups of benthic organisms at Gifford sampling locations on Lake

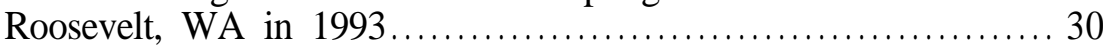

Table 17 Mean number $\left(\# \mathrm{~m}^{3}\right)$ and weight $\left(\mathrm{g} / \mathrm{m}^{*}\right)$ density values for groups of benthic organisms at Porcupine Bay sampling locations on Lake

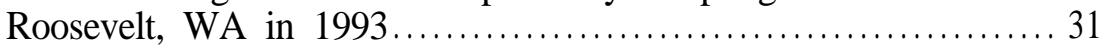

Table 18 Mean number $\left(\# \mathrm{~m}^{3}\right)$ and weight $\left(\mathrm{g} / \mathrm{m}^{2}\right)$ density values for groups of benthic organisms at Seven Bays sampling locations on Lake Roosevelt, WA in 1993.

Table 19 Mean number $\left(\# \mathrm{~m}^{3}\right)$ and weight $\left(\mathrm{g} / \mathrm{m}^{2}\right)$ density values for groups of benthic organisms Spring Canyon sampling locations on Lake

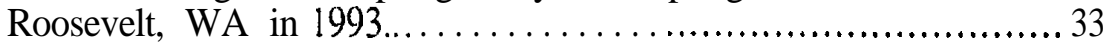

Table $20 \quad$ Mean number $\left(\# / \mathrm{m}^{2}\right)$ density values for groups of benthic organisms captured in emergence traps located at Gifford, Porcupine Bay, Seven Bays, and Spring Canyon, Lake Roosevelt, WA in 1993.

Table 21 Summary of release dates, numbers, and subsequent capture locations of net-pen rainbow trout tagged and released from Kettle Falls.

Table 22 Summary of release dates, numbers, and subsequent capture locations of net-pen rainbow trout tagged and released from Gifford

Table 23 Summary of release dates, numbers, and subsequent capture locations of net-pen rainbow trout tagged and released from Hunters . . .

Table $24 \quad$ Summary of release dates, numbers, and subsequent capture locations of net-pen rainbow trout tagged and released from Seven Bays.

Table 25 Summary of release dates, numbers. and subsequent capture locations of net-pen rainbow trout tagged and released from Lincoln. . .

Table 26 Summary of release dates, numbers, and subsequent capture locations of net-pen rainbow trout tagged and released from Keller Ferry

Table $27 \quad$ Summary of rainbow trout release times, water retention times and subsequent recapture numbers and percentages $\ldots \ldots \ldots \ldots \ldots \ldots \ldots .47$ 


\section{LIST OF FIGURES}

Figure

Figure 1 Map of Lake Roosevelt, WA showing the locations of sampling and tagging stations

Figure 2 Mean monthly Lake Roosevelt reservoir elevations from 1991

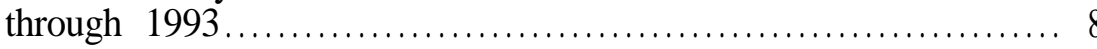

Figure 3 Mean monthly Lake Roosevelt water retention time from 1991

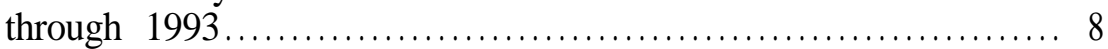

Figure 4 Mean monthly Daphnia spp. density $\left(\# \mathrm{~m}^{3}\right)$ at Gifford, Porcupine Bay, Seven Bays, and Spring Canyon in $1993 \ldots \ldots \ldots \ldots \ldots \ldots . . . \ldots 17$

Figure 5 Mean monthly zooplankton density $\left(\mathrm{Am}^{3}\right)$ at Gifford, Porcupine Bay, Seven Bays, and Spring Canyon in $1993 \ldots \ldots \ldots \ldots \ldots \ldots \ldots$

Figure 6 Density and water retention times at Porcupine Bay from 1991

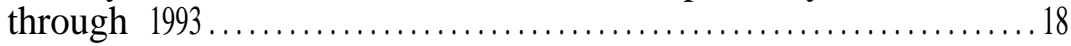

Figure 7 Density and water retention times at Seven Bays from 1991 through 1993

Figure 8 Benthic macroinvertebrate emergence trap used on Lake Roosevelt

Figure 9 Lengths of sculpins, burbot, and lake whitefish caught trawling in Lake Roosevelt, August 1993 . . . . 


\section{INTRODUCTION}

The purpose of this research project is to collect data to model resident fish requirements for Lake Roosevelt as part of the Bonneville Power Administration (BPA), Bureau of Reclamation (BOR), and U.S. Army Corps of Engineer's (ACE) System Operation Review. The System Operation Review (SOR) is a tri-agency team functioning to review the use and partitioning of Columbia Basin waters. User groups of the Columbia have been defined as power, irrigation, flood control, anadromous fish, resident fish, wildlife, recreation, water quality, navigation, and cultural resources.

Once completed the model will predict biological responses to different reservoir operation strategies. The model developed for resident fish is based on a model developed by Montana Department of Fish, Wildlife, and Parks for resident fish requirements within Hungry Horse and Libby Reservoirs. While the Montana model predicts fish growth based on the impacts of reservoir operation and flow conditions on primary and secondary production levels, the Lake Roosevelt model will also factor in the effects of water retention time on zooplankton production levels and fish entrainment. Major components of the Lake Roosevelt model include quantification of impacts to zooplankton and benthic invertebrates caused by reservoir drawdowns and low water retention times and quantification of entrainment levels of fish as related to reservoir operations and water retention times.

In July 1991, BPA entered into a contract with the Spokane Tribe of Indians to initiate the System Operation Review process with continued research through 1995. The SOR project is a modification of the Lake Roosevelt Monitoring Project contract with BPA that studies the effects of kokanee reintroduction into Lake Roosevelt. This report contains the results of the resident fish SOR program for Lake Roosevelt from January through December 1993.

\section{DESCRIPTION OF STUDY AREA}

Lake Roosevelt is a mainstem Columbia River impoundment formed by the construction of Grand Coulee Dam in 1939 (Figure 1). Filled in 1941, the reservoir inundates 33,490 hectares at a full pool elevation of $393 \mathrm{~m}$ above mean sea level. It has a maximum width of $3.4 \mathrm{~km}$ and a maximum depth of $122 \mathrm{~m}$ (Stober et al. 1981). Grand Coulee Dam is a Bureau of Reclamation storage project operated primarily for power, flood control, and irrigation with secondary operations for recreation, fish, and wildlife. 


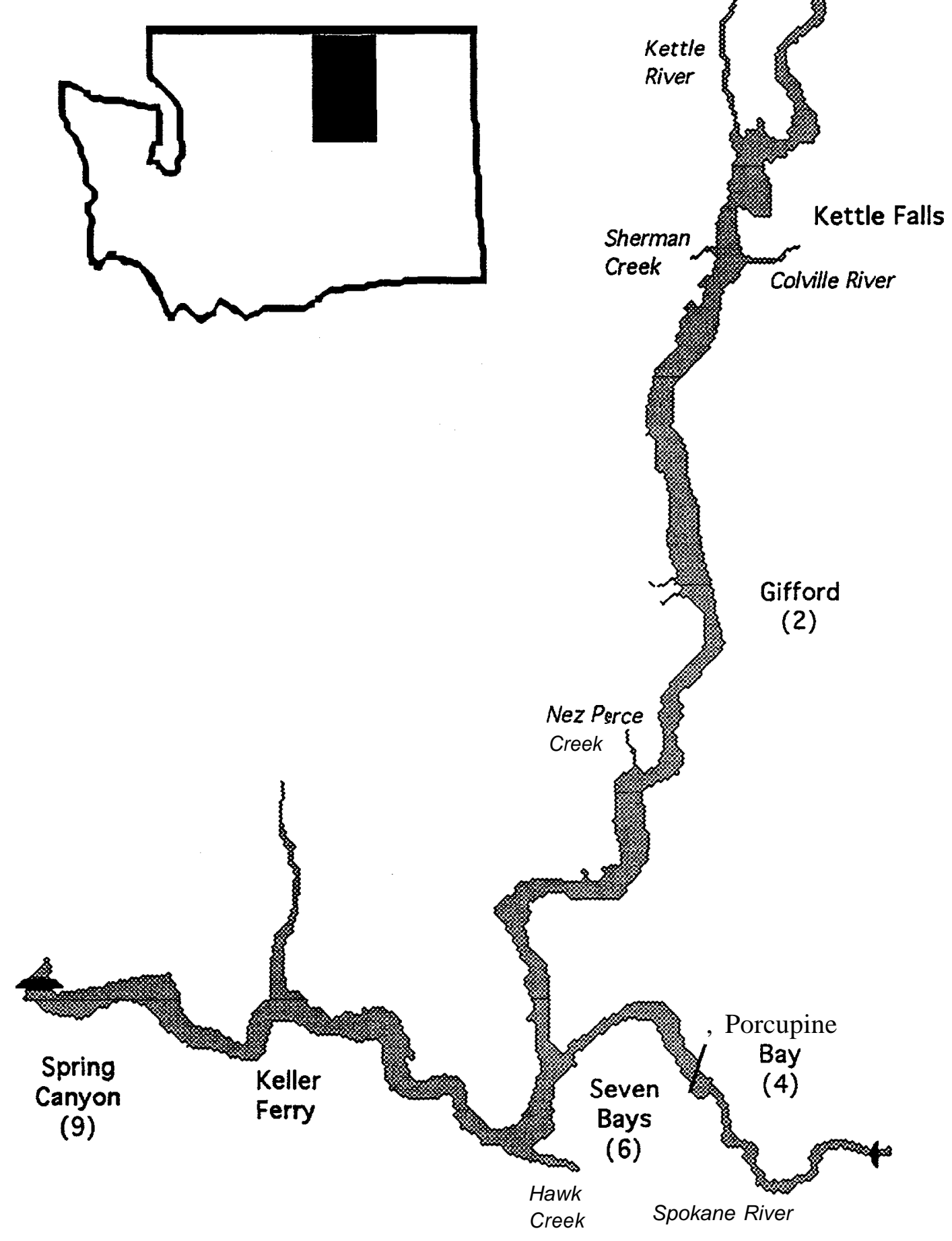

Figure 1. Majp of Lake Roosevelt, Washington showing the locations of sampling and tagging stations. 
OBJECTIVES - 1993

This study proposes to determine how reservoir operations effect reservoir biology in Lake Roosevelt. The specific study objectives are:

1. Determine reservoir hydrology, downstream flow constraints and how these effect reservoir operations;

2. Determine zooplankton biomass and density at four areas of the reservoir;

3. Determine benthic macroinvertebrate production levels and densities at differing reservoir strata;

4. Determine benthic insect emergence levels at differing reservoir strata;

5. Determine if trawling is a suitable methodology to estimate kokanee (Oncorhynchus nerka) densities in Lake Roosevelt.

6. Determine entrainment levels via placement of Floy tags in net-pen rainbow trout (Salmo gairdneri). 


\section{RESERVOIR HYDROLOGY}

Met hods

Water quality measurements of temperature, $\mathrm{pH}$, dissolved oxygen, conductivity, and oxygen reduction potential were collected using a Hydrolab Surveyor II at four sites in the reservoir. Samples were collected mid-channel at Gifford (location 2), Porcupine Bay (location 4), Seven Bays (location 6), and Spring Canyon (location 9) monthly in 1993

(Figure 1). This data collection continues procedures which began in 1991. Consult Appendix D for this data.

Reservoir elevations and water retention times were calculated from daily midnight reservoir elevation (ft) and total outflow (kcfs) summary reports for Grand Coulee Dam prepared monthly in 1993 by the U.S. Army Corps of Engineers, Reservoir Control Center in Portland, OR. Reservoir elevation ( $\mathrm{ft}$ ) was converted to volume of water stored (kcfsd) using a U.S. Army Corps of Engineers (1981) reservoir water storage table. Water retention time was calculated using the formula:

Water retention time (days) $\quad=\quad$ Reservoir volume $(\mathrm{kcfsd})$

Outflow (kcfs)

Daily values for each category were added and then divided by the number of days in each month to attain mean reservoir elevations and water retention times.

\section{Results and Discussion}

Table 1 summarizes mean monthly reservoir operations for Lake Roosevelt in 1993. Appendix A summarizes daily reservoir operations from January through December 1993. Lake Roosevelt was drawn down continually from December 1992, to 1,255 ft in March, then actively refilled to 1,280 on April 25th. The reservoir continued to fill toward fullpool and remained stable through September 27th. A second gradual drawdown occurred from October through December 1993. Mean reservoir elevations ranged from 1,256 feet in March to 1,287 feet in June, 1993. Mean yearly reservoir elevation was 1,277 feet. Mean outflows ranged from $48 \mathrm{kcsf}$ in April to $119 \mathrm{kcfs}$ in May, 1993 with a yearly mean of $84 \mathrm{kcfs}$.

Mean monthly water retention time did not go below thirty days for any month. 
Table 1. Monthly and annual means for reservoir inflow, outflow, elevation, storage capacity, and water retention time for Lake Roosevelt in 1993.

\begin{tabular}{|c|c|c|c|c|c|}
\hline MONTH & $\begin{array}{c}\text { INFLOW } \\
\text { (KCFS) }\end{array}$ & $\begin{array}{c}\text { OUTFLOW } \\
\text { (KCFS) }\end{array}$ & $\begin{array}{c}\text { RESERVOIR } \\
\text { ELAT) }\end{array}$ & $\begin{array}{c}\text { STORAGE } \\
\text { CAPACITY }\end{array}$ & $\begin{array}{c}\text { WATER } \\
\text { RETENTION } \\
\text { TIME (D) }\end{array}$ \\
\hline Jan. 1993 & 95.0 & 100.5 & 1267.5 & 3731.9 & 40.2 \\
\hline Feb. 1993 & 71.6 & 85.9 & 1263.5 & 3594.3 & 44.0 \\
\hline Mar. 1993 & 57.1 & 53.9 & 1256.0 & 3329.6 & 67.1 \\
\hline Apr. 1993 & 80.4 & 48.4 & 1271.8 & 3887.3 & 87.1 \\
\hline May 1993 & 132.0 & 119.0 & 1284.7 & 4375.4 & 39.4 \\
\hline Jun. 1993 & 100.8 & 95.67 & 1287.5 & 4487.3 & 49.55 \\
\hline Jul. 1993 & 104.1 & 97.24 & 1286.4 & 4444.5 & 46.9 \\
\hline Aug. 1993 & 87.7 & 81.7 & 1285.9 & 4422.2 & 56.8 \\
\hline Sept. 1993 & 67.9 & 73.0 & 1281.3 & 4242.7 & 61.0 \\
\hline Oct. 1993 & 65.0 & 62.5 & 1281.2 & 4266.3 & 73.5 \\
\hline Nov. 1993 & 77.1 & 84.2 & 1278.8 & 4150.9 & 51.4 \\
\hline Dec. 1993 & 86.5 & 109.9 & 1273.0 & 3930.8 & 37.5 \\
\hline Mean 1993 & 85 & 84 & 1277 & 4072 & 55 \\
\hline
\end{tabular}


Daily water retention times were above 30 days the majority of the year. However, January, February, May, and November all had periods of daily fluctuations in which water retention times were less that thirty days. Mean water retention times ranged from 38 days in December to 87 days in April, with a yearly mean of 55 days.

Table 2 compares inflows, outflows, reservoir elevations, storage capacities, and water retention times of 1992 to 1993. When comparing means for both 1992 and 1993 there are no extreme differences. However daily fluctuations from reservoir operations between the two years are different. The effect these differences have on the biota are unknown. Mean water retention times remained generally constant when comparing months for both years.

Figures 2 and 3 show the changes of monthly reservoir elevations and water retention times from 1991 through 1993. 1991 reservoir operations produced the lowest mean elevations and water retention times when compared to 1992 and 1993. The reduced water retention times in 1991 were thought to be the cause of the significant decreases in zooplankton density and biomass values (Griffith et al. 1994).

Reservoir operations influence the morphology of a reservoir and habitat for fish and their food. Changes in surface area, water volume, depth, shoreline development, in lake-filling, and water retention times are varied by the drawdown and refilling cycles of the reservoir. The amount of littoral area varies with reservoir elevation along with volume of water in the euphotic zone, volume of water in preferred temperature ranges for zooplankton and fish growth, an area of reservoir bottom dewatered. The thermal structure of reservoirs is influenced by the large seasonal inflow and outflow volumes (Woods 1982). 
Table 2. Monthly and annual means for reservoir inflow, outflow, elevation, storage capacity, and water retention time for Lake Roosevelt in 1992 and 1993.

\begin{tabular}{|c|c|c|c|c|c|}
\hline MONTH & $\begin{array}{c}\text { INFLOW } \\
\text { (KCFS) }\end{array}$ & $\begin{array}{c}\text { OUTFLOW } \\
\text { (KCFS) }\end{array}$ & $\begin{array}{c}\text { RESERVOIR } \\
\text { ELEVATION } \\
\text { (FT) }\end{array}$ & $\begin{array}{l}\text { STORAGE } \\
\text { CAPACITY } \\
\text { (KCFSD) }\end{array}$ & $\begin{array}{c}\text { WATER } \\
\text { RETENTION } \\
\text { TIME (D) }\end{array}$ \\
\hline $\begin{array}{c}\text { Jan. } 1993 \\
\text { Jan. } 1992 \\
\end{array}$ & $\begin{array}{l}95.0 \\
107.5 \\
\end{array}$ & $\begin{array}{c}100.5 \\
101.5 \\
\end{array}$ & $\begin{array}{c}1267.5 \\
1287.1 \\
\end{array}$ & $\begin{array}{c}3731.9 \\
4472.9 \\
\end{array}$ & $\begin{array}{r}40.2 \\
45.1 \\
\end{array}$ \\
\hline $\begin{array}{c}\text { Feb. } 1993 \\
\text { Feb. } 1992 \\
\end{array}$ & $\begin{array}{l}71.6 \\
74.8 \\
\end{array}$ & $\begin{array}{l}85.9 \\
88.7 \\
\end{array}$ & $\begin{array}{c}1263.5 \\
1287.8 \\
\end{array}$ & $\begin{array}{c}3594.3 \\
4501.6 \\
\end{array}$ & $\begin{array}{l}44.0 \\
59.0\end{array}$ \\
\hline $\begin{array}{c}\text { Mar. } 1993 \\
\text { Mar. } 1992 \\
\end{array}$ & $\begin{array}{l}57.1 \\
77.0 \\
\end{array}$ & $\begin{array}{l}53.9 \\
92.6 \\
\end{array}$ & $\begin{array}{c}1256.0 \\
1281.4 \\
\end{array}$ & $\begin{array}{c}3329.6 \\
4249.4 \\
\end{array}$ & $\begin{array}{l}67.1 \\
48.4 \\
\end{array}$ \\
\hline $\begin{array}{c}\text { Apr. } 1993 \\
\text { Apr. } 1992 \\
\end{array}$ & $\begin{array}{c}80.4 \\
75.2 \\
\end{array}$ & $\begin{array}{l}48.4 \\
79.3\end{array}$ & $\begin{array}{c}1271.8 \\
1267.9\end{array}$ & $\begin{array}{c}3887.3 \\
3744.9\end{array}$ & $\begin{array}{l}87.1 \\
51.2\end{array}$ \\
\hline $\begin{array}{c}\text { May } 1993 \\
\text { May } 1992\end{array}$ & $\begin{array}{c}132.0 \\
128.6 \\
\end{array}$ & $\begin{array}{c}119.0 \\
112.1 \\
\end{array}$ & $\begin{array}{c}1284.7 \\
1266.4 \\
\end{array}$ & $\begin{array}{c}4375.4 \\
3688.9 \\
\end{array}$ & $\begin{array}{l}39.4 \\
34.4 \\
\end{array}$ \\
\hline $\begin{array}{c}\text { Jun. } 1993 \\
\text { Jun. } 1992\end{array}$ & $\begin{array}{c}100.8 \\
157.3 \\
\end{array}$ & $\begin{array}{c}95.67 \\
131.7 \\
\end{array}$ & $\begin{array}{c}1287.5 \\
1281.1 \\
\end{array}$ & $\begin{array}{r}4487.3 \\
4238.2 \\
\end{array}$ & $\begin{array}{c}49.55 \\
33.7 \\
\end{array}$ \\
\hline Jul._ 1993 & 104.190 .8 & 97.2480 .6 & 1286.41286 .9 & 4444.54454 .2 & 46.962 .1 \\
\hline $\begin{array}{c}\text { Jul. } 1992 \\
\text { Aug. } 1993 \\
\text { Aug. } 1992 \\
\end{array}$ & $\begin{array}{l}87.7 \\
87.8 \\
\end{array}$ & $\begin{array}{l}81.7 \\
81.7 \\
\end{array}$ & $\begin{array}{r}1285.9 \\
1285.9 \\
\end{array}$ & $\begin{array}{c}4422.2 \\
4422.2 \\
\end{array}$ & $\begin{array}{c}56.8 \\
56.8\end{array}$ \\
\hline $\begin{array}{cc}\text { Sept. } & 1993 \\
\text { Sept. } & 1992 \\
\end{array}$ & $\begin{array}{l}67.9 \\
67.9 \\
\end{array}$ & $\begin{array}{l}73.0 \\
73.0 \\
\end{array}$ & $\begin{array}{c}1281.3 \\
1281.3 \\
\end{array}$ & $\begin{array}{c}4242.7 \\
4242.7 \\
\end{array}$ & $\begin{array}{c}61.0 \\
61.0 \\
\end{array}$ \\
\hline $\begin{array}{cc}\text { Oct. } 1993 \\
\text { Oct. } 1992 \\
\end{array}$ & $\begin{array}{c}65.0 \\
76.9 \\
\end{array}$ & $\begin{array}{r}62.5 \\
65.9 \\
\end{array}$ & $\begin{array}{c}1281.2 \\
1284.1 \\
\end{array}$ & $\begin{array}{r}4266.3 \\
4351.0 \\
\end{array}$ & $\begin{array}{l}73.5 \\
69.0 \\
\end{array}$ \\
\hline $\begin{array}{c}\text { Nov. } 1993 \\
\text { Nov. } 1992 \\
\end{array}$ & $\begin{array}{l}77.1 \\
77.8 \\
\end{array}$ & $\begin{array}{l}84.2 \\
81.9 \\
\end{array}$ & $\begin{array}{c}1278.8 \\
1284.2 \\
\end{array}$ & $\begin{array}{c}4150.9 \\
4358.0 \\
\end{array}$ & $\begin{array}{l}51.4 \\
56.3 \\
\end{array}$ \\
\hline $\begin{array}{c}\text { Dec. } 1993 \\
\text { Dec. } 1992\end{array}$ & $\begin{array}{l}86.5 \\
97.6\end{array}$ & $\begin{array}{r}109.9 \\
109.9\end{array}$ & $\begin{array}{c}1273.0 \\
1273.0\end{array}$ & $\begin{array}{c}3930.8 \\
3930.8\end{array}$ & $\begin{array}{l}37.5 \\
37.5\end{array}$ \\
\hline Almmual 119923 & $\begin{array}{l}85 \\
93\end{array}$ & $\begin{array}{l}84 \\
91\end{array}$ & 1281 & 4022 & $\begin{array}{l}55 \\
51\end{array}$ \\
\hline
\end{tabular}




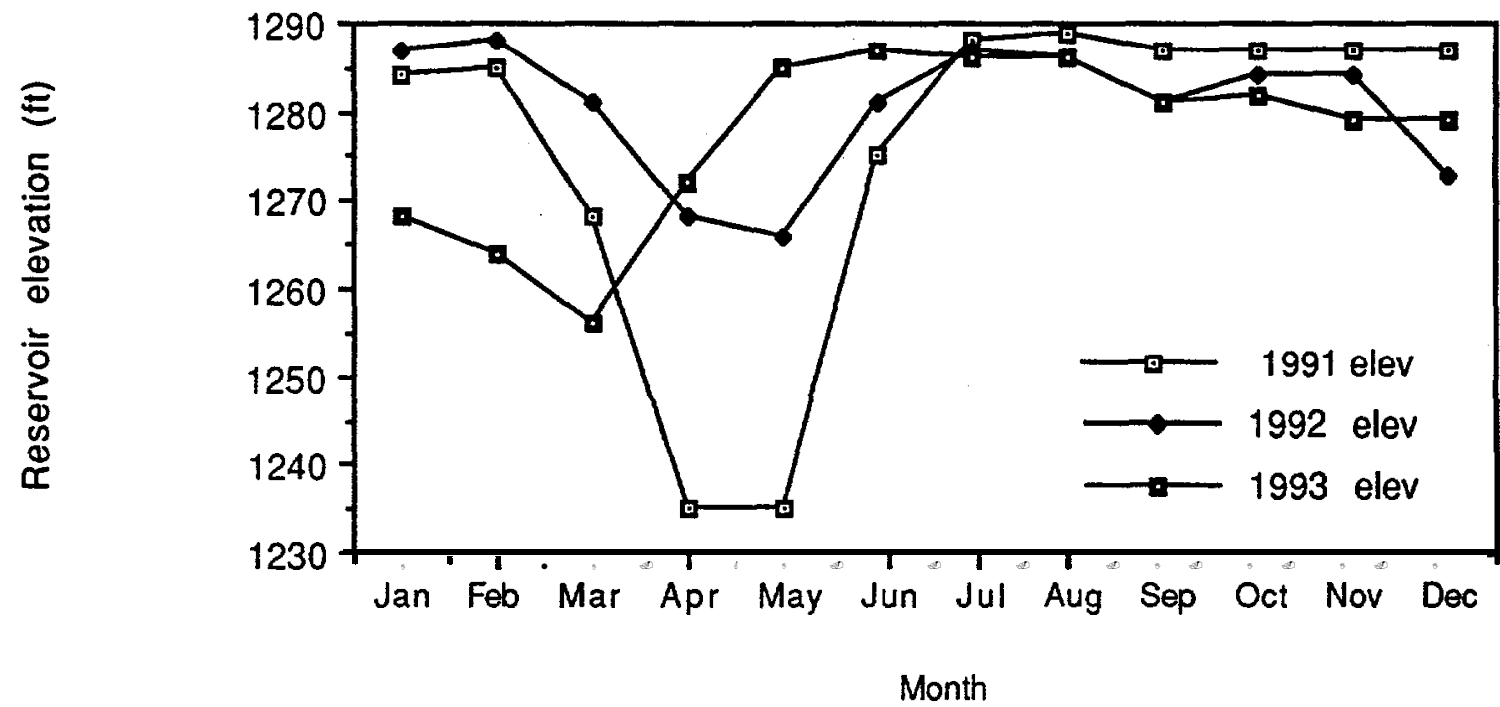

Figure 2. Mean monthly Lake Roosevelt reservoir elevations from 1991 through 1993.

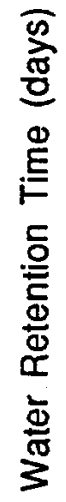

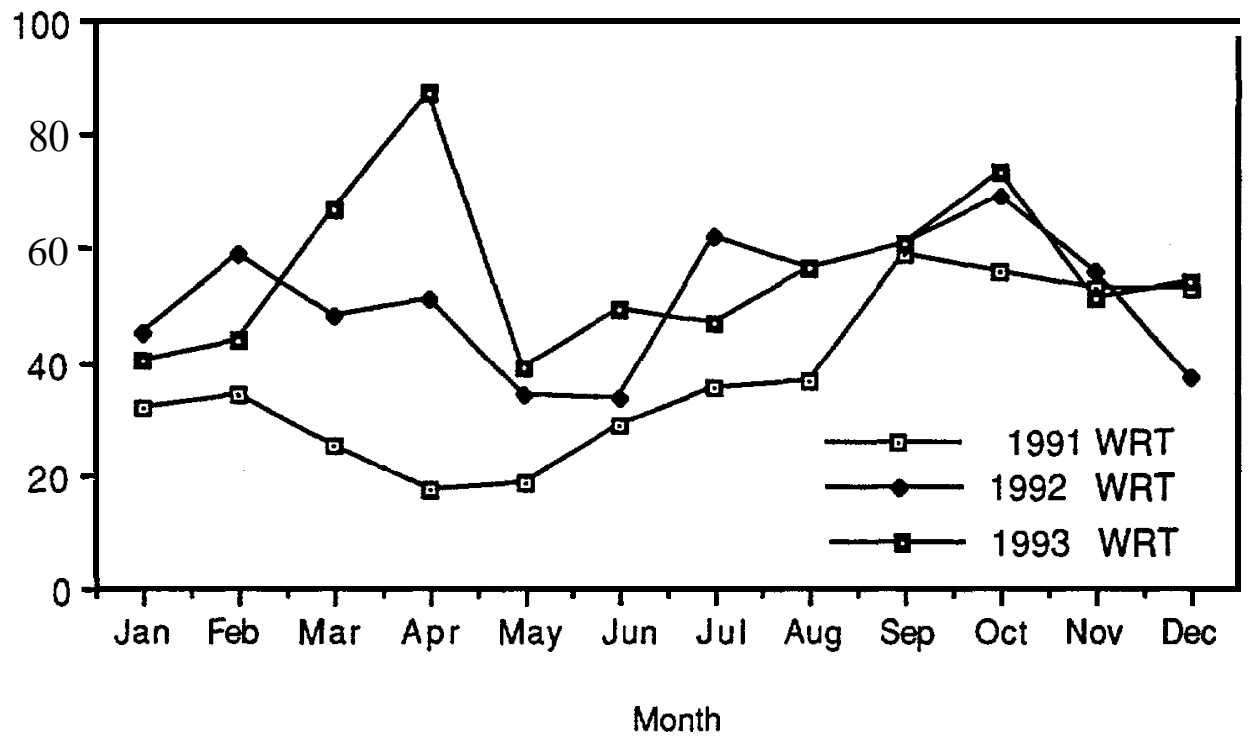

Figure 3. Mean montly Lake Roosevelt water retention time from 1991 through 1993. 


\section{ZOOPLANKTON}

Met hods

Zooplankton samples were collected mid-channel at Gifford, Porcupine Bay, Seven Bays, and Spring Canyon monthly in 1993. Samples were taken using a Wisconsin vertical tow plankton net with an $80 \mu \mathrm{m}$ silk net and bucket. Duplicate tows were made from $33 \mathrm{~m}$ to the surface at each location. Organisms were washed into a $253 \mathrm{ml}$ bottle containing $10 \mathrm{ml}$ of $37 \%$ formaldehyde and $0.5 \mathrm{~g}$ sugar (Rigler 1978). Organisms were stained with $1.0 \mathrm{ml}$ of five percent Lugol's solution and $1.0 \mathrm{ml}$ of saturated eosin-y ethanol stain.

In-the laboratory, zooplankton were identified to species using taxonomic keys of Brandlova et al.(1972), Brooks (1957), Edmondson (1959), Pennak (1978;1989), Ruttner-Kolisko (1974), and Stemberger (1979). A Nikon SMZ- 10 dissecting microscope with a ring illuminator system and Nikon Optiphot phase contrast microscope were used for identification. Three sub-samples were counted using a modified counting chamber (Ward 1955) until 60 organisms or $25 \mathrm{ml}$ of sample were counted (Edmondson and Winberg 1971, Downing and Rigler 1984). Volumes of sub-samples were dependent upon organism densities in the samples.

Density (\# organisms $/ \mathrm{m}^{3}$ ) was calculated using the following sets of equations. Volume of the sample collected by the Wisconsin plankton sampler was calculated with the following formula:

$$
\mathrm{V}=\Pi \mathrm{r}^{2} \mathrm{~h}
$$

where:

$$
\begin{aligned}
\mathrm{V} & =\text { volume of the sample; } \\
\Pi & =\text { pi (3.14); } \\
\mathrm{r} & =\text { radius of sampler, and } \\
\mathrm{h} & =\text { depth of sample. }
\end{aligned}
$$

Microcrustacean zooplankton density (\# organisms/ $\mathrm{m}^{3}$ ) was calculated with the following equation: 


$$
\begin{aligned}
\mathrm{D} & =\mathrm{DF} * 1000 \\
\text { where: } \quad \mathrm{D} & =\text { density }\left(\# \text { organisms } / \mathrm{m}^{3}\right) ; \\
\mathrm{Sn} & =\text { number of sub-samples; } \\
\mathrm{s} \mathrm{v} & =\text { sample volume; } \\
\mathrm{s} \mathrm{s} \mathrm{v} & =\text { sub-sample volume; } \\
\mathrm{V} & =\text { volume of entire sample; } \\
\mathrm{DF} & =\text { dilution factor; and } \\
\mathrm{Tc} & =\text { total number counted of each species } \\
&
\end{aligned}
$$

Predominant cladocerans were randomly chosen and measured from the top of the head to the base of the carapace, excluding the spine. Cladocera biomass was determined using length-weight regression equations summarized by Downing and Rigler (1984).

Results and Discussion

\section{Zooplankton Densities}

A total of 38 species of zooplankton were identified in Lake Roosevelt during 1993 (Table 3). Phylum Rotifera were not enumerated. Fifteen species were identified from Order Plioma, the most diverse group, followed by Order Cladocera with 14 species, and 6 species were identified from Order Eucopepoda.

Monthly mean densities $\left(\# / \mathrm{m}^{3}\right)$ of microcrustacean zooplankton collected at Gifford, Porcupine Bay, Seven Bays, and Spring Canyon are shown in Tables 4 through 7. Mean density/species for each location are located in Appendix B.

Mean total zooplankton densities at Gifford ranged from $8.04 / \mathrm{m}^{3}$ in April to $6,942.59 / \mathrm{m}^{3}$ in September with an annual mean of $907.86 \mathrm{~m}^{3}$. Mean total zooplankton densities at Porcupine Bay ranged from $24.13 / \mathrm{m}^{3}$ in April to $6912.79 / \mathrm{m}^{3}$ in February with an annual mean of $1217.6 / \mathrm{m}^{3}$. Mean total zooplankton densities at Seven Bays ranged from $28.16 / \mathrm{m}^{3}$ in December to $9594.47 / \mathrm{m}^{3}$ in August with an annual mean of $2031.33 / \mathrm{m}^{3}$. Mean total zooplankton densities at Spring Canyon ranged from $50.94 / \mathrm{m}^{3}$ in October to $5750.72 / \mathrm{m}^{3}$ in June with an annual mean of $1184.93 / \mathrm{m}^{3}$. 
Table 3.

Synoptic list of zooplankton taxa identified in Lake Roosevelt during the 1993 study period.

\author{
Phylum Anthropoda \\ Class Crustacea \\ Subclass Brachiopoda \\ Order Cladocera \\ Family Daphnidae \\ 1. Ceriodaphnia quadranqula \\ 2. Daphnia galeata mendotae \\ 3. Daphnia retrocurva \\ 4. Daphnia schødleri \\ 5. Daphnia thorata \\ 6. Simocephalus serrulatus \\ Family Chydoridae \\ 7. Alona guttata \\ 8. Alona quadrangularis \\ 9. Chydorus sphaericus \\ Family Sididae \\ 10. Diaphanosoma brachyurum \\ 11. Diaphanosoma birgei \\ 12. Sida crystallina \\ Family Bosminidae \\ 13. Bosmina longirostris \\ Family Leptodoriidae \\ Subclass Copepoda \\ 14. Leptodora kindti \\ Order Eucopepoda \\ Suborder Calanoida \\ FamilyDiaptomidae \\ 15. Leptodiaptomus ashlandi \\ 16.Skistodiaptomus oregonensis \\ Family Temoridae \\ 17. Epischura nevadensis \\ Suborder Cyclopoida \\ Family Cyclopoidae \\ 18. Diacyclops bicuspidatus thomasi \\ 19. Mesocyclop edax \\ Suborder Harpacticoida \\ Family Harpacticoidae \\ 20. Bryocamptus spp.
}

\author{
Phylum Rotifera \\ Class Monogonon ta \\ Order Flosculariacea \\ Family Conochilidae \\ 21. Conochilus unicornis \\ Family Testudinellidae \\ 22. Testudinella spp. \\ Family Filiniidae \\ 23. Filinia terminalis \\ Order Plioma \\ Family Synchaetidae \\ 24. Pleosoma truncatum \\ 25. Polyarthra spp. \\ 26. Synchaeta pectinata \\ Family Asplanchnidae \\ 27. Asplanchna herricki \\ 28. Asplanchna priodonta \\ Family Brachionidae \\ 29. Brachionus quadridentata \\ 30. Kellicottia longispina \\ 31 Keratella spp. \\ 32. Notholca spp. \\ Family Epiphanidae \\ 3 3. Epiphanes spp. \\ Family Euchlanidae \\ 34. Euchlanis dilatata \\ 35.Euchlanis triquetra \\ Family Trichotriidae \\ 36. Trichotria tetractis \\ Family Trichocercidae \\ 37. Trichocerca spp. \\ Family Lecanidae \\ 38. Monostyla lunaris
}


Table 4. , Mean monthly density values $\left(\# / \mathbf{m}^{\mathbf{3}}\right)$ and standard deviations of different categories of zooplankton at Gifford (Index Station 2) in 1993.

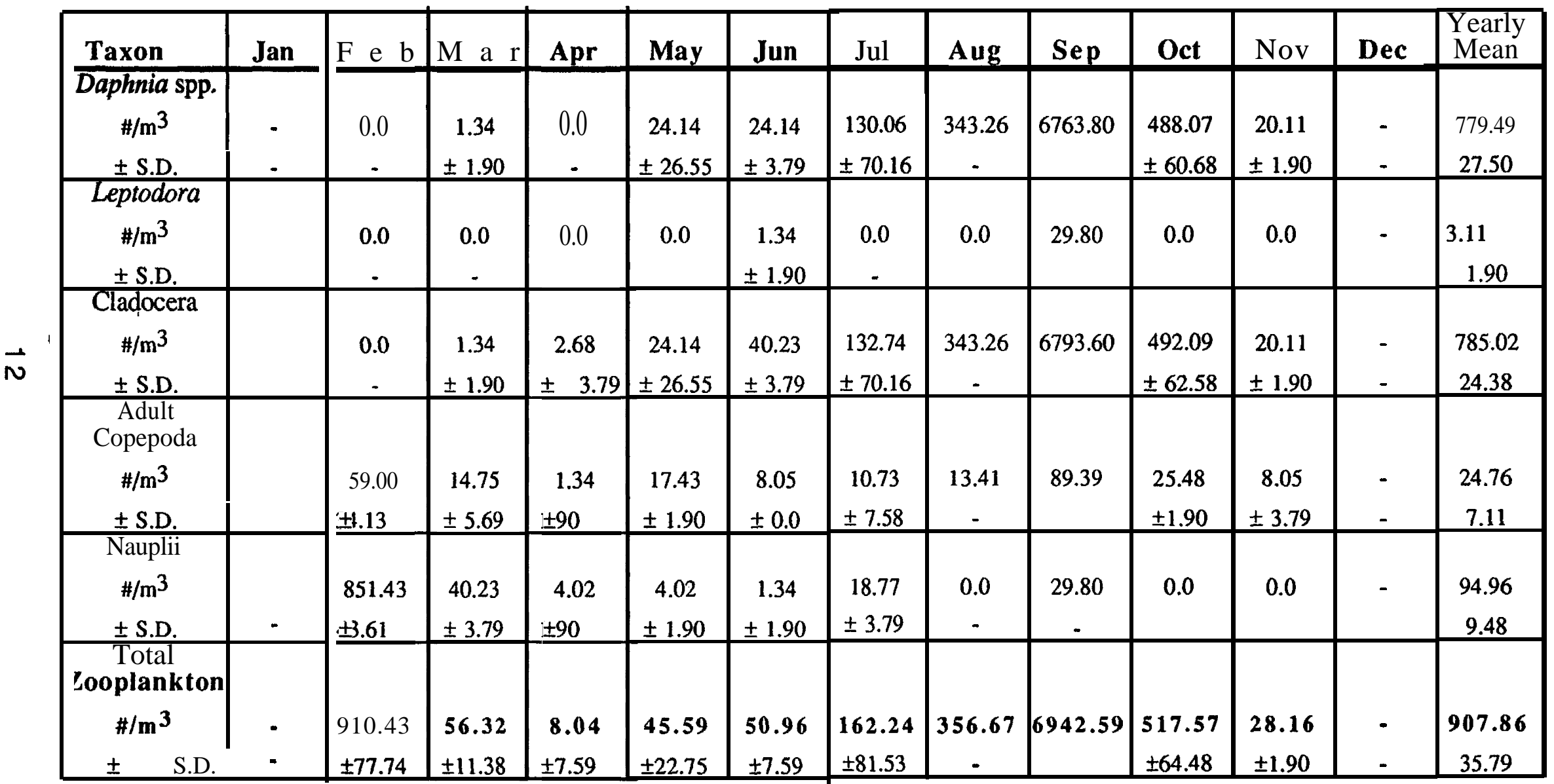

- represents no samples were collected). 
Table 5. $\quad$ Mean monthly density values $\left(\# / \mathbf{m}^{\mathbf{3}}\right)$ and standard deviations of different categories of zooplankton at Porcupine Bay (Index Station 4) in 1993.

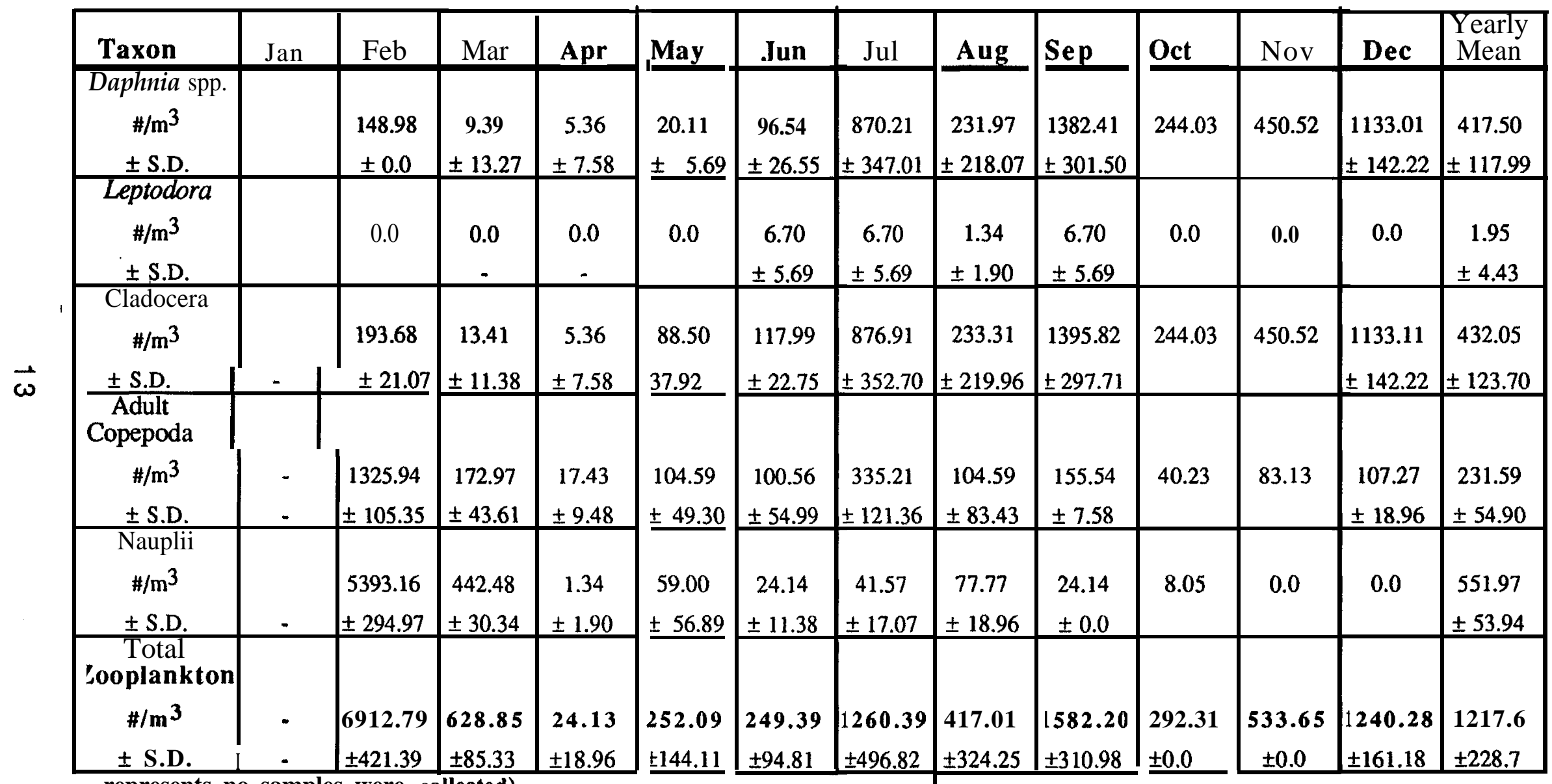

- represents no samples were collected). 
Table 6. ' Mean monthly density values $\left(\# / \mathbf{m}^{\mathbf{3}}\right)$ and standard deviations of different categories of zooplankton at Seven Bays (Index Station 6) in 1993.

\begin{tabular}{|c|c|c|c|c|c|c|c|c|c|c|c|c|c|}
\hline Taxon & Jan & Feb & Mar & Apr & May & Jun & Jul & Aug & Sep & Oct & Nov & Dec & $\begin{array}{l}\text { Yearly } \\
\text { M e a n }\end{array}$ \\
\hline $\begin{array}{c}\text { Leptodora } \\
\# / \mathrm{m}^{3} \\
\text { S.D. }\end{array}$ & - & $\begin{array}{l}0.0 \\
. \\
\end{array}$ & 0.0 & $\begin{array}{c}0.0 \\
- \\
\end{array}$ & 0.0 & $\begin{array}{r}42.91 \\
\pm 11.38 \\
\end{array}$ & 0.0 & $\begin{array}{r}74.49 \\
\pm 21.07 \\
\end{array}$ & - & 0.0 & - & 0.0 & $\begin{array}{r}13.04 \pm \\
\pm 16.23 \\
\end{array}$ \\
\hline $\begin{array}{c}\text { Cladocera } \\
\# / \mathrm{m}^{3} \\
\pm \text { S.D. } \\
\end{array}$ & - & $\begin{array}{r}25.48 \\
\pm 5.69 \\
\end{array}$ & $\begin{array}{r}5.36 \\
\pm 3.79 \\
\end{array}$ & $\begin{array}{r}9.39 \\
+13.27 \\
\end{array}$ & $\begin{array}{r}611.42 \\
\pm 41.72 \\
\end{array}$ & $\begin{array}{r}1153.12 \\
\pm 72.06 \\
\end{array}$ & $\begin{array}{r}2988.14 \\
-2811.28 \\
\end{array}$ & $\begin{array}{r}8268.53 \\
\pm 1369.5 \mathrm{C} \\
\end{array}$ & & 1185.30 & & $\begin{array}{r}16.09 \\
+7.58 \\
\end{array}$ & $\begin{array}{r}1584.76 \\
\pm 540.61 \\
\end{array}$ \\
\hline $\begin{array}{c}\text { Adult } \\
\text { Copepoda } \\
\# / \mathrm{m}^{3} \\
\pm \text { S.D. } \\
\end{array}$ & & $\begin{array}{r}122.02 \\
\pm 17.07 \\
\end{array}$ & $\begin{array}{r}87.15 \\
\pm 5.69 \\
\end{array}$ & $\begin{array}{c}20.11 \\
\pm 1.90 \\
\end{array}$ & $\begin{array}{r}305.71 \\
\pm 3.79 \\
\end{array}$ & $\begin{array}{r}281.58 \\
\pm 94.81 \\
\end{array}$ & $\begin{array}{r}174.66 \\
\pm 174.66 \\
\end{array}$ & $\begin{array}{r}387.35 \\
\pm 84.28 \\
\end{array}$ & - & 337.89 & - & $\begin{array}{r}12.07 \\
\pm 5.69 \\
\end{array}$ & $\begin{array}{r}192.04 \\
\pm 48.49 \\
\end{array}$ \\
\hline $\begin{array}{c}\text { Nauplii } \\
\quad \# / \mathrm{m}^{3} \\
\pm \text { S.D. } \\
\end{array}$ & - & $\begin{array}{l}540.36 \\
\pm 32.24 \\
\end{array}$ & $\begin{array}{r}533.66 \\
\pm 41.72 \\
\end{array}$ & $\begin{array}{r}61.68 \\
+22.75 \\
\end{array}$ & $\begin{array}{c}79.11 \\
\pm 36.03\end{array}$ & $\begin{array}{r}32.18 \\
\pm 30.34\end{array}$ & $\begin{array}{c}62.27 \\
\pm 80.48\end{array}$ & $\begin{array}{c}864.10 \\
\pm 210.69\end{array}$ & & 0.0 & - & 0.0 & $\begin{array}{r}241.48 \\
\pm 64.89\end{array}$ \\
\hline \begin{tabular}{|l|} 
Total \\
Looplank \\
$\# / \mathbf{m}^{\mathbf{3}}$ \\
\pm S.D.
\end{tabular} & - & $\begin{array}{c}687.86 \\
\pm 55.00 \\
\end{array}$ & $\begin{array}{r}626.17 \\
+51.20 \\
\end{array}$ & $\begin{array}{r}91.18 \\
+37.92 \\
\end{array}$ & $\begin{array}{c}996.25 \\
\pm 81.54 \\
\end{array}$ & $\begin{array}{l}1509.79 \\
\pm 208.59\end{array}$ & $\begin{array}{r}3224.87 \\
-3066.42\end{array}$ & $\begin{array}{r}9594.47 \\
\pm 1685.54\end{array}$ & - & $\begin{array}{c}1523.19 \\
.\end{array}$ & - & $\begin{array}{r}28.16 \\
\pm 13.27 \\
\end{array}$ & $\begin{array}{r}2031.33 \\
\pm 649.94 \\
\end{array}$ \\
\hline
\end{tabular}


Table 7. , Mean monthly density values $\left(\# / \mathbf{m}^{\mathbf{3}}\right)$ and standard deviations of different categories of zooplankton at Spring Canyon (Index Station 9) in 1993.

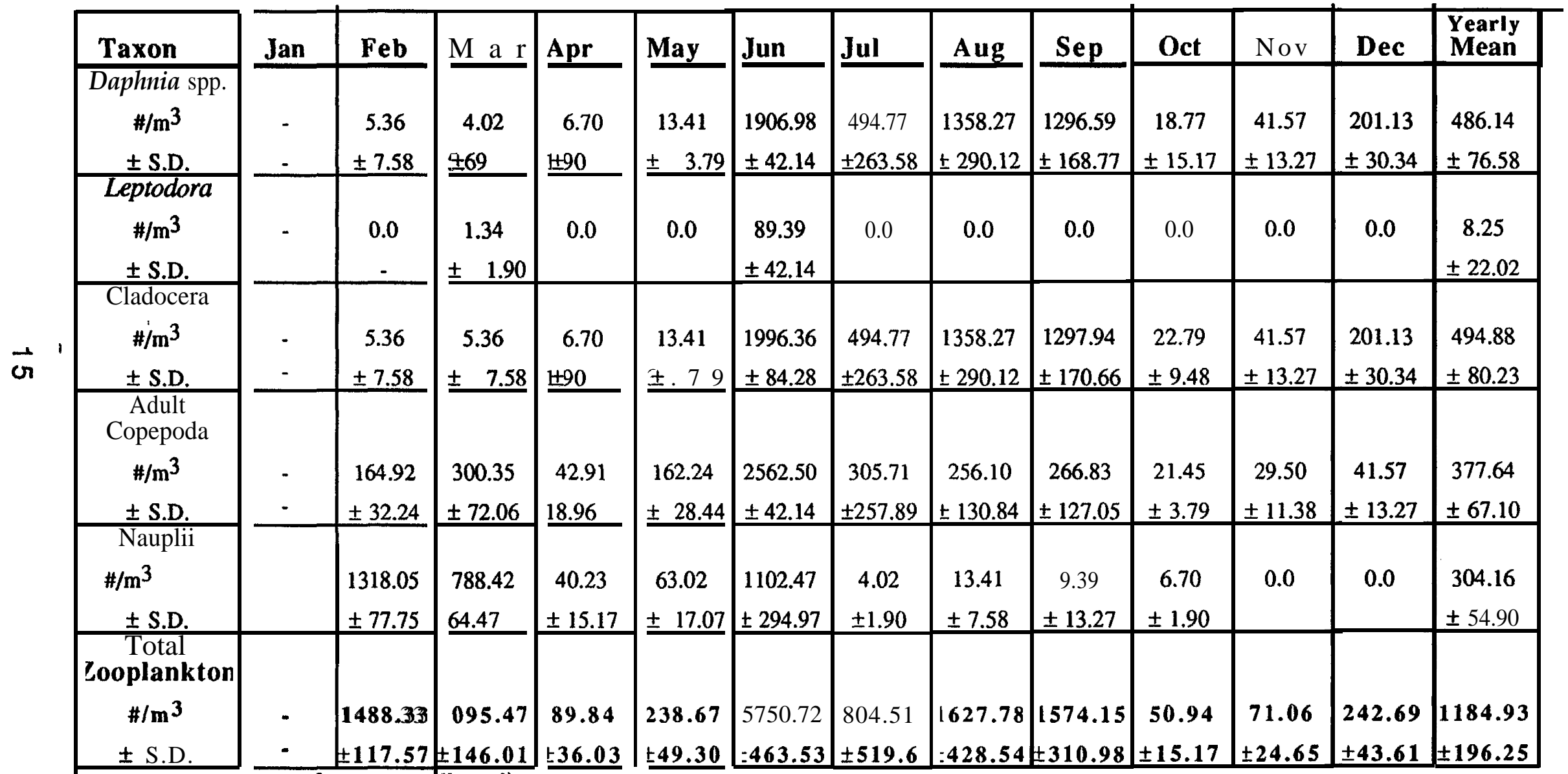

- represents no samples were collected). 
The reservoir experienced two peaks of daphnia spp. densities. The first peak occurred between January and March due to nutrients and stable water retention times. The second peak occurred between May and October as the reservoir was filling which provided a large quantity of nutrients for phytoplankton which increased the forage base for zooplankton. There was a considerable difference in densities of zooplankton among the areas (Figures 4 and 5). Highest recorded daphnia spp. was 8,194/ $\mathrm{m}^{3}$ at Seven Bays in August. Seven Bays also had the highest total zooplankton density in August at $9564 / \mathrm{m}^{3}$. The higher density values at the lower end of the reservoir may be explained by the flushing of water through the reservoir.

Figures 6 and 7 show water retention times and densities for the past three years at Porcupine Bay and Seven Bays. At Porcupine Bay, in 1991 densities in spring peaked dramatically while the water retention times remained low.

Declining pool elevation and large releases from the dam may cause extreme downstream loss of zooplankton. When zooplankton are circulated deep into the water column, deep drawdowns in the winter should increase the downstream loss of this valuable fish food resource.

\section{Zooplankton Biomass}

Monthly mean biomass $\left(\mathrm{mg} / \mathrm{m}^{3}\right)$ values of microcrustacean zooplankton collected at Gifford, Porcupine Bay, Seven Bays, and Spring Canyon are shown in Tables 8 through 11. Mean biomass/species for each location can be found in Appendix B. Total zooplankton biomass at Gifford averaged $7.14 \mathrm{mg} / \mathrm{m}^{3}$ for the year, Total zooplankton biomass at Porcupine Bay averaged $8.18 \mathrm{mg} / \mathrm{m}^{3}$ for the year. Total zooplankton biomass at Seven Bays averaged $50.09 \mathrm{mg} / \mathrm{m}^{3}$ for the year. Total zooplankton biomass at Spring Canyon averaged $16.01 \mathrm{mg} / \mathrm{m}^{3}$ for the year.

\section{Zooplankton Lengths}

Monthly mean lengths (mm) of microcrustacean zooplankton collected at Gifford, Porcupine Bay, Seven Bays, and Spring Canyon are shown in Tables 12 through 15. Length ranges and mean lengths/species for each location are located in Appendix B.

Yearly mean lengths of cladocera at Gifford are: Daphnia galeata mendbtae - 1.09 mm; Daphnia retrocurva - 1.29 mm; Daphnia sch $\phi d l e r i-1.06$ mm; Daphnia thorata - 1.26 


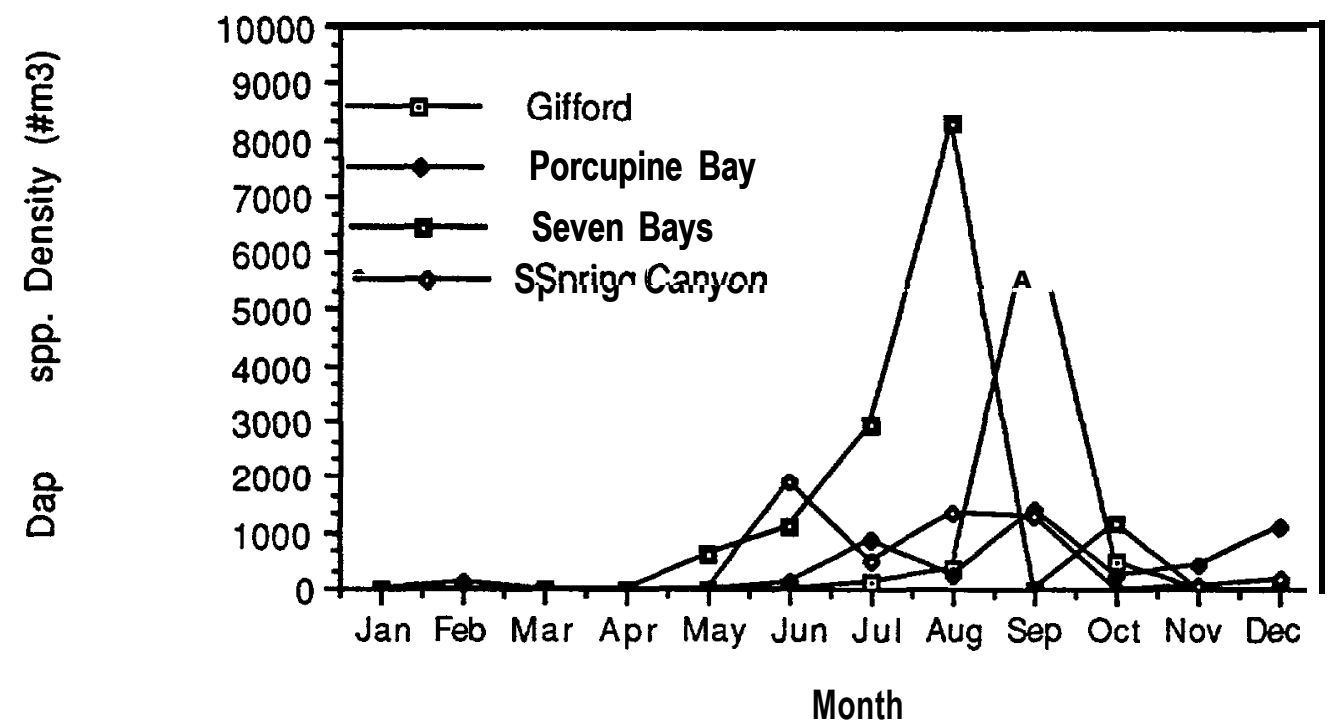

Figure 4. Mean monthly Daphnia spp. density $\left(\#^{3}{ }^{3}\right.$ at Gifford, Porcupine Bay, Seven Bays, and Spring Canyon in 1993.

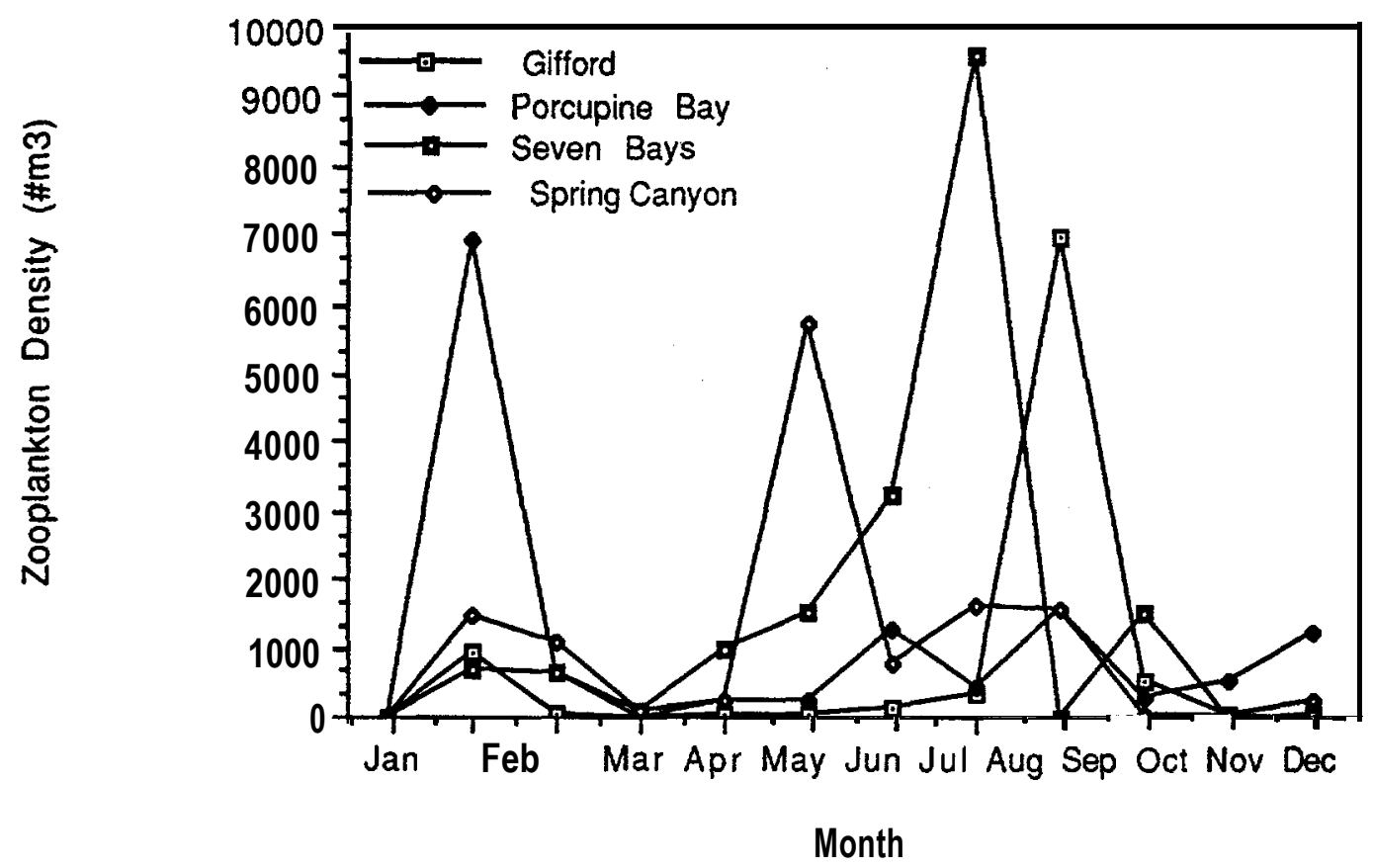

Figure 5. Mean monthly zooplankton density $\left(\#^{3}\right.$ ) at Gifford, Porcupine Bay, Seven Bays, and Spring Canyon in 1993. 


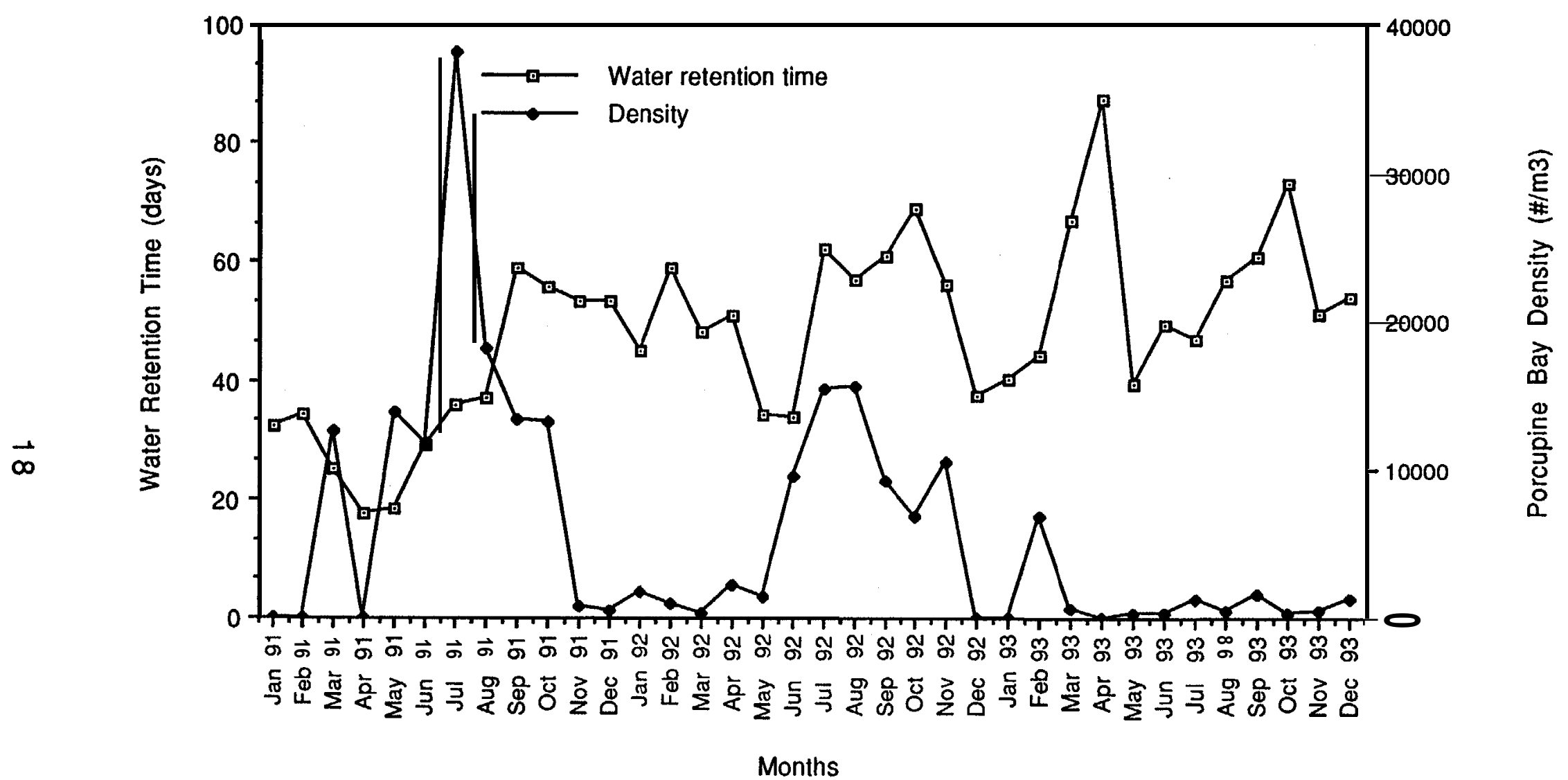

Figure 6. Density and water retention times at Porcupine Bay from 1991 through 1993. 


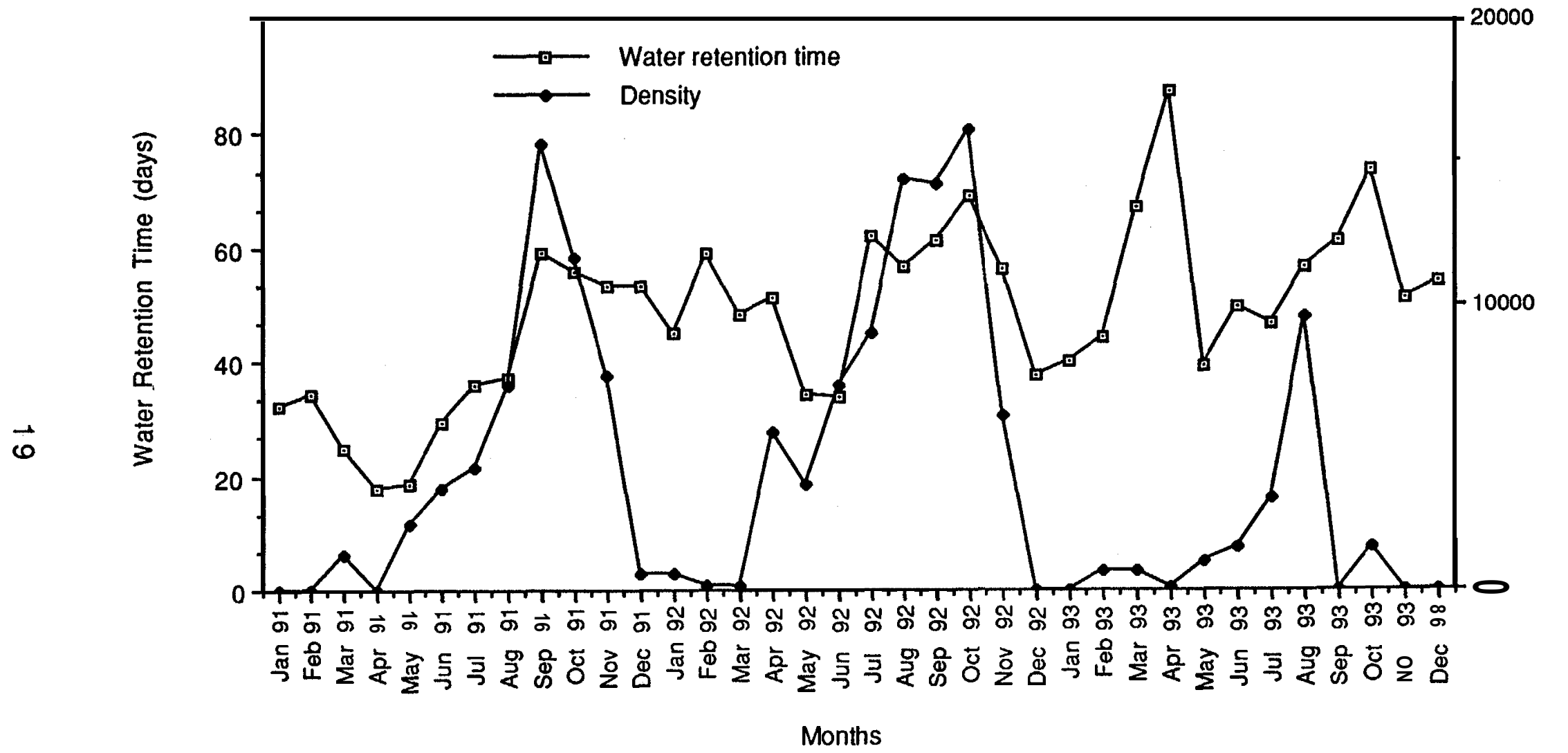

命

Figure 7. Density and water retention times at Seven Bays from 1991 through 1993. 
Table 8. Mean monthly biomass values $\left(\mathbf{m g} / \mathbf{m}^{\mathbf{3}}\right)$ of different Cladocera at Gifford (Index Station 2) in 1993.

\begin{tabular}{|c|c|c|c|}
\hline & $\begin{array}{c}\text { Daphnia spp. } \\
\mu \mathrm{g} / \mathrm{m}^{3}\end{array}$ & $\begin{array}{c}\text { Leptodora kindti } \\
\mu \mathrm{g} / \mathrm{m}^{3}\end{array}$ & $\begin{array}{c}\text { Total Cladocera } \\
\mu \mathrm{g} / \mathrm{m}^{3}\end{array}$ \\
\hline Jan. & - & - & - \\
\hline Feb. & - & - & - \\
\hline Mar. & 0.004 & 0.0 & 0.004 \\
\hline Apr. & - & - & - \\
\hline May & 0.092 & 0.0 & 0.092 \\
\hline Jun. & 0.257 & 0.355 & 0.613 \\
\hline Jul. & 1.054 & 0.0 & 1.054 \\
\hline Aug. & 1.570 & 0.0 & 1.570 \\
\hline Sep. & 56.368 & 0.963 & 57.331 \\
\hline Oct. & 10.244 & 0.0 & 10.244 \\
\hline Nov. & 0.536 & 0.0 & 0.536 \\
\hline Dec. & - & - & - \\
\hline Yearly Mean & $\mathbf{7 . 0 1 3}$ & $\mathbf{0 . 1 3 2}$ & 7.144 \\
\hline
\end{tabular}

Table 9.

Mean monthly biomass values $\left(\mathbf{m g} / \mathbf{m}^{\mathbf{3}}\right)$ of different Cladocera at Porcupine Bay (Index Station 4) in 1993.

\begin{tabular}{|c|c|c|c|}
\hline & $\begin{array}{c}\text { Daphnia spp. } \\
\mu \mathrm{g} / \mathrm{m}^{3}\end{array}$ & $\begin{array}{c}\text { Leptodora kindti } \\
\mu \mathrm{g} / \mathrm{m}^{3}\end{array}$ & $\begin{array}{c}\text { Total Cladocera } \\
\mu \mathrm{g} / \mathrm{m}^{3}\end{array}$ \\
\hline Jan. & - & - & - \\
\hline Feb. & 1.198 & 0.0 & 1.198 \\
\hline Mar. & 0.084 & 0.0 & 0.084 \\
\hline Apr. & 0.039 & 0.0 & 0.039 \\
\hline May & 0.135 & 0.0 & 0.135 \\
\hline Jun. & 0.721 & 0.184 & 0.904 \\
\hline Jul. & 13.471 & 0.532 & 14.002 \\
\hline Aug. & 1.869 & 0.011 & 1.880 \\
\hline Sep. & 15.379 & 0.228 & 15.607 \\
\hline Oct. & 13.146 & 0.0 & 13.146 \\
\hline Nov. & 19.040 & 0.0 & 19.040 \\
\hline Dec. & 23.971 & 0.0 & 23.971 \\
\hline Yearly Mean & $\mathbf{8 . 0 9 6}$ & 0.087 & $\mathbf{8 . 1 8 2}$ \\
\hline
\end{tabular}

(- represents no samples were collected). 
Table 10. Mean monthly biomass values $\left(\mathbf{m g} / \mathbf{m}^{\mathbf{3}}\right)$ of different Cladocera at Seven Bays (Index Station 6) in 1993.

\begin{tabular}{|c|c|c|c|}
\hline & $\begin{array}{c}\text { Daphnia spp. } \\
\mu \mathrm{g} / \mathrm{m}^{3}\end{array}$ & $\begin{array}{c}\text { Leptodora kindti } \\
\mu \mathrm{g} / \mathrm{m}^{3}\end{array}$ & $\begin{array}{c}\text { Total Cladocera } \\
\mu \mathrm{g} / \mathrm{m}^{3}\end{array}$ \\
\hline Jan. & - & - & - \\
\hline Feb. & 0.319 & 0.0 & 0.319 \\
\hline Mar. & 0.139 & 0.0 & 0.139 \\
\hline Apr. & 0.027 & 0.0 & 0.027 \\
\hline May & 10.132 & 0.0 & 10.132 \\
\hline Jun. & 18.112 & 1.307 & 19.419 \\
\hline Jul. & 31.059 & 0.0 & 31.059 \\
\hline Aug. & 294.987 & 3.361 & 298.348 \\
\hline Sep. & - & - & - \\
\hline Oct. & 41.472 & 0.0 & 41.475 \\
\hline Nov. & - & - & - \\
\hline Dec. & 0.149 & 0.0 & 0.149 \\
\hline Yearly Mean & $\mathbf{4 9 . 5 1}$ & $\mathbf{0 . 5 8}$ & $\mathbf{5 0 . 0 9}$ \\
\hline
\end{tabular}

Table 11. Mean monthly biomass values $\left(\mathbf{m g} / \mathbf{m}^{\mathbf{3}}\right)$ of different Cladocera at Spring Canyon (Index Station 9) in 1993.

\begin{tabular}{|c|c|c|c|}
\hline & $\begin{array}{c}\text { Daphnia spp. } \\
\mu \mathrm{g} / \mathrm{m}^{3}\end{array}$ & $\begin{array}{c}\text { Leptodora kindt } \mathrm{T} \text { } \\
\mu \mathrm{g} / \mathrm{m}^{3}\end{array}$ & $\begin{array}{c}\text { Total Cladocera } \\
\mu \mathrm{g} / \mathrm{m}^{3}\end{array}$ \\
\hline Jan. & - & - & - \\
\hline Feb. & 0.038 & 0.0 & 0.038 \\
\hline Mar. & 0.018 & 0.0 & 0.018 \\
\hline Apr. & 0.103 & 0.0 & 0.103 \\
\hline May & 0.262 & 0.0 & 0.262 \\
\hline Jun. & 83.965 & 16.026 & 99.991 \\
\hline Jul. & 6.695 & 0.0 & 6.695 \\
\hline Aug. & 26.066 & 0.0 & 26.066 \\
\hline Sep. & 36.077 & 0.0 & 36.077 \\
\hline Oct. & 0.426 & 0.0 & 0.426 \\
\hline Nov. & 1.143 & 0.0 & 0.143 \\
\hline Dec. & 5.334 & 0.0 & 5.334 \\
\hline Yearly Mean & 14.56 & 1.46 & 16.01 \\
\hline
\end{tabular}

(- represents no samples were collected). 
Table 12. Mean monthly size values $(\mathrm{mm})( \pm$ S.D. $)$ of different Cladocera species at Gifford (Index Station 2) in 1993.

\begin{tabular}{|c|c|c|c|c|c|}
\hline & $\begin{array}{l}\text { D. galeata } \\
\text { mendotae } \\
(\mathrm{mm})\end{array}$ & $\begin{array}{l}\text { Daphnia } \\
\text { retrocurva } \\
\text { (mm) }\end{array}$ & $\begin{array}{l}\text { Daphnia } \\
\text { schødleri } \\
\text { (mm) }\end{array}$ & $\begin{array}{c}\text { Daphnia } \\
\text { thorata } \\
\text { (mm) }\end{array}$ & $\begin{array}{l}\text { Leptodora } \\
\text { kindti } \\
\text { (mm) }\end{array}$ \\
\hline $\begin{array}{l}\text { Jan. } \\
\pm \text { S.D. }\end{array}$ & - & $E$ & - & - & $=$ \\
\hline $\begin{array}{l}\text { Feb. } \\
\pm \text { S.D. }\end{array}$ & - & $=$ & - & 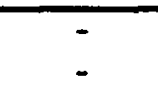 & - \\
\hline $\begin{array}{l}\text { Mar. } \\
\pm \text { S.D. }\end{array}$ & $\begin{array}{c}1.40 \\
-\end{array}$ & - & - & - & - \\
\hline $\begin{array}{c}\text { Apr. } \\
\pm \text { S.D. }\end{array}$ & 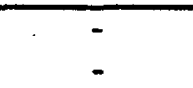 & $=$ & - & - & - \\
\hline $\begin{array}{c}\text { May } \\
\pm \text { S.D. }\end{array}$ & - & - & $\begin{array}{l}0.73 \\
0.17\end{array}$ & - & - \\
\hline $\begin{array}{c}\text { Jun. } \\
\pm \text { S.D. }\end{array}$ & $\begin{array}{c}0.95 \\
\pm 0.21\end{array}$ & $\begin{array}{c}0.98 \\
-\end{array}$ & $\begin{array}{c}1.06 \\
\pm 0.29\end{array}$ & $\begin{array}{c}0.90 \\
0.0\end{array}$ & $\begin{array}{c}11.00 \\
-\end{array}$ \\
\hline $\begin{array}{c}\text { Jul. } \\
\pm \text { S.D. }\end{array}$ & $\begin{array}{c}0.93 \\
\pm 0.05\end{array}$ & $\begin{array}{c}1.14 \\
\pm 0.23\end{array}$ & $\begin{array}{c}0.94 \\
\pm 0.21\end{array}$ & $\begin{array}{c}1.41 \\
\pm 0.27\end{array}$ & \\
\hline $\begin{array}{l}\text { Aug. } \\
\pm \text { S.D. }\end{array}$ & $\begin{array}{c}0.71 \\
\pm 0.08\end{array}$ & - & $\begin{array}{c}0.79 \\
\pm 0.17\end{array}$ & - & - \\
\hline $\begin{array}{l}\text { Sep. } \\
\pm \text { S.D. }\end{array}$ & $\begin{array}{c}0.99 \\
\pm 0.16\end{array}$ & $\begin{array}{c}1.64 \\
\pm 0.17\end{array}$ & $\begin{array}{c}1.07 \\
\pm 0.22\end{array}$ & $\begin{array}{c}1.35 \\
\pm 0.31\end{array}$ & 5.00 \\
\hline $\begin{array}{r}\text { Oct. } \\
\pm \text { S.D. } \\
\end{array}$ & $\begin{array}{r}1.40 \\
\pm 0.25 \\
\end{array}$ & $\begin{array}{r}1.46 \\
\pm 0.0\end{array}$ & $\begin{array}{c}1.42 \\
\pm 0.19\end{array}$ & $\begin{array}{c}1.38 \\
\pm 0.27\end{array}$ & $\overline{-}$ \\
\hline $\begin{array}{l}\text { Nov. } \\
\pm \text { S.D. }\end{array}$ & $\begin{array}{c}1.27 \\
\pm 0.47\end{array}$ & - & $\begin{array}{c}1.42 \\
\pm 0.44\end{array}$ & - & $\overline{-}$ \\
\hline $\begin{array}{l}\text { Dec. } \\
\pm \text { S.D. }\end{array}$ & - & - & - & 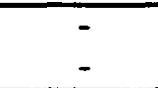 & 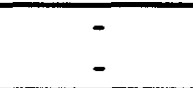 \\
\hline $\begin{array}{l}\text { Yearly } \\
\text { Mean }\end{array}$ & 1.09 & 1.29 & 1.06 & 1.26 & 8.0 \\
\hline
\end{tabular}

(- indicates no data were obtained due to lack of sample or organisms in sample.) 
Table 13. Mean monthly size values $(\mathrm{mm})( \pm$ S.D.) of different Cladocera species at Porcupine Bay (Index Station 4) in 1993.

\begin{tabular}{|c|c|c|c|c|c|}
\hline & $\begin{array}{l}\text { D. galeata } \\
\text { mendotae } \\
(\mathrm{mm})\end{array}$ & $\begin{array}{l}\text { Daphnia } \\
\text { retrocurva } \\
\text { (mm) }\end{array}$ & $\begin{array}{l}\text { Daphnia } \\
\text { schodleri } \\
\text { (mm) }\end{array}$ & $\begin{array}{c}\text { Daphnia } \\
\text { thorata } \\
\text { (mm) }\end{array}$ & $\begin{array}{c}\text { Leptodora } \\
\text { kindti } \\
\text { (mm) }\end{array}$ \\
\hline $\begin{array}{c}\text { Jan. } \\
\pm \text { S.D. } \\
\end{array}$ & & & & & \\
\hline $\begin{array}{l}\text { Feb. } \\
\pm \text { S.D. }\end{array}$ & & & $\begin{array}{c}0.93 \\
\pm 0.14\end{array}$ & & \\
\hline $\begin{array}{c}\text { Mar. } \\
\pm \text { S.D. }\end{array}$ & $\begin{array}{c}1.18 \\
\pm 0.13\end{array}$ & - & $\begin{array}{c}0.82 \\
\pm 0.0\end{array}$ & $\begin{array}{c}1.20 \\
\pm 0.0\end{array}$ & \\
\hline $\begin{array}{c}\text { Apr. } \\
\pm \text { S.D. }\end{array}$ & & & $\begin{array}{c}0.90 \\
\pm 0.12\end{array}$ & & \\
\hline $\begin{array}{l}\text { May } \\
\pm \text { S.D. }\end{array}$ & $\begin{array}{c}1.08 \\
\pm 0.24\end{array}$ & $\begin{array}{c}1.04 \\
\pm 0.12\end{array}$ & $\begin{array}{c}0.95 \\
\pm 0.10\end{array}$ & $\begin{array}{c}1.22 \\
\pm 0.0\end{array}$ & \\
\hline $\begin{array}{c}\text { Jun. } \\
\pm \text { S.D. }\end{array}$ & $\begin{array}{c}1.05 \\
\pm 0.14\end{array}$ & $\begin{array}{c}1.11 \\
\pm 0.29\end{array}$ & $\begin{array}{c}1.06 \\
\pm 0.18\end{array}$ & $\begin{array}{r}1.16 \\
\pm 0.0\end{array}$ & $\begin{array}{c}4.70 \\
\pm 2.20\end{array}$ \\
\hline $\begin{array}{c}\text { Jul. } \\
\pm \text { S.D. }\end{array}$ & $\begin{array}{c}1.60 \\
\pm 0.42\end{array}$ & $\begin{array}{c}1.37 \\
\pm 0.38\end{array}$ & $\begin{array}{c}1.33 \\
\pm 0.35\end{array}$ & $\begin{array}{c}1.33 \\
\pm 0.36\end{array}$ & $\begin{array}{c}7.00 \\
\pm 2.83\end{array}$ \\
\hline $\begin{array}{r}\text { Aug. } \\
\pm \text { S.D. }\end{array}$ & $\begin{array}{c}0.82 \\
\pm 0.11\end{array}$ & $\begin{array}{c}1.29 \\
\pm 0.31\end{array}$ & $\begin{array}{c}0.92 \\
\pm 0.13\end{array}$ & $\begin{array}{r}1.00 \\
\pm 0.0\end{array}$ & $\begin{array}{r}3.00 \\
\pm 0.0\end{array}$ \\
\hline $\begin{array}{c}\text { Sep. } \\
\pm \text { S.D. }\end{array}$ & $\begin{array}{r}1.10 \\
\pm 0.45 \\
\end{array}$ & 1.70 & $\begin{array}{c}1.01 \\
\pm 0.32\end{array}$ & $\begin{array}{c}1.63 \\
\pm 0.18\end{array}$ & $\begin{array}{c}5.10 \\
\pm 1.88\end{array}$ \\
\hline $\begin{array}{r}\text { Oct. } \\
\pm \text { S.D. }\end{array}$ & & & $\begin{array}{r}1.72 \\
\pm 0.45\end{array}$ & $\begin{array}{c}1.15 \\
\pm 0.14\end{array}$ & \\
\hline $\begin{array}{c}\text { Nov. } \\
\pm \text { S.D. }\end{array}$ & $\begin{array}{c}1.60 \\
\pm 0.20\end{array}$ & & $\begin{array}{r}1.60 \\
\pm 0.38\end{array}$ & $\begin{array}{c}1.59 \\
\pm 0.46\end{array}$ & \\
\hline $\begin{array}{l}\text { Dec. } \\
\pm \text { S.D. }\end{array}$ & & $\begin{array}{c}1.09 \\
\pm 0.19 \\
\end{array}$ & $\begin{array}{c}1.26 \\
\pm 0.40 \\
\end{array}$ & $\begin{array}{c}1.28 \\
+0.28 \\
\end{array}$ & \\
\hline Yearly & 1.20 & 1.27 & 1.14 & 1.28 & 4.95 \\
\hline
\end{tabular}

(- indicates no data were obtained due to lack of sample or organisms in sample.) 
Table 14. Mean monthly size values (mm) $( \pm$ S.D.) of different Cladocera species at Seven Bays (Index Station 6) in 1993.

\begin{tabular}{|c|c|c|c|c|c|}
\hline & $\begin{array}{l}\text { D. galeata } \\
\text { mendotae } \\
(\mathrm{mm})\end{array}$ & $\begin{array}{l}\text { Daphnia } \\
\text { retrocurva } \\
\text { (mm) }\end{array}$ & $\begin{array}{l}\text { Daphnia } \\
\text { schødleri } \\
\text { (mm) }\end{array}$ & $\begin{array}{c}\text { Daphnia } \\
\text { thorata } \\
\text { (mm) }\end{array}$ & $\begin{array}{l}\text { Leptodora } \\
\text { kindti } \\
(\mathrm{mm})\end{array}$ \\
\hline $\begin{array}{l}\text { Jan. } \\
\pm \text { S.D. }\end{array}$ & - & - & 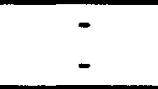 & 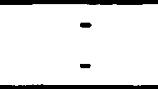 & - \\
\hline $\begin{array}{c}\text { Feb. } \\
\pm \text { S.D. }\end{array}$ & - & I & $\begin{array}{c}1.08 \\
\pm 0.22\end{array}$ & - & - \\
\hline $\begin{array}{l}\text { Mar. } \\
\pm \text { S.D. }\end{array}$ & - & $=$ & $\begin{array}{c}1.36 \\
\pm 0.14 \\
\end{array}$ & $E$ & - \\
\hline $\begin{array}{r}\text { Apr. } \\
\pm \text { S.D. }\end{array}$ & $\begin{array}{l}0.78 \\
0.05\end{array}$ & - & $\begin{array}{c}0.75 \\
\pm 0.13\end{array}$ & - & 5 \\
\hline $\begin{array}{c}\text { May } \\
\pm \text { S.D. }\end{array}$ & $\begin{array}{c}0.88 \\
\pm 0.11\end{array}$ & - & $\begin{array}{c}1.18 \\
\pm 0.35\end{array}$ & - & - \\
\hline $\begin{array}{l}\text { Jun. } \\
\pm \text { S.D. }\end{array}$ & $\begin{array}{c}1.03 \\
\pm 0.17\end{array}$ & $\begin{array}{c}0.82 \\
\pm 0.05\end{array}$ & $\begin{array}{c}1.18 \\
\pm 0.46\end{array}$ & - & $\begin{array}{c}4.89 \\
\pm 2.31\end{array}$ \\
\hline $\begin{array}{c}\text { Jul. } \\
\pm \text { S.D. }\end{array}$ & $\begin{array}{c}1.11 \\
\pm 0.24\end{array}$ & $\begin{array}{c}1.31 \\
\pm 0.42 \\
\end{array}$ & $\begin{array}{c}1.02 \\
\pm 0.37 \\
\end{array}$ & $\begin{array}{c}1.50 \\
\pm 0.10\end{array}$ & - \\
\hline $\begin{array}{r}\text { Aug. } \\
\pm \text { S.D. }\end{array}$ & $\begin{array}{r}1.30 \\
\pm 0.13 \\
\end{array}$ & $=$ & $\begin{array}{r}1.52 \\
\pm 0.50 \\
\end{array}$ & $\begin{array}{c}1.64 \\
\pm 0.53 \\
\end{array}$ & $\begin{array}{c}5.67 \\
\pm 0.71 \\
\end{array}$ \\
\hline $\begin{array}{c}\text { Sep. } \\
\pm \text { S.D. }\end{array}$ & $\begin{array}{c}0.90 \\
\pm 0.10\end{array}$ & - & $\begin{array}{l}1.20 \\
\pm 40 \\
\end{array}$ & $\begin{array}{c}0.90 \\
\pm 0.20\end{array}$ & - \\
\hline $\begin{array}{c}\text { Oct. } \\
\pm \text { S.D. }\end{array}$ & $\begin{array}{c}1.10 \\
\pm 0.20 \\
\end{array}$ & 5 & $\begin{array}{c}1.40 \\
\pm 0.30 \\
\end{array}$ & - & - \\
\hline $\begin{array}{l}\text { Nov. } \\
\pm \text { S.D. }\end{array}$ & & & & & \\
\hline $\begin{array}{c}\text { Dec. } \\
\pm \text { S.D. }\end{array}$ & $\begin{array}{c}1.10 \\
\pm 0.32 \\
\end{array}$ & $\begin{array}{r}1.33 \\
\pm 0.32 \\
\end{array}$ & $\begin{array}{c}1.47 \\
\pm 0.41 \\
\end{array}$ & $\begin{array}{c}1.64 \\
\pm 0.54 \\
\end{array}$ & \\
\hline $\begin{array}{l}\text { Yearly } \\
\text { Mean }\end{array}$ & 1.03 & 1.15 & 1.22 & 1.42 & 5.28 \\
\hline
\end{tabular}

(- indicates no data were obtained due to lack of sample or organisms in sample.) 
Table 15. Mean monthly size values $(\mathrm{mm})( \pm$ S.D.) of different Cladocera species at Spring Canyon (Index Station 9) in 1993.

\begin{tabular}{|c|c|c|c|c|c|}
\hline & $\begin{array}{l}\text { D. galeata } \\
\text { mendotae } \\
(\mathrm{mm})\end{array}$ & $\begin{array}{l}\text { Daphnia } \\
\text { retrocurva } \\
\text { (mm) }\end{array}$ & $\begin{array}{l}\text { Daphnia } \\
\text { schødleri } \\
\text { (mm) }\end{array}$ & $\begin{array}{c}\text { Daphnia } \\
\text { thorata } \\
\text { (mm) }\end{array}$ & $\begin{array}{l}\text { Leptodora } \\
\text { kindti } \\
\text { (mm) }\end{array}$ \\
\hline $\begin{array}{l}\text { Jan. } \\
\pm \text { S.D. }\end{array}$ & - & $\begin{array}{l}- \\
-\end{array}$ & - & $\begin{array}{l}- \\
-\end{array}$ & - \\
\hline $\begin{array}{c}\text { Feb. } \\
\pm \text { S.D. } \\
\end{array}$ & - & - & $\begin{array}{c}0.90 \\
\pm 0.27 \\
\end{array}$ & 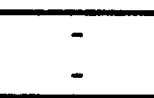 & - \\
\hline $\begin{array}{c}\text { Mar. } \\
\pm \text { S.D. } \\
\end{array}$ & - & - & $\begin{array}{c}0.77 \\
\pm 0.06\end{array}$ & - & - \\
\hline $\begin{array}{c}\text { Apr. } \\
\pm \text { S.D. }\end{array}$ & - & - & $\begin{array}{c}1.15 \\
\pm 0.25\end{array}$ & - & 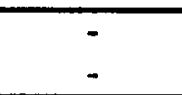 \\
\hline $\begin{array}{c}\text { May } \\
\pm \text { S.D. }\end{array}$ & - & - & $\begin{array}{c}1.24 \\
\pm 0.21\end{array}$ & - & - \\
\hline $\begin{array}{c}\text { Jun. } \\
\pm \text { S.D. }\end{array}$ & - & - & $\begin{array}{c}1.62 \\
\pm 0.38\end{array}$ & $\begin{array}{c}1.24 \\
-\end{array}$ & $\begin{array}{r}9.50 \\
\pm 3.66\end{array}$ \\
\hline $\begin{array}{r}\text { Jul. } \\
\pm \text { S.D. }\end{array}$ & $\begin{array}{c}1.12 \\
-\end{array}$ & $\begin{array}{c}1.14 \\
\pm 0.23\end{array}$ & $\begin{array}{c}1.11 \\
\pm 0.33\end{array}$ & - & - \\
\hline $\begin{array}{c}\text { Aug. } \\
\pm \text { S.D. } \\
\end{array}$ & $\begin{array}{r}1.02 \\
\pm 0.14 \\
\end{array}$ & - & $\begin{array}{r}1.24 \\
\pm 0.38 \\
\end{array}$ & $\begin{array}{c}1.48 \\
\pm 0.38\end{array}$ & $\overline{-}$ \\
\hline $\begin{array}{r}\text { Sep. } \\
\pm \text { S.D. } \\
\end{array}$ & $\begin{array}{c}1.24 \\
\pm 0.46 \\
\end{array}$ & - & $\begin{array}{c}1.40 \\
\pm 0.38\end{array}$ & $\begin{array}{c}1.20 \\
-\end{array}$ & - \\
\hline $\begin{array}{c}\text { Oct. } \\
\pm \text { S.D. } \\
\end{array}$ & $\begin{array}{c}1.63 \\
\pm 0.29 \\
\end{array}$ & $\begin{array}{r}1.09 \\
\pm 0.13 \\
\end{array}$ & $\begin{array}{c}0.89 \\
\pm 0.20 \\
\end{array}$ & $\begin{array}{c}2.24 \\
- \\
\end{array}$ & - \\
\hline $\begin{array}{l}\text { Nov. } \\
\pm \text { S.D. } \\
\end{array}$ & - & $\begin{aligned} 1.45 \\
\pm 0.30 \\
\end{aligned}$ & $\begin{array}{r}1.40 \\
\pm 0.37 \\
\end{array}$ & - & - \\
\hline $\begin{array}{r}\text { Dec. } \\
\pm \text { S.D. } \\
\end{array}$ & - & $\begin{array}{l}- \\
- \\
\end{array}$ & $\begin{array}{r}1.37 \\
\pm 0.37 \\
\end{array}$ & - & - \\
\hline $\begin{array}{c}\text { Yearly } \\
\text { Mean } \\
\end{array}$ & 1.25 & 1.23 & 1.19 & 1.54 & 9.50 \\
\hline
\end{tabular}

(- indicates no data were obtained due to lack of sample or organisms in sample.) 
mm, and; Leptodora kindti - $8.00 \mathrm{~mm}$. Yearly mean lengths of cladocera at Porcupine Bay are: Daphnia galeata mendotae - $1.20 \mathrm{~mm}$; Daphnia retrocurva - $1.27 \mathrm{~mm}$; Daphnia schødleri - 1.14 mm; Daphnia thorata - $1.28 \mathrm{~mm}$, and; Leptodora kindti - $4.95 \mathrm{~mm}$. Yearly mean lengths of cladocera at Seven Bays are: Daphnia galeata mendotae - 1.03 mm; Daphnia retrocurva - 1.15 mm; Daphnia schфdleri - 1.22 mm; Daphnia thorata - 1.42 $m m$, anE, Leptodora kindti - 5.28. mm. Yearly mean lengths of cladocera at Spring Canyon are: Daphnia galeata mendotae - $1.25 \mathrm{~mm}$; Daphnii retrocurva - $1.23 \mathrm{~mm}$; Daphnia schødleri - $1.19 \mathrm{~mm}$; Daphnia thorata - $1.54 \mathrm{~mm}$, and; Leptodora kindti - 9.50. $\mathrm{mm}$. 


\section{MACROINVERTEBRATES}

\section{Methods}

Quantitative samples of benthic macroinvertebrates were collected using a Ponar dredge with a $0.053 \mathrm{~m}$ opening. Benthos were collected from March through September at Gifford, Porcupine Bay, Seven Bays, and Spring Canyon. Three replicate samples were taken from each of the following reservoir elevations at each station: area 1 - below elevation 1,210 ft; area $2-1,240$ to $1,211 \mathrm{ft}$; and area $3-1,290 \mathrm{ft}$ (full pool) to 1,241 ft.

Benthic samples were sub-sampled. Grab mixtures were stirred, allowed to settle, and top water poured off through a series of U.S. Standard sieves that measured $4 \mathrm{~mm}, 2$ $\mathrm{mm}$, and $0.5 \mathrm{~mm}$. Material that remained on the final screen was retained and preserved in $10 \%$ formalin solution, labeled "top water" and later transferred to $70 \%$ alcohol. The remaining grab was weighed. If weight of the remaining sample was less than $1 \mathrm{~kg}$ the entire sample was filtered through the sieves and preserved. If the sample was greater than $1 \mathrm{~kg}$ three sub-samples of $10 \%$ by weight were taken. Each sub-sample was filtered through the series of sieves, labeled accordingly and preserved in the same manner.

Organisms were sorted and identified to family using the taxonomic keys of Brooks (1957), Ward and Whipple (1966), Borror et al. (1976), Ruttner-Kolisko (1974), Edmonds et al. (1976), Wiggins (1977), Pennak (1978;1989), and Merritt and Cummins (1984).

The average weight of a single organism for each species was determined on a yearly basis to obtain wet weight values. Yearly figures were used instead of monthly due to the lack of variance in data between 1992 and 1993. Excess moisture was removed from each organism and the organism was weighed to the nearest $0.0001 \mathrm{~g}$ using a Sartorius Model H51 analytical balance (Weber 1973, APHA 1976). Monthly values were used in weight calculations.

Number and weight values obtained were converted to densities and expressed in number/m2 and grams/m2. Number and weight density values were averaged for each season to obtain seasonal means and seasonal percent occurrence. Mean seasonal data were averaged to obtain unbiased annual means.

Emerging benthic macroinvertebrates were sampled with a square meter emergence 
trap constructed of $1 / 4$ inch thick fiberglass (Figure 8). Styrofoam strips were attached to the bottom of the trap for flotation and the trap was anchored to a five gallon bucket filled with concrete. Holes were cut in each side of the trap and the top of the catch basin to reduce condensation problems and allow for evaporation on the inside of the trap. Holes were covered with cloth. This trap is a modification of emergence traps used by May $\boldsymbol{e t .} \boldsymbol{\alpha}$ (1988) on Hungry Horse Reservoir. Traps were set from June to October at Gifford, Porcupine Bay, Seven Bays, and Spring Canyon. At each location, one trap was placed in near shore areas at water depths less than $15 \mathrm{~m}$ at full pool. These areas were dewatered annually during the study. A second trap was placed at each location in offshore areas at water depths greater than 15 to $26 \mathrm{~m}$ below full pool. A third trap was placed in offshore areas at water depths greater than $26 \mathrm{~m}$ below full pool. Traps were filled with anti-freeze to preserve insects and checked twice each month. All insects were sorted, identified to order and counted.

Number values obtained were converted to density and expressed as number $/ \mathrm{m}^{2}$. Number density values were averaged for each season to obtain seasonal means and seasonal percent occurrence. Mean seasonal data were averaged to obtain unbiased annual means.

Resuits and Discussion

\section{Ben thos}

A total of 10 benthic macroinvertebrate families from 7 orders were found in the substrate samples from Lake Roosevelt. Tables 16 through 19 show the mean benthic macroinvertebrate number and weight densities from Gifford, Porcupine Bay, Seven Bays, and Spring Canyon from March to October 1993.

At depths of $26 \mathrm{~m}$ or greater at full pool (area 1), mean benthic macroinvertebrate densities and weights at Gifford were consistently composed of midges and worms in all sampling. In areas $2(15-26 \mathrm{~m}$ ) and area 3 (less that $15 \mathrm{~m}$ ) caddis flies and other were observed while midges and worms represented the majority. At Porcupine Bay, areas 1, 2, and 3 were primarily comprised of midges and worms. As at Gifford, the closer to shore, more diverse organisms were found. Seven Bays and Spring Canyon both have highest densities of worms and midges in the deeper waters, while more caddis flies and scuds were collected in the deeper areas at Seven Bays as compared to Spring Canyon where scuds were more prevalent than caddisflies or other. Snails were only found in the deepest areas of Spring Canyon and Porcupine Bay. 


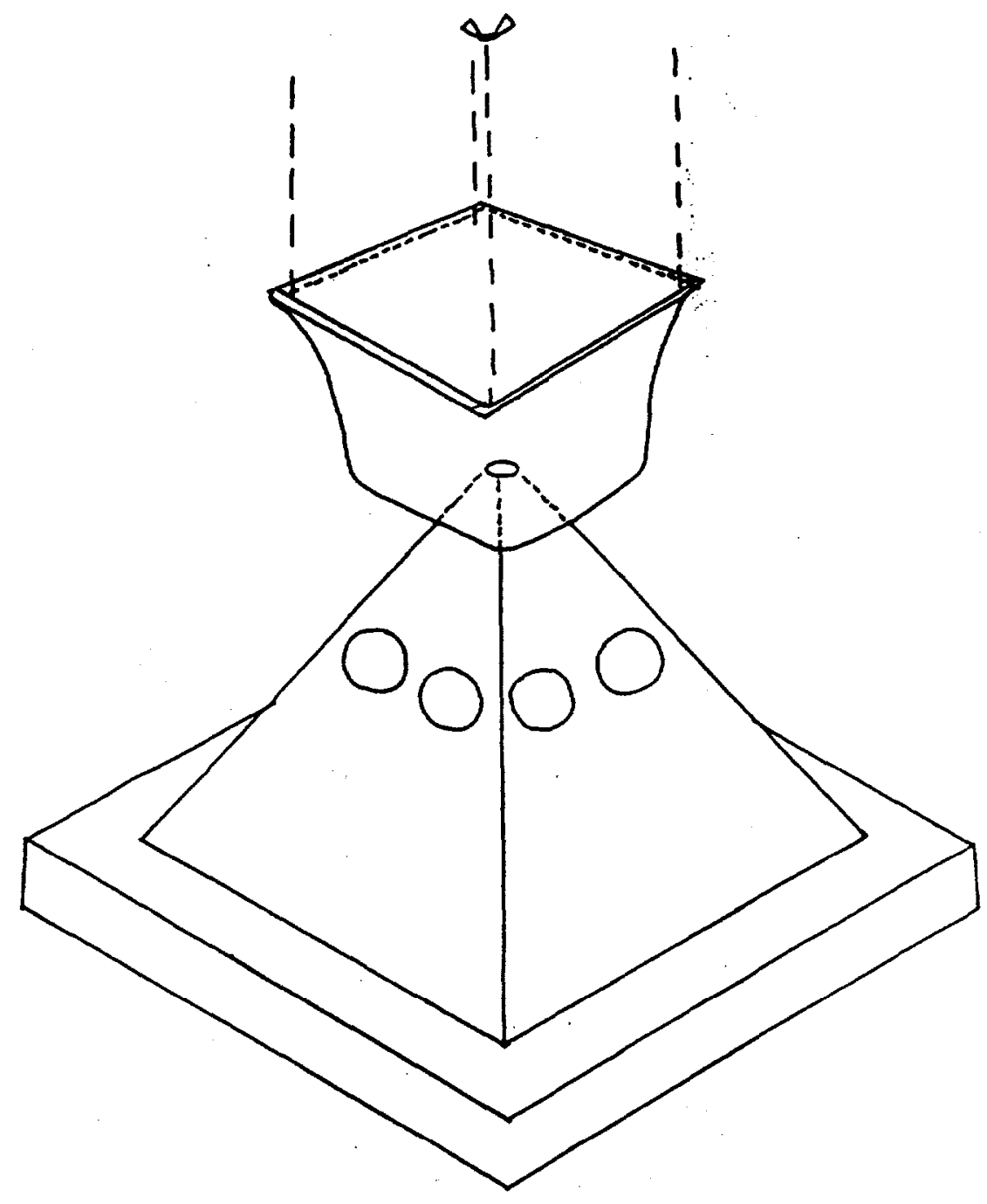

Figure 8. Benthic macroinvertebrate emergence trap used on Lake Roosevelt. 
Table 16. $\quad$ Mean number $\left(\# / \mathbf{m}^{\mathbf{2}}\right)$ and weight $\left(\mathbf{g} / \mathbf{m}^{\mathbf{2}}\right)$ density values for groups of benthic organisms at Gifford sampling locations on Lake Roosevelt,- WA in 1993.

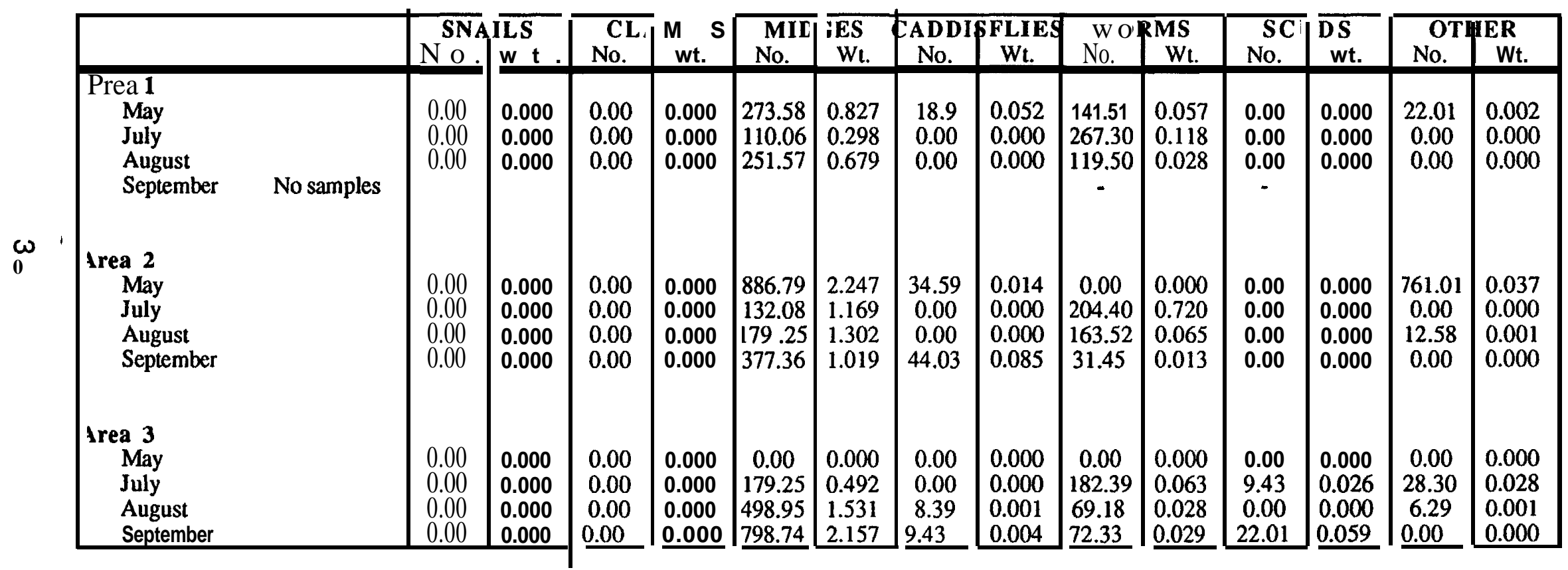


Table 17. $\quad$ Mean number $\left(\# / \mathbf{m}^{\mathbf{2}}\right)$ and weight $\left(\mathbf{g} / \mathbf{m}^{\mathbf{2}}\right)$ density values for groups of benthic organisms at Porcupine Bay sampling locations on Lake Roosevelt, WA in 1993.

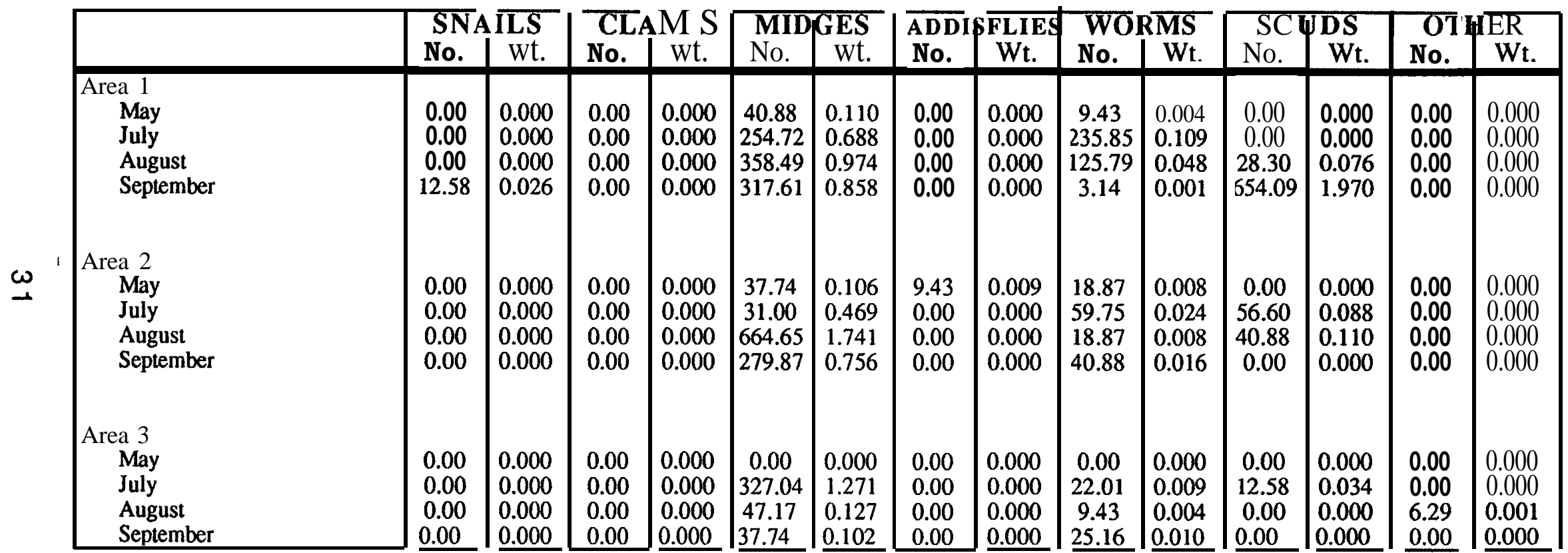


Table 18. Mean number $\left(\# / \mathbf{m}^{\mathbf{2}}\right)$ and weight $\left(\mathbf{g} / \mathbf{m}^{\mathbf{2}}\right)$ density values for groups of benthic organisms at Seven Bays sampling locations on Lake Roosevelt, WA in 1993.

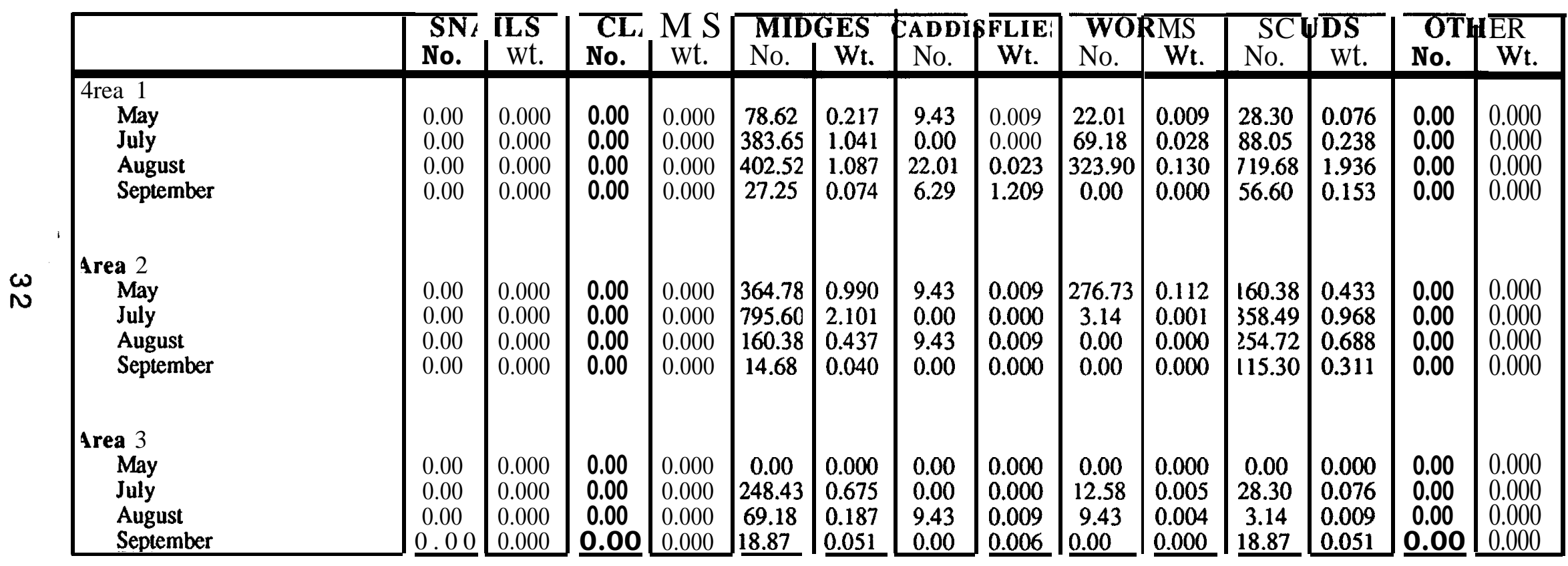


Table 19. Mean number $\left(\# / \mathbf{m}^{\mathbf{2}}\right)$ and weight $\left(\mathbf{g} / \mathbf{m}^{\mathbf{2}}\right)$ density values for groups of benthic organisms at Spring Canyon sampling locations on Lake Roosevelt, WA in 1993.

\begin{tabular}{|c|c|c|c|c|c|c|c|c|c|c|c|c|c|c|}
\hline & SN & ILS & $\overline{C L}$ & $\sqrt{\mathrm{MS}}$ & $\overline{\text { MID }}$ & $\overline{\text { GES }}$ & $\overline{\text { CADDI }}$ & FLIE: & Wol & $\mathrm{MS}$ & $\mathrm{SC}^{\prime}$ & $\overline{\mathrm{DS}}$ & $\overline{\mathrm{OT}}$ & IER \\
\hline & No. & Wt. & No. & wt. & No. & wt. & No. & Wt. & No. & Wt. & No. & wt. & No. & Wt. \\
\hline $\begin{array}{l}\text { May } \\
\text { July }\end{array}$ & $\begin{array}{l}9.43 \\
0.00\end{array}$ & $\begin{array}{l}0.020 \\
0.000\end{array}$ & $\begin{array}{l}0.00 \\
0.00\end{array}$ & $\begin{array}{l}0.000 \\
0.000\end{array}$ & $\begin{array}{l}286.16 \\
10063\end{array}$ & $\begin{array}{l}0.773 \\
0273\end{array}$ & $\begin{array}{l}0.00 \\
0.00\end{array}$ & $\begin{array}{l}0.000 \\
0.000\end{array}$ & $\begin{array}{l}194.97 \\
44.03\end{array}$ & $\begin{array}{l}0.078 \\
0.018\end{array}$ & $\begin{array}{c}150.94 \\
000\end{array}$ & 0.408 & 0.00 & 0.000 \\
\hline September & 0.00 & 0.000 & 0.00 & 0.000 & 270.44 & 0.730 & 8.39 & 0.008 & 23.06 & 0.002 & 0.00 & 0.000 & 0.00 & 0.000 \\
\hline trea 2 & & & & & & & & & & & & & & \\
\hline August & 0.00 & 0.000 & 0.00 & 0.000 & 106.92 & 0.291 & 0.00 & 0.000 & 117.40 & 0.047 & 20.96 & 0.057 & 2.10 & $<0.001$ \\
\hline September & 0.00 & 0.000 & 0.00 & 0.000 & 0.00 & 0.000 & 0.00 & 0.000 & 26.03 & 0.002 & 6.29 & 0.017 & 0.00 & 0.000 \\
\hline trea 3 & & & & & & & & & & & & & & \\
\hline May & 0.00 & 0.000 & 0.00 & 0.000 & 0.00 & 0.000 & 0.00 & 0.000 & 0.00 & 0.000 & 0.00 & 0.000 & 0.00 & 0.000 \\
\hline July & 0.00 & 0.000 & 0.00 & 0.000 & 48.22 & 0.335 & 0.00 & 0.000 & 40.88 & 0.016 & 50.31 & 0.013 & 0.00 & 0.000 \\
\hline
\end{tabular}




\section{Emergence}

A total of 2 benthic macroinvertebrate orders were found in emergence traps located at Gifford, Porcupine Bay, Seven Bays, and Spring Canyon in June and July. Table 20 shows the number and annual mean of benthic macroinvertebrates collected in emergence traps.

Twelve emergence traps were set in June throughout the reservoir at sites designated. However six traps were substantially damaged and pulled from the reservoir or lost within the reservoir by the end of July. On several occasions traps were damaged or vandalized, and all antifreeze and any emerged benthics were lost. June and July were the only months that any emergence were found in these traps and vandalism did not occur. Seven Bays is the only site which all three traps were functioning in June and July. Diptera were collected in all three areas in both months, and had an emergence number of $69 / \mathrm{m}^{2}$. At ail other locations, diptera were observed. Order Odonata was collected from area 2 (depths between 15 and $26 \mathrm{~m}$ ) at Seven Bays. Only one organism was collected out of the six traps. Warmer temperature in the shallow zones relative to the deeper zones may account for the high rates of emergence there. Oliver (197 1) stated that larvae mature faster in warmer water. As in Libby Reservoir, the potential for a continued supply of dipterans throughout the warmer months is high. However due to water level fluctuations, the full potential of the shallow zone will never be realized because of the reduction in wetted substrate (Chisholm, et al. 1983-87). 
Table 20. Mean number $\left(\# / \mathbf{m}^{\mathbf{2}}\right)$ density values for groups of benthic organisms captured in emergence traps located at Gifford, Porcupine Bay, Seven Bays, and Spring Canyon, Lake Roosevelt, WA in 1993.

\begin{tabular}{|c|c|c|}
\hline & June & July \\
\hline \multicolumn{3}{|l|}{ Location Gifford } \\
\hline Diptera (midges) & & 0 \\
\hline Odonata (dragonflies) & 0 & 0 \\
\hline Annual mean for all benthics \pm s.d. & $17 \mathrm{f} 0$ & - \\
\hline \multicolumn{3}{|l|}{ Location Porcupine Bay } \\
\hline Diptera (midges) & 0 & \\
\hline Odonata (dragonflies) & 0 & 0 \\
\hline Annual mean for all benthics \pm s.d. & & $4.0 \pm 0$ \\
\hline \multicolumn{3}{|l|}{$\begin{array}{l}\text { Location Seven Bays } \\
\text { Area } 1\end{array}$} \\
\hline Diptera (midges) & 22 & 9 \\
\hline Odonata (dragonflies) & 0 & 0 \\
\hline \multicolumn{3}{|l|}{$\begin{array}{l}\text { Location Seven Bays } \\
\text { Area } 2\end{array}$} \\
\hline $\begin{array}{l}\text { Diptera (midges) } \\
\text { Odonata (dragonflies) }\end{array}$ & $\begin{array}{c}116 \\
1\end{array}$ & $\begin{array}{c}18 \\
0\end{array}$ \\
\hline \multicolumn{3}{|l|}{$\begin{array}{l}\text { Location Seven Bays } \\
\text { Area } 3\end{array}$} \\
\hline $\begin{array}{l}\text { Diptera (midges) } \\
\text { Odonata (dragonflies) }\end{array}$ & $\begin{array}{l}0 \\
0\end{array}$ & $\begin{array}{c}28 \\
0\end{array}$ \\
\hline Annual mean for all benthics \pm s.d. & $46.3 \pm 61.2$ & $18.3 \pm 9.5$ \\
\hline \multicolumn{3}{|l|}{$\begin{array}{l}\text { Location Spring Canyon } \\
\text { Area } 1\end{array}$} \\
\hline Diptera (midges) & 31 & 0 \\
\hline Odonata (dragonflies) & 0 & 0 \\
\hline Annual mean for all benthics \pm s.d. & $31.0 \pm 0$ & \\
\hline
\end{tabular}




\section{EXPERIMENTAL TRAWLING}

\section{Methods}

The Idaho Department of Fish and Game in conjunction with the Spokane Tribe of Indians trawled Lake Roosevelt in August to determine if trawling was a suitable methodology to estimate kokanee (Oncorhynchus nerka) densities in the reservoir (Maiolie and Elam, 1993). Oblique tows of a Hauser types mid-water trawl were used to obtain density estimates and representative samples of fish. An $8.5 \mathrm{~m}, 140$ horsepower diesel engine boat towed a $13.7 \mathrm{~m}$ long trawl net with a $3 \mathrm{~m}$ by $3 \mathrm{~m}$ mouth. Mesh sizes (stretch measure) graduated from $32 \mathrm{~mm}$ to $25 \mathrm{~mm}$ to $19 \mathrm{~mm}$ to $13 \mathrm{~mm}$ in the body of the net and terminated in a $6 \mathrm{~mm}$ mesh cod end. Rieman (1992) presented a detailed description of the methodology.

Trawling was conducted after dark during the new moon phase to optimize capture efficiency (Bowler et al. 1979). Net towing speed was standardized at $1.5 \mathrm{~m} / \mathrm{s}$. Depth of the net was determined for each $15.2 \mathrm{~m}$ distance of tow cable and checked annually. Kokanee distribution is determined using a Raytheon Model V860 depth sounder with a 20 degree transducer. Step-wise oblique net tows were made from depths of $34.4 \mathrm{~m}$ to a minimum depth of $3.4 \mathrm{~m}$. The trawl net was pulled for 3 minutes in each "step", sampling $2,832 \mathrm{~m}^{3}$ of water over a distance of $315 \mathrm{~m}$, at boat speed of $1.5 \mathrm{~m} / \mathrm{s}$. The net was then raised $3 \mathrm{~m}$ and sampling continued for another $3 \mathrm{~min}$. The time it took to readjust the net between steps and the time the net was sampling while initially setting the net was also entered into density estimates (approximately 30 seconds between sublayers while raising and lowering the net).

Eight trawls from the buoys in front of Grand Coulee Dam upstream for a distance of $18 \mathrm{~km}$ to river mile 608 were completed. Two more trawls were conducted in the Spokane Arm about $5 \mathrm{~km}$ and $8 \mathrm{~km}$ from the mouth. The last trawl was conducted in the main reservoir beginning at a point just north of the mouth of the Spokane Arm and continued in a southerly direction for $3 \mathrm{~km}$.

Results and Discussion

No kokanee were collected in the eleven trawls performed by Idaho Department of Fish and Game. In the main reservoir, few fish were seen on the echosounder in the 
pelagic zone. No layer of kokanee could be seen even with extensive echosounding. In the Spokane Arm a layer of fish was seen on the echosounder near the bottom in $27 \mathrm{~m}$ to $35 \mathrm{~m}$ of water inside the old river channel. Subsequent trawls in this area collected three whitefish up to $596 \mathrm{~mm}$ in length. Density estimate of whitefish in the Spokane Arm was 15 whitefish/ha.

Nearly every trawl collected numerous small sculpins (genus Cottus) from $17 \mathrm{~mm}$ to $37 \mathrm{~mm}$ Densities of sculpins in trawl samples were 66 sculpins/ha in the lower end of the reservoir 56 sculpins/ha in the Spokane Arm, and 101 sculpins/ha in the Seven Bays area (Figure 9) (Maiolie and Elam 1993). The experimental trawling conducted by Idaho Department of Fish and Game, indicated that midwater trawling for kokanee as a sampling devise, was not effective during August in Lake Roosevelt. Few fish were seen on the echosounder and no kokanee were caught in eleven trawls. We believe the kokanee population is too small for collection by this manner. It is possible however, that trawling may be effective at other locations, or other times of the year.

This finding presents an additional question as to why kokanee densities would be so low. Kokanee have been stocked into Lake Roosevelt since 1986 and the Spokane Tribe maintains and operates two kokanee hatcheries on the reservoir. Yet, not even small kokanee were collected. Temperature profiles collected during August documented water temperatures greater than 16 degrees $\mathrm{C}$ above $33 \mathrm{~m}$ (the maximum depth sampled). Kokanee are thought to seek 11 degree $\mathrm{C}$ water at night to aid in food digestion. Possibly kokanee were in areas of cooler water, although it is unknown where that may be. No kokanee layer was seen on the echosounder even at depths to $100 \mathrm{~m}$. If kokanee densities are as low as anticipated, it may indicate very high entrainment losses through Grand Coulee Dam. Entrainment losses may be exacerbated by the somewhat warm temperatures of the reservoir.

Density of kokanee in Lake Roosevelt appear to be too low for their collection by mid-water trawling. Possibly kokanee were missed because they were too deep, of they were in other areas of the reservoir. Trawling at different times of the year may be a suitable way to estimate kokanee densities in the reservoir. It is however likely that their densities are very low and we question whether warm water temperatures, the lack of stratification, predation, natural mortality, and the low water retention time, could result in high entrainment losses and a low population (Maiolie and Elam 1993). 

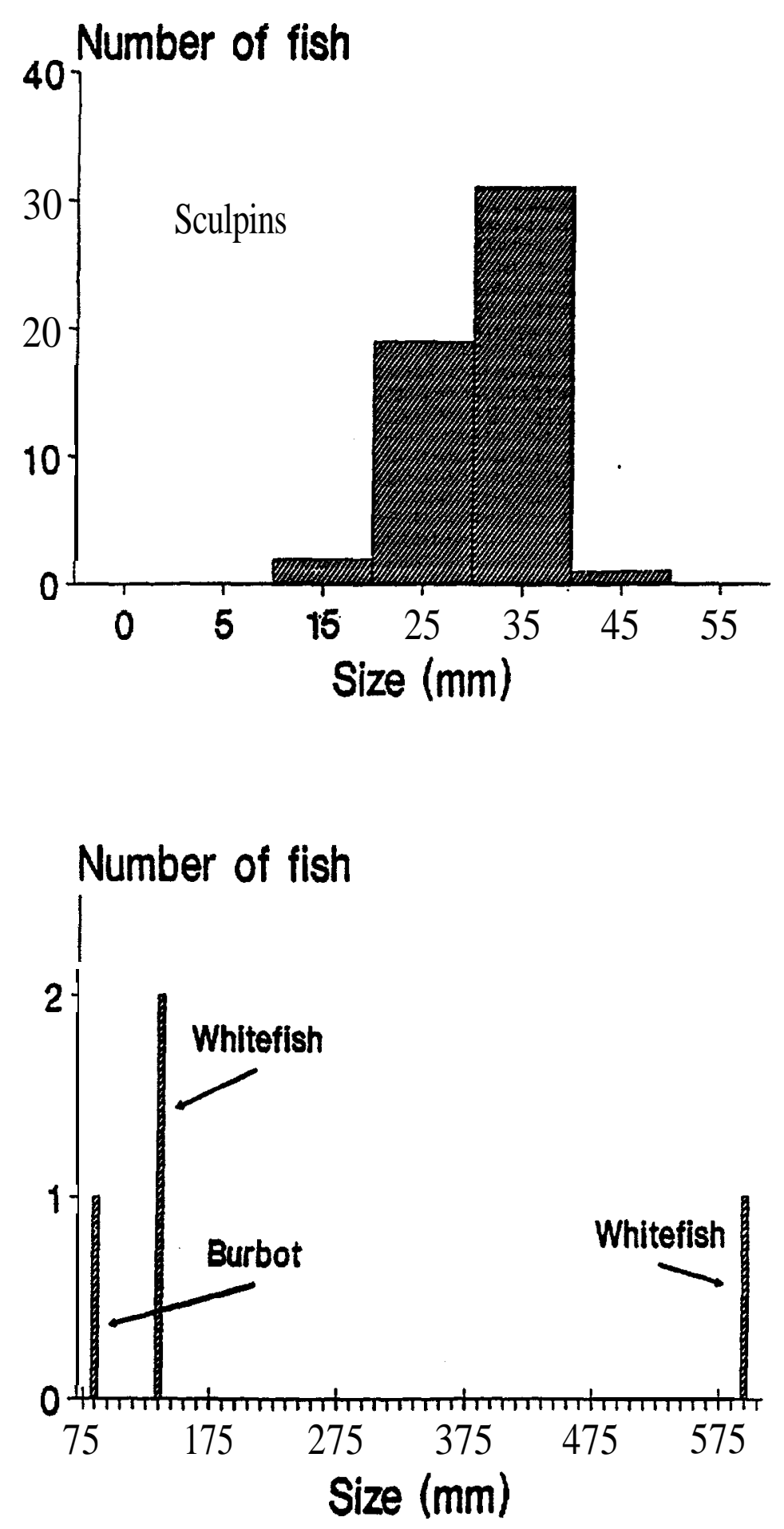

Figure 9. Lengths of sculpins, burbot, and lake whitefish caught trawling in Lake Roosevelt, August 1993. 


\section{TAGGING STUDIES}

Met hods

Tagging studies were conducted with net-pen rainbow trout. Individually numbered Floy tags were inserted into the musculature at the posterior base of the dorsal fin of one year old fish. Rainbow trout were marked, measured, and released at Kettle Falls, Gifford, Hunters, Seven Bays, and Keller Ferry net-pens in 1993. Two thousand fish were tagged and released bi-monthly from each net-pen site in March, April, and May. In June, approximately 300 additional fish were tagged and released from Seven Bays.

Posters were distributed at locations frequented by anglers in the area surrounding Lake Roosevelt. Posters contained information about the Lake Roosevelt Monitoring Program and requested that anglers return tags with recapture date and location, and length and weight of fish. Any angler that returned tag information was sent a letter informing him or her of the release date, location, and length of fish at time of release. The angler was also provided with a brief summary of the tagging program.

Tag return data was compiled and analyzed to determine movement within and through Lake Roosevelt. Movement was analyzed by noting recapture location and plotting it against release location and date.

\section{Results and Discussion}

Tables 21 through 26 summarize fish tag recoveries from each net-pen tagging effort on Lake Roosevelt from 1988 through 1993. In 1993 a total of 21,255 fish were tagged at Hall Creek, Hunters, Seven Bays, and Keller Ferry net-pens in March, April, and May. In 1993, 352 tags were returned from anglers fishing in Lake Roosevelt or below. Of these returns, 106 tags were from fish tagged in 1993. $29 \%$ of these fish were tagged at Hunters, $51 \%$ were tagged at Seven Bays, and $20 \%$ were tagged at Keller Ferry. No tags were recovered from Hall Creek. Three tags were recovered below Lake Roosevelt at Rock Island Dam, from the 1993 tag returns.

Trends in tag returns continue to indicate that entrainment of Lake Roosevelt netpen fish are influenced by water retention times and release times. Percent of fish 
Table 21. Summary of release dates, numbers, and subsequent capture locations of net-pen rainbow trout tagged and released from Kettle Falls.

\begin{tabular}{|c|c|c|c|c|c|c|c|c|}
\hline \multirow[b]{2}{*}{$\begin{array}{c}\text { Release } \\
\text { Date }\end{array}$} & \multirow[b]{2}{*}{$\begin{array}{c}\text { Total } \\
\text { \# Tagged } \\
\end{array}$} & \multirow[b]{2}{*}{$\begin{array}{c}\text { Total \# } \\
\text { Recovered } \\
\end{array}$} & \multirow[b]{2}{*}{$\begin{array}{c}\text { Percent } \\
\text { Recovered } \\
\end{array}$} & \multirow[b]{2}{*}{$\begin{array}{l}\text { Number } \\
\text { Recovered } \\
\text { in FDR }\end{array}$} & \multirow[b]{2}{*}{$\begin{array}{l}\text { Percent } \\
\text { Recovered } \\
\text { in FDR }\end{array}$} & \multicolumn{3}{|c|}{$\begin{array}{c}\text { Recoveries } \\
\text { BE }) \text { W Grand Coulee }\end{array}$} \\
\hline & & & & & & $\begin{array}{l}\text { Number } \\
\text { Recovered } \\
\text { in Rufus } \\
\text { Woods }\end{array}$ & $\begin{array}{c}\text { Number } \\
\text { Recovered } \\
\text { at Rock Is. } \\
\text { or McNary }\end{array}$ & $\begin{array}{c}\text { Percent } \\
\text { Recovered } \\
\text { Below } \\
\text { FDR }\end{array}$ \\
\hline Sep. 89 & 584 & 15 & $3 \%$ & 14 & $93 \%$ & 1 & 0 & $7 \%$ \\
\hline Mar. 90 & 508 & 2 & $\mathrm{c} 1 \%$ & 2 & $100 \%$ & 0 & 0 & $0 \%$ \\
\hline Apr. 90 & 498 & 23 & $5 \%$ & 17 & $74 \%$ & 5 & 1 & $26 \%$ \\
\hline Apr. 91 & 1,000 & 57 & $6 \%$ & 44 & $77 \%$ & 11 & 2 & $21 \%$ \\
\hline Mar. 92 & 1,000 & 13 & $1 \%$ & 13 & $100 \%$ & 0 & 0 & $0 \%$ \\
\hline Apr. 92 & 1,000 & 42 & $4 \%$ & 42 & $98 \%$ & 1 & 0 & $2 \%$ \\
\hline May 92 & 1,000 & 41 & $4 \%$ & 41 & $100 \%$ & 0 & 0 & $0 \%$ \\
\hline
\end{tabular}

No fish were tagged in 1993 at the Kettle Falls net-pens. 
Table 22. Summary of release dates, numbers, and subsequent capture locations of net-pen rainbow trout tagged and released from Gifford.

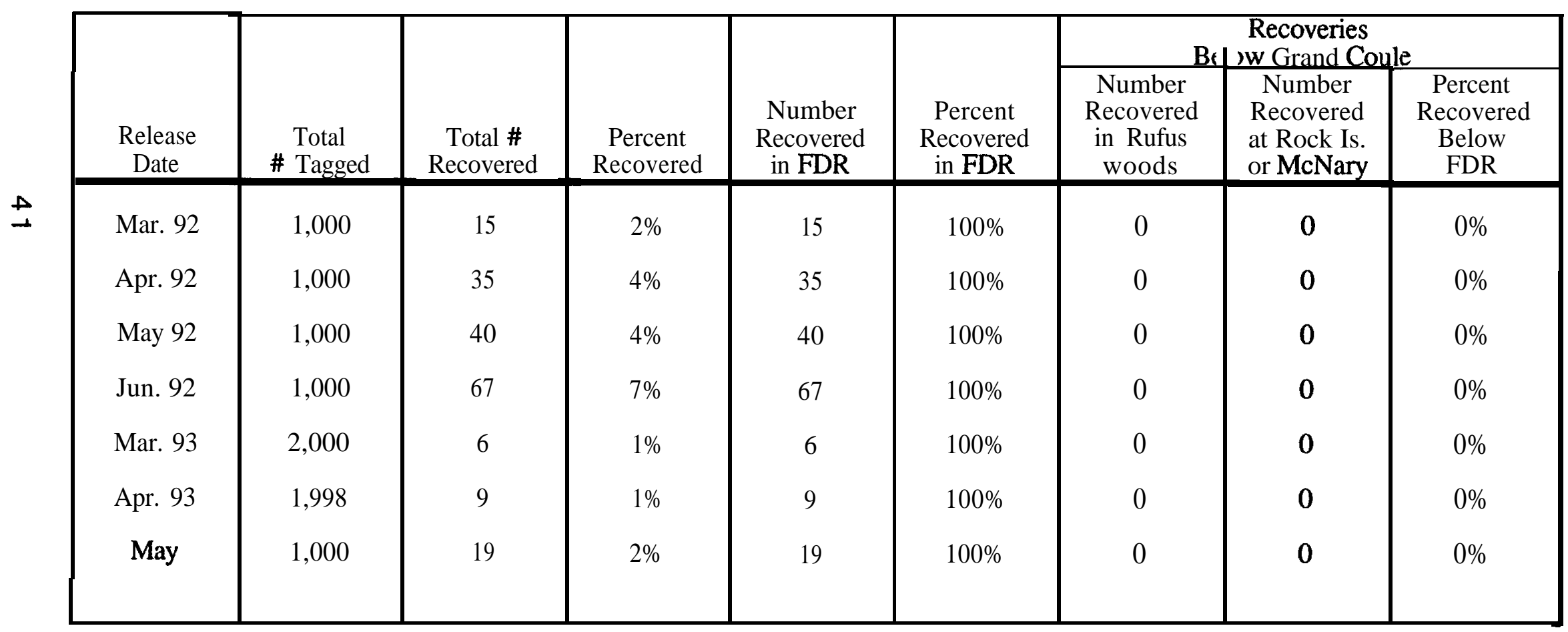


Table 23. ' Summary of release dates, numbers, and subsequent capture locations of net-pen rainbow trout tagged and released from Hunters.

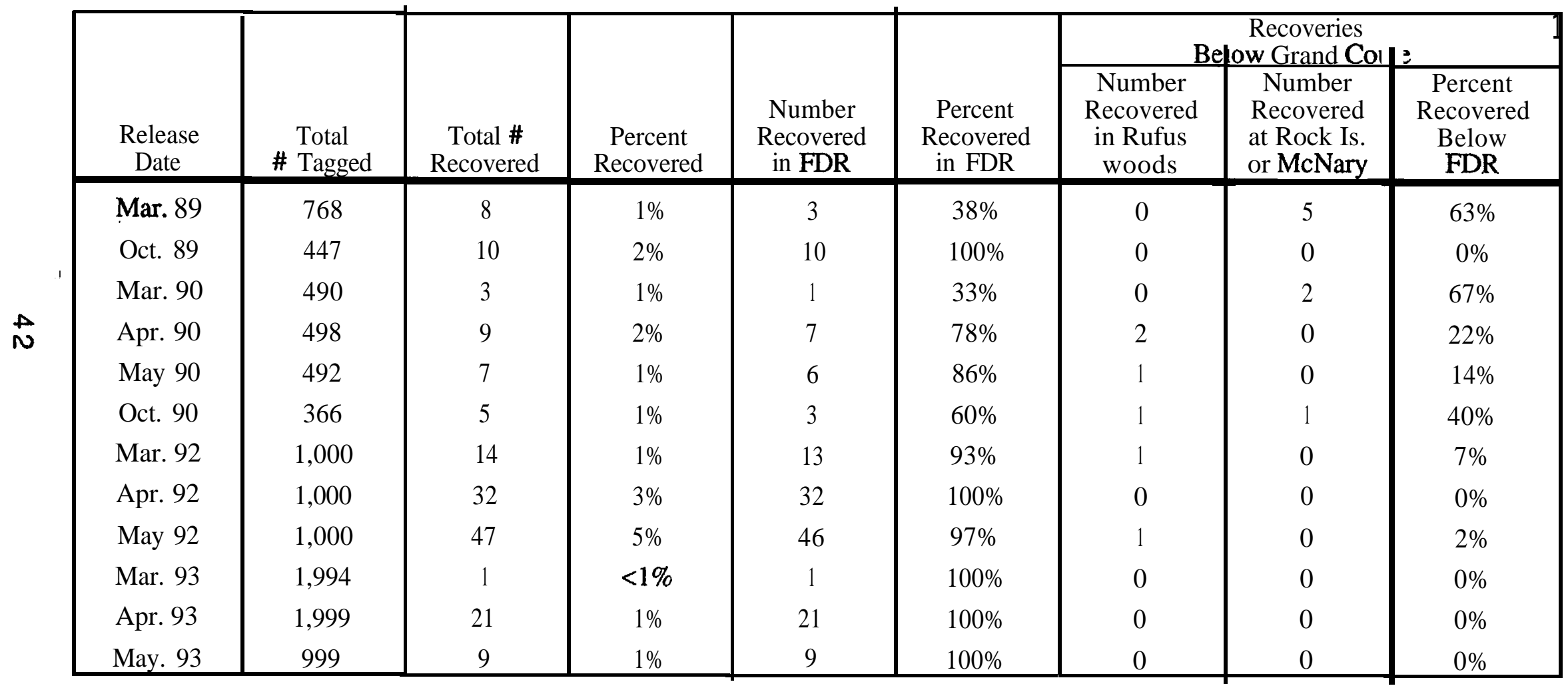




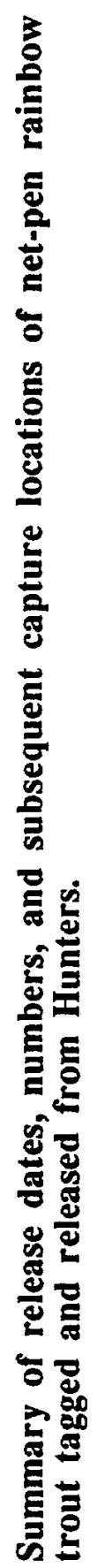

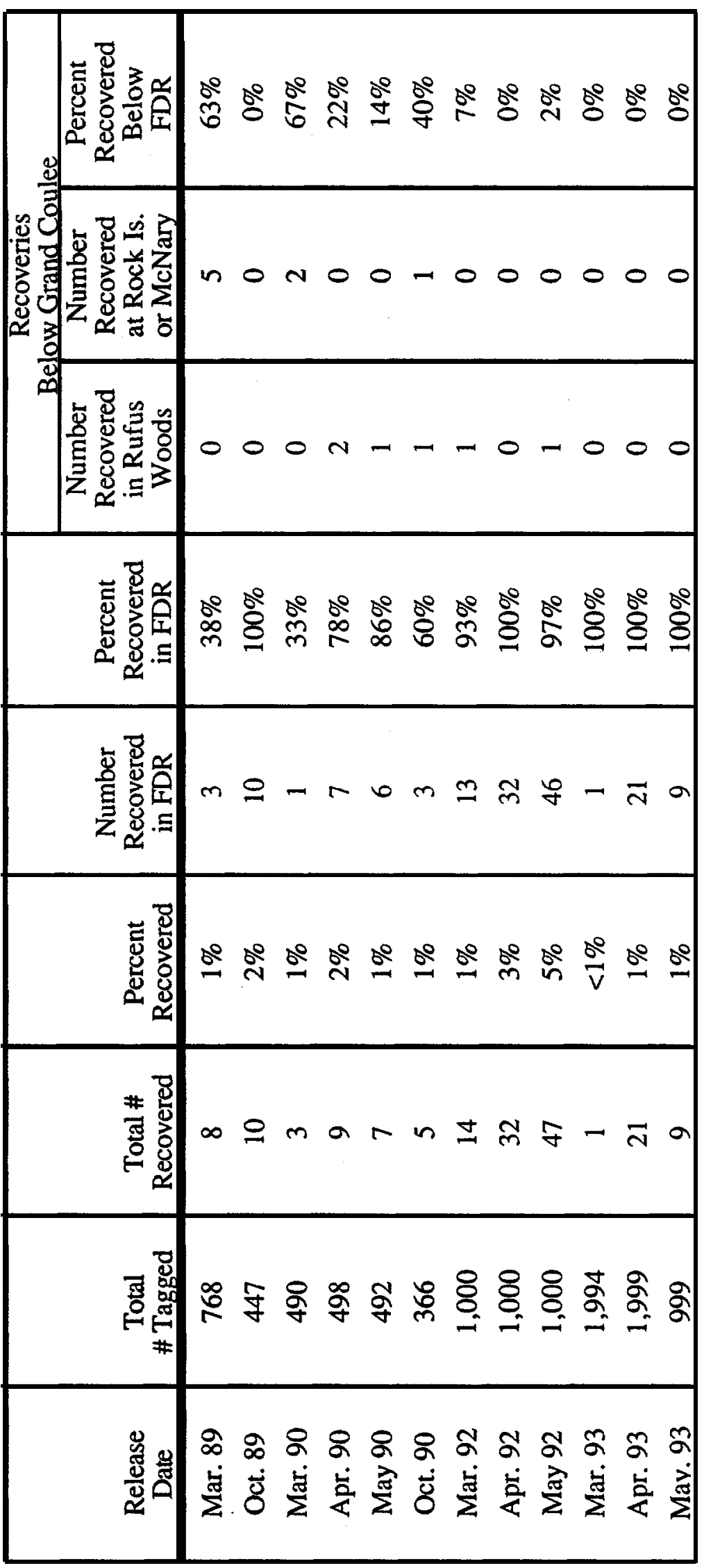


Table 25. Summary of release dates, numbers, and subsequent capture locations of net-pen rainbow trout tagged and released from Lincoln.

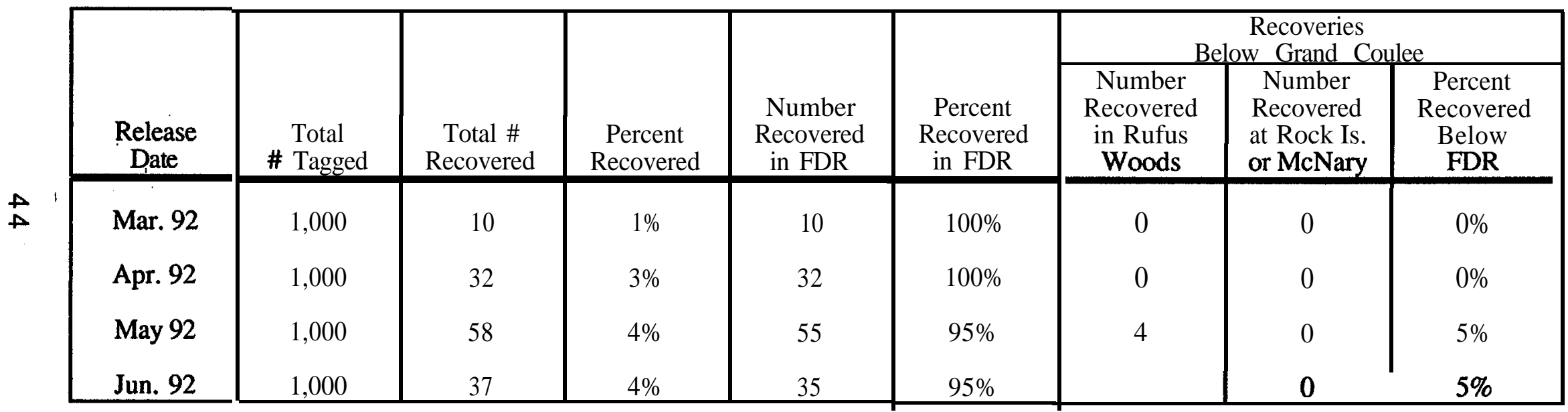

Net-pens were not in operations in 1993 at Linclon. 
Table 26. Summary of release dates, numbers, and subsequent capture locations of net-pen rainbow trout tagged and released from Keller Ferry.

\begin{tabular}{|c|c|c|c|c|c|c|c|c|}
\hline \multirow[b]{2}{*}{$\begin{array}{l}\text { Release } \\
\text { Date }\end{array}$} & \multirow[b]{2}{*}{$\begin{array}{l}\text { Total } \\
\text { \# Tagged }\end{array}$} & \multirow[b]{2}{*}{$\begin{array}{c}\text { Total \# } \\
\text { Recovered }\end{array}$} & \multirow[b]{2}{*}{$\begin{array}{c}\text { Percent } \\
\text { Recovered }\end{array}$} & \multirow[b]{2}{*}{$\begin{array}{l}\text { Number } \\
\text { Recovered } \\
\text { in FDR }\end{array}$} & \multirow[b]{2}{*}{$\begin{array}{c}\text { Percent } \\
\text { Recovered } \\
\text { in FDR }\end{array}$} & \multicolumn{3}{|c|}{$\begin{array}{c}\text { Recoveries } \\
\text { B } \mid \text { Iw Grand Coule } \\
\end{array}$} \\
\hline & & & & & & $\begin{array}{c}\text { Number } \\
\text { Recovered } \\
\text { in Rufus } \\
\text { Woods }\end{array}$ & $\begin{array}{c}\text { Number } \\
\text { Recovered } \\
\text { at Rock Is. } \\
\text { or McNary }\end{array}$ & $\begin{array}{c}\text { Percent } \\
\text { Recovered } \\
\text { Below } \\
\text { FDR }\end{array}$ \\
\hline May 90 & 459 & 17 & $4 \%$ & 14 & $82 \%$ & 2 & 1 & $18 \%$ \\
\hline Mar. 92 & 998 & 16 & $2 \%$ & 16 & $100 \%$ & 0 & 0 & $0 \%$ \\
\hline Apr. 92 & 998 & 31 & $3 \%$ & 29 & $94 \%$ & 2 & 0 & $6 \%$ \\
\hline May 92 & 1,000 & 50 & $5 \%$ & 48 & $96 \%$ & 2 & 0 & $4 \%$ \\
\hline Mar. 93 & 1,994 & 5 & $<1 \%$ & 4 & $80 \%$ & 1 & 0 & $20 \%$ \\
\hline Apr. 93 & 2,000 & 1 & $<1 \%$ & 1 & $100 \%$ & 0 & 0 & $0 \%$ \\
\hline May 93 & 2,000 & 15 & $1 \%$ & 13 & $87 \%$ & 2 & 0 & $13 \%$ \\
\hline
\end{tabular}


recovered below Grand Coulee Dam has ranged from 0 to $63 \%$ over the past five years when releases were grouped monthly (Table 27). This data supports the theory that fish released later in the year have an increased chance of remaining in the reservoir. When early releases axe paired with high water retention times, decreased entrainment levels are observed in both 1992 and 1993. A smoltification type process in Lake Roosevelt net-pen fish and low water retention times are thought to be major factors influencing entrainment (Peone, et al. 1990).

Recovery rates for 1993 released fish in March, April, May, and June, were 93, 100,97 , and $100 \%$ respectively in Lake Roosevelt. In 1993, recovery rates for fish caught in Lake Roosevelt were 98,94, and 99\% for releases of fish in March, April, and May of that year.

Higher water retention times, and release time are important factors of keeping the fish within the reservoir. Clearly the longer fish remain in net-pens, the higher probability that the fish will remain in the reservoir. The Lake Roosevelt Monitoring Program's 1993 annual report contains creel data and pressure estimate changes over the duration of both project. That data is not incorporated into this report. 
Table 27. Summary of rainbow trout release times, water retention times and subsequent recapture numbers and percentages.

\begin{tabular}{|c|c|c|c|c|c|c|c|c|c|}
\hline \multirow[b]{2}{*}{$\begin{array}{c}\text { Release } \\
\text { Date }\end{array}$} & \multirow[b]{2}{*}{$\begin{array}{c}\text { Waler } \\
\text { Retention } \\
\text { Time }\end{array}$} & \multirow[b]{2}{*}{$\begin{array}{c}\text { Total No. } \\
\text { Tagged }\end{array}$} & \multirow[b]{2}{*}{$\begin{array}{l}\text { Total No. } \\
\text { Recovered }\end{array}$} & \multirow[b]{2}{*}{$\begin{array}{c}\text { Percent } \\
\text { Recovered }\end{array}$} & \multirow[b]{2}{*}{$\begin{array}{l}\text { Number } \\
\text { Recovered } \\
\text { in FDR }\end{array}$} & \multirow[b]{2}{*}{$\begin{array}{l}\text { Percent } \\
\text { Recovered } \\
\text { in FDR }\end{array}$} & \multicolumn{2}{|c|}{$\begin{array}{c}\text { Recoveries } \\
\text { Below Grand Cou }\end{array}$} & \multirow[b]{2}{*}{$\begin{array}{l}\text { ee } \\
\text { Percent } \\
\text { Recovered } \\
\text { Below } \\
\text { FDR }\end{array}$} \\
\hline & & & & & & & $\begin{array}{l}\text { Number } \\
\text { Recovered } \\
\text { in Rufus } \\
\text { Woods }\end{array}$ & $\begin{array}{l}\text { Number } \\
\text { Recovered } \\
\text { at Rock Is. } \\
\text { or McNary }\end{array}$ & \\
\hline $\begin{array}{l}\text { Mar. } 89 \\
\text { Mar. } 90 \\
\text { Mar. } 92 \\
\text { Mar. } 93 \\
\end{array}$ & $\begin{array}{l}32 \\
48\end{array}$ & $\begin{array}{c}768 \\
5,9991,441 \\
\\
7,974 \\
\end{array}$ & $\begin{array}{r}8 \\
1077 \\
15 \\
\end{array}$ & $\begin{array}{c}1 \% \\
0 \% \\
2 \% \\
<1 \% \\
\end{array}$ & $\begin{array}{c}3 \\
4 \\
105 \\
14 \\
\end{array}$ & $\begin{array}{l}38 \% \\
57 \% \\
98 \% \\
93 \% \\
\end{array}$ & $\begin{array}{l}0 \\
0 \\
2 \\
1 \\
\end{array}$ & $\begin{array}{l}5 \\
3 \\
0 \\
0 \\
\end{array}$ & $\begin{array}{c}63 \% \\
43 \% \\
2 \% \\
0 \\
\end{array}$ \\
\hline $\begin{array}{l}\text { Apr. } 89 \\
\text { Apr. } 90 \\
\text { Apr. } 91 \\
\text { Apr. } 92 \\
\text { Apr. } 93 \\
\end{array}$ & $\begin{array}{l}33 \\
31 \\
18 \\
51\end{array}$ & $\begin{array}{l}1,470985 \\
2,300 \\
5,998 \\
7.992 \\
\end{array}$ & $\begin{array}{r}20 \\
52 \\
20878 \\
48 \\
\end{array}$ & $\begin{array}{l}2 \% \\
4 \% \\
3 \% \\
3 \% \\
1 \% \\
\end{array}$ & $\begin{array}{c}11 \\
38 \\
52 \\
204 \\
48 \\
\end{array}$ & $\begin{array}{l}55 \% \\
73 \% \\
67 \% \\
98 \% \\
100 \% \\
\end{array}$ & $\begin{array}{c}3 \\
10 \\
13 \\
4 \\
0 \\
\end{array}$ & $\begin{array}{c}6 \\
4 \\
13 \\
0 \\
0 \\
\end{array}$ & $\begin{array}{c}45 \% \\
27 \% \\
33 \% \\
2 \% \\
0 \\
\end{array}$ \\
\hline $\begin{array}{l}\text { May } 88 \\
\text { May } 90 \\
\text { May 92 } \\
\text { May 93 } \\
\end{array}$ & $\begin{array}{l}40 \\
29 \\
34\end{array}$ & $\begin{array}{l}1,171 \\
1,450 \\
6,000 \\
4,999 \\
\end{array}$ & $\begin{array}{c}99 \\
54 \\
295 \\
66 \\
\end{array}$ & $\begin{array}{l}9 \% \\
4 \% \\
1 \% \\
\end{array}$ & $\begin{array}{r}99 \\
44 \\
\\
643 \\
\end{array}$ & $\begin{array}{l}100 \% \\
81 \% \\
97 \% \\
\end{array}$ & $\begin{array}{r}0 \\
8 \\
12 ! \\
\end{array}$ & $\begin{array}{l}0 \\
2 \\
0 \\
0 \\
\end{array}$ & $\begin{array}{c}0 \% \\
19 \% \\
1 \% \\
0 \\
\end{array}$ \\
\hline $\begin{array}{l}\text { Jun. } 91 \\
\text { Jun. } 92 \\
\text { Jun. } 93 \\
\end{array}$ & $\begin{array}{l}29 \\
34\end{array}$ & $\begin{array}{c}296 \\
3,000 \\
296 \\
\end{array}$ & $\begin{array}{c}32 \\
139 \\
11 \\
\end{array}$ & $\begin{array}{l}11 \% \\
5 \% \\
4 \% \\
\end{array}$ & $\begin{array}{c}27 \\
139 \\
11 \\
\end{array}$ & $\begin{array}{l}99 \% \\
100 \% \\
100 \% \\
\end{array}$ & $\begin{array}{l}5 \\
0 \\
0 \\
\end{array}$ & $\begin{array}{l}0 \\
0 \\
0 \\
\end{array}$ & $\begin{array}{c}1 \% \\
0 \% \\
0 \\
\end{array}$ \\
\hline Jul. 91 & 62 & 1,749 & 155 & $9 \%$ & 148 & $97 \%$ & 7 & 0 & $3 \%$ \\
\hline
\end{tabular}




\section{RECOMMENDATIONS}

1. The effects of reservoir drawdowns should be thoroughly studied to determine the impact upon the reservoir's biota.

2. Continue to collect zooplankton and water quality data to build into a model.

3. Continue tagging during a period of stable elevation, at sites producing the most returns.

4. Coordinate with the Lake Roosevelt Monitoring Program to develop biological rule curves for Lake Roosevelt. 


\section{Literature Citations}

APHA. 1976. Standard Methods for the Examination of Water and Wastewater, 14th Ed. American Public Health Association. Washington, D.C. 1192 pp.

Borror, D. J., D.M. Delong, C.A. Triplehorn. 1976. An introduction to the study-of insects. 4th ed. Holt, Rinehart, and Winston. 852 pp.

Bowler, B., B.E. Reiman, and V.L. Ellis. 1979. Pend Oreilee Lake fisheries investigations. Idaho Department of Fish and Game, Job Performance Report, Project F-73-R1, Boise.

Brandlova, J., Z. Brandl and C.H. Fernando. 1972. The Cladocera of Ontario with remarks on some species and distribution. Can. J. of Zool. 50: 1373-1403.

Brooks, J.L. 1957. The systematics of North America Daphnia. Conn. Acad. Arts and Sci. Vol. 13, New Haven, CT. 180 pp.

Chisholm, I, M.E. Hensler, B. Hansen, and D. Skaar. 1989. Quantification of Libby Reservoir levels needed to maintain or enhance reservoir fisheries. Methods of data summary: 1983-1987. Prepared for Bonneville Power Administration, project no. 83-467 by Montana Department of Fish, Wildlife and Parks, Kalispell, MT. 135 pp.

CBFWA. 1993. Fish Passage Center of the Columbia Basin Fish and Wildlife Authority, 1991 annual report.

CRWMR. 1992. Columbia River Water Management Report. Columbia River Water Management Group, Portland, OR. 167 pp.

Downing, J.A. and F.H. Rigler. 1984. A Manual on Methods for the Assessment of Secondary Productivity in Fresh Waters. 2nd. Ed. IBP Handbook No. 17:500.

Edmonds, G.F., S.L. Jensen, and L. Berner. 1976. The Mayflies of North and Central America. University of Minnesota Press. Minneapolis, MN. 330 pp.

Edmondson, W.T. (ed). 1959. Fresh-water Biology. 2nd. ed. John Wiley and Sons. New York. 1248 pp.

Edmondson, W.T. and G.G. Winberg. 1971. A Manual for the Assessment of Secondary Productivity in Fresh Waters. IBP Handbook No. 17. 358 pp.

Griffith, J.R. and A.T. Scholz. 1991. Lake Roosevelt fisheries monitoring program. annual report, 1990. Prepared for Bonneville Power Administration, DE-817988B P91819, by Upper Columbia United Tribes Fisheries Center. Eastern Washington University. Cheney, WA.

Griffith, J.R., A.C. McDowell, and A.T. Scholz. 1993. Measurement of Lake Roosevelt biota in relation to reservoir operations, 1991 annual report. Prepared for Bonneville Power Administration, project no. 88-63, by the Spokane Tribal Fish and Wildlife Center, Wellpinit, WA. $138 \mathrm{pp}$. 
Griffith, J.R., and A.C. McDowell. 1995. Measurement of Lake Roosevelt biota in relation to reservoir operations, 1992 annual report. Prepared for Bonneville Power Administration, project no. 88-63, by the Spokane Tribal Fish and Wildlife Center, Wellpinit, WA.

Maiolie, M.A. and S. Elam. 1993. Report on the experimental trawling of LakeRoosevelt. Idaho Department of Fish and Game. Coeur d'Alene, ID

May, B., S. Glutting, T. Weaver, G. Michael, B. Morgan, P. Suek, J. Wachsmuth, and C. Weichler. 1988. Quantification of Hungry Horse Reservoir water level needed to maintain or enhance reservoir fisheries. Methods and data summary: 1983-1987. Prepared for Bonneville Power Administration, project no. 83-465 by Montana Department of Fish, Wildlife and Parks, Kalispell, MT. 148 pp.

Merritt, R.W. and K.W. Cummins. 1984. An Introduction to the Aquatic Insects of North America. Kendell-Hunt, Dubuque, IA. 722 pp.

Oliver, D.R. 1971. Life history of the Chironomidae. Annual Review of Entomology. 16:211-230.

Pennak, R.W. 1978. Freshwater Invertebrates of the United States, 2nd ed. Wiley and sons, New York. 803 pp.

Pennak, R.W. 1989. Freshwater Invertebrates of the United States, 3rd ed. Wiley and sons, New York. 628 pp.

Rieman, B.E. 1992. Kokanee salmon population dynamics-kokanee salmon monitoring guidelines. Idaho Department of Fish and Game, Job Performance Report, Project F-73-R-14, Subproject II, Study II, Boise.

Rigler, F. H. 1978. Sugar frosted Daphnia; An improved fixation technique for Cladocera. Limnol. Oceanogr. 23(3):557-559.

Ruttner-Kolisko, A. 1974. Plankton Rotifers Biology and Taxonomy. Die Binnengewasser, Stutgart. 26/1. 146 pp.

Stemberger, R.S. 1979. A guide to rotifers of the Laurentian Great Lakes. Environmental Monitoring and Support Laboratory, office of Research and Development, U.S. Environmental Protection Agency, Cincinnati, OH. EPA-600/4-79-021. 1985 pp.

Stober, Q.J., M.E. Kopache and T.H. Jagielo. 1981. The limnology of Lake Roosevelt. Final Report Contract No. 14-16-0009-80-0004, to the U.S. Fish and Wildlife Service. National Fisheries Research Center, Seattle, WA. Fisheries Research Institute, University of Washington, Seattle, WA. FRI-VW-8 106: 116 pp.

U. S. Army Corps of Engineers. 1993. Reservoir storage tables for Grand Coulee Reservoir. Prepared from table by U.S. Bureau of Reclamation and U. S . Geological Survey. October 1977.

U.S. Bureau of Reclamation. 1977. Franklin D. Roosevelt Lake area-capacity tables. U. S. Department of Interior by U.S. Bureau of Reclamation and U.S. Geological Survey, Boise, ID. 
Ward, J. 1955. A description of a new zooplankton counter. Quart. J. Microscop. Scien. 96:37 1-373.

Ward, H.B. and G.C. Whipple. 1966. Freshwater Biology, 2nd Ed. John Whiley and Sons, New York. 1248pp.

Weber, C.I. (ed.). 1973. Biological field and laboratory methods for measuring the quality of surface waters and effluents. NERC/EPA, Cincinnati, Ohio. 176 pp.

Wiggins, G.B. 1977. Larvae of the North American Caddisfly Genera (Trichoptera). University of Toronto. Toronto, ONT: $568 \mathrm{pp}$.

Woods, P.F. 1982. Annual nutrient loadings, primary productivity. and trophic state of Lake Koocanusa, Montana and British Columbia, 1972-80. In May, B. et al. Quantification of Hungry Horse Reservoir water level needed to maintain or enhance reservoir fisheries, 1983-87. Prepared for Bonneville Power Administration, project no. 83-465 by Montana Department of Fish, Wildlife and Parks, Kalispell, MT. 
APPENDIX A

HYDROLOGY 
Table A.1 Daily midnight reservoir inflow, outflow, elevation, storage capacity, and water retention time for Lake Roosevelt in January, 1993. Data from CORPs daily summary reports.

\begin{tabular}{|c|c|c|c|c|c|}
\hline \multicolumn{6}{|c|}{ JANUARY } \\
\hline $\begin{array}{c}\text { DAY } \\
\text { OF } \\
\text { MONTH }\end{array}$ & $\begin{array}{c}\text { INFLOW } \\
\text { (KCFS) }\end{array}$ & $\begin{array}{l}\text { OUTFLOW } \\
\text { (KCFS) }\end{array}$ & \begin{tabular}{|c} 
RESERVOIR \\
ELEVATION \\
(FT)
\end{tabular} & $\begin{array}{l}\text { STORAGE } \\
\text { CAPACITY } \\
\text { ( K C F S D ) }\end{array}$ & $\begin{array}{c}\text { WATER } \\
\text { RETENTION } \\
\text { TIME (D) }\end{array}$ \\
\hline 1 & 97.80 & 96.00 & $1,272.80$ & $3,922.40$ & 40.86 \\
\hline 2 & 94.10 & 116.20 & $1,272.20$ & $3,900.30$ & 33.57 \\
\hline 3 & 90.90 & 112.90 & $1,271.60$ & $3,878.30$ & 34.35 \\
\hline 4 & 95.00 & 138.80 & $1,270.40$ & $3,834.50$ & 27.63 \\
\hline 5 & 98.70 & 140.40 & $1,269.30$ & $3,794.60$ & 27.03 \\
\hline 6 & 114.00 & 148.20 & $1,268.30$ & $3,758.50$ & 25.36 \\
\hline 7 & 125.90 & 152.80 & $1,267.60$ & $3,733.40$ & 24.43 \\
\hline 8 & 127.90 & 126.10 & $1,267.60$ & $3,733.40$ & 29.61 \\
\hline 9 & 123.80 & 113.10 & $1,267.90$ & $3,744.20$ & 33.11 \\
\hline 10 & 119.80 & 123.10 & $1,267.80$ & $3,740.60$ & 30.39 \\
\hline 11 & 112.00 & 133.50 & $1,267.20$ & $3,719.10$ & 27.86 \\
\hline 12 & 109.70 & 134.80 & $1,266.50$ & $3,694.10$ & 27.40 \\
\hline 13 & 97.80 & 126.20 & $1,265.70$ & $3,701.20$ & 29.33 \\
\hline 14 & 100.10 & 103.60 & $1,267.60$ & $3,737.00$ & 36.07 \\
\hline 15 & 94.30 & 96.00 & $1,265.60$ & $3,664.60$ & 38.17 \\
\hline 16 & 93.80 & 86.70 & $1,265.80$ & $3,669.20$ & 42.32 \\
\hline 17 & 91.10 & 78.77 & $1,266.10$ & $3,679.80$ & 46.72 \\
\hline 18 & 92.10 & 106.30 & $1,265.70$ & $3,664.60$ & 34.47 \\
\hline 19 & 93.20 & 98.60 & $1,265.55$ & $3,658.50$ & 37.10 \\
\hline 20 & 79.10 & 63.10 & $1,266.00$ & $3,676.30$ & 58.26 \\
\hline 21 & 94.60 & 94.60 & $1,266.00$ & $3,676.30$ & 38.86 \\
\hline 22 & 80.80 & 87.90 & $1,265.80$ & $3,669.20$ & 41.74 \\
\hline 23 & 84.60 & 95.20 & $1,265.50$ & $3,658.50$ & 38.43 \\
\hline 24 & 84.70 & 63.40 & $1,266.10$ & $3,679.80$ & 58.04 \\
\hline 25 & 86.00 & 68.20 & $1,266.60$ & $3,697.60$ & 54.22 \\
\hline 26 & 88.60 & 72.60 & $1,267.05$ & $3,711.90$ & 51.13 \\
\hline 27 & 83.10 & 77.70 & $1,267.20$ & $3,719.10$ & 47.86 \\
\hline 28 & 83.90 & 73.00 & $1,267.50$ & $3,729.80$ & 51.09 \\
\hline 29 & 71.30 & 73.10 & $1,267.40$ & $3,726.20$ & 50.97 \\
\hline 30 & 70.70 & 58.10 & $1,267.80$ & $3,740.60$ & 64.38 \\
\hline 31 & 66.10 & 57.10 & $1,268.00$ & $3,776.50$ & 66.14 \\
\hline Totals & 95.0 & 100.5 & $1,267 . \mathrm{S}$ & $3,731.9$ & 40.2 \\
\hline
\end{tabular}


Table A.2 Daily midnight reservoir inflow, outflow, elevation, storage capacity, and water retention time for Lake Roosevelt in February, 1993.- Data from CORPs daily summary reports.

\begin{tabular}{|c|c|c|c|c|c|}
\hline \multicolumn{6}{|c|}{ FEBRUARY } \\
\hline $\begin{array}{c}\text { DAY } \\
\text { OF } \\
\text { MO1TH }\end{array}$ & $\begin{array}{c}\text { INFLOW } \\
\text { (KCFS) }\end{array}$ & $\begin{array}{c}\text { OUTFLOW } \\
\text { (KCFS) }\end{array}$ & $\begin{array}{l}\text { RESERVOIR } \\
\text { ELEVATION } \\
\text { (FT) }\end{array}$ & $\begin{array}{c}\text { STORAGE } \\
\text { CAPACITY } \\
\text { (KCFSD) }\end{array}$ & $\begin{array}{l}\text { WATER } \\
\text { RETENTION } \\
\text { TIME (D) }\end{array}$ \\
\hline 2 & 75.4074 .80 & 95.1085 .50 & $1,267.201,267.50$ & $3,719,103,729.80$ & 43.5039 .22 \\
\hline 3 & 77.80 & 95.70 & $1,266.70$ & $3,701.20$ & 38.68 \\
\hline 4 & 74.60 & 76.40 & $1,266.60$ & $3,697.60$ & 48.40 \\
\hline 5 & 76.70 & 71.40 & $1,266.80$ & $3,704.80$ & 51.89 \\
\hline 6 & 80.30 & 55.30 & $1,267.50$ & $3,729.80$ & 67.45 \\
\hline 7 & 72.20 & 63.30 & $1,267.70$ & $3,737.00$ & 59.04 \\
\hline $\begin{array}{l}8 \\
9\end{array}$ & 71.0065 .40 & 70.8083 .50 & $1,267201,267.40$ & 3726.203 .719 .10 & 44.6352 .53 \\
\hline 10 & 69.80 & 71.60 & $1,267.20$ & $3,719.10$ & 51.94 \\
\hline 11 & & & & & \\
\hline 12 & 70.7066 .50 & 70.1083 .30 & $1,266.8001,266.70$ & $3,704.803,701.20$ & 44.4852 .80 \\
\hline 13 & 61.60 & 56.20 & $1,266.90$ & $3,708.40$ & 65.99 \\
\hline 15 & 63.60 & 69.00 & $1,266.70$ & $3,701.20$ & 53.64 \\
\hline 16 & 62.1060 .30 & 120.4097 .70 & $1,265.701,264.00$ & $3,664,603,605.60$ & 29.9537 .51 \\
\hline 17 & 69.70 & 111.60 & $1,262.80$ & $3,563.50$ & 31.93 \\
\hline 18 & 84.70 & 116.10 & $1,261.90$ & $3,532.90$ & 30.43 \\
\hline 19 & 84.00 & 108.20 & $1,261.20$ & $3,507.80$ & 32.42 \\
\hline 20 & & & & & \\
\hline $\begin{array}{l}21 \\
22\end{array}$ & 74.0066 .40 & 76.8084 .40 & $1,260.601,260.90$ & $3,497.403,487,00$ & 41.4445 .40 \\
\hline 23 & 73.6074 .60 & 109.60100 .50 & $1,259.901,258.80$ & $3,562,903,425.20$ & 35.4531 .25 \\
\hline 25 & 72.4068 .10 & 104.6095 .30 & $1,257.101,258.00$ & $3,397.903,367.40$ & 35.6532 .19 \\
\hline $\begin{array}{l}20 \\
27\end{array}$ & 77.4075 .00 & 105.9066 .60 & $1,256.201,256.45$ & $3,337.103,343.80$ & 31.5150 .21 \\
\hline 28 & 62.10 & 60.40 & $1,256.50$ & $3,347.20$ & 55.42 \\
\hline Totals & 71.6 & 85.9 & $1,263 . \mathrm{S}$ & $3,594.3$ & 44.1 \\
\hline
\end{tabular}


Table A.3 Daily midnight reservoir inflow, outflow, elevation, storage capacity, and water retention time for Lake Roosevelt in March, 1993. Data from CORPs daily summary reports.

\begin{tabular}{|c|c|c|c|c|c|}
\hline \multicolumn{6}{|c|}{ MARCH } \\
\hline $\begin{array}{c}\text { DAY } \\
\text { OF } \\
\text { MONTH }\end{array}$ & $\begin{array}{c}\text { INFLOW } \\
\text { (KCFS) }\end{array}$ & $\begin{array}{l}\text { OUTFLOW } \\
\text { (KCFS) }\end{array}$ & $\begin{array}{l}\text { IESERVOIR } \\
\text { iLEVATION } \\
\text { (FT) }\end{array}$ & $\begin{array}{l}\text { STORAGE } \\
\text { CAPACITY } \\
\text { ( K C F S D ) }\end{array}$ & $\begin{array}{l}\text { WATER } \\
\text { RETENTION } \\
\text { (TIMD) }\end{array}$ \\
\hline 1 & 63.40 & 97.00 & $1,255.50$ & $3,313.60$ & 34.16 \\
\hline 2 & 56.20 & 74.60 & $1,255.00$ & $3,296.90$ & 44.19 \\
\hline 3 & 58.90 & 63.90 & $1,254.80$ & $3,290.30$ & 51.49 \\
\hline 4 & 58.70 & 67.00 & $1,254.60$ & $3,283.60$ & 49.01 \\
\hline 5 & 53.20 & 54.90 & $1,254.50$ & $3,280.30$ & 59.75 \\
\hline 6 & 52.50 & 44.20 & $1,254.80$ & $3,290.30$ & 74.44 \\
\hline 7 & 46.60 & 38.30 & $1,255.00$ & $3,296.90$ & 86.08 \\
\hline 8 & 59.20 & 57.50 & $1,255.10$ & $3,300.30$ & 57.40 \\
\hline 9 & 54.10 & 62.40 & $1,254.80$ & $3,290.30$ & 52.73 \\
\hline 10 & 56.60 & 54.90 & $1,254.90$ & $3,296.60$ & 60.05 \\
\hline 11 & 60.10 & 51.80 & $1,255.10$ & $3,300.30$ & 63.71 \\
\hline 12 & 58.30 & 53.30 & $1,255.30$ & $3,306.90$ & 62.04 \\
\hline 13 & 50.90 & 42.60 & $1,255.50$ & $3,313.60$ & 77.78 \\
\hline 14 & 50.00 & 36.60 & $1,255.90$ & $3,327.00$ & 90.90 \\
\hline 15 & 53.70 & 67.10 & $1,255.50$ & $3,313.60$ & 49.38 \\
\hline 16 & 57.60 & 69.40 & $1,255.20$ & $3,303.60$ & 47.60 \\
\hline 17 & 53.10 & 51.40 & $1,255.20$ & $3,303.60$ & 64.27 \\
\hline 18 & 54.90 & 43.20 & $1,255.60$ & $3,317.00$ & 76.78 \\
\hline 19 & 60.20 & 45.20 & $1,256.00$ & $3,330.40$ & 73.68 \\
\hline 20 & 45.10 & 38.40 & $1,256.20$ & $3,337.10$ & 86.90 \\
\hline 21 & 49.10 & 37.40 & $1,256.60$ & $3,350.50$ & 89.59 \\
\hline 22 & 45.70 & 67.50 & $1,255.90$ & $3,327.00$ & 49.29 \\
\hline 23 & 49.20 & 59.20 & $1,255.60$ & $3,317.00$ & 56.03 \\
\hline 24 & 61.00 & 61.00 & $1,255.60$ & $3,317.00$ & 54.38 \\
\hline 25 & 58.20 & 49.90 & $1,255.90$ & $3,327,00$ & 66.67 \\
\hline 26 & 63.80 & 40.30 & $1,256.60$ & $3,350.50$ & 83.14 \\
\hline 27 & 68.30 & 29.50 & $1,257.70$ & $3,387.70$ & 114.84 \\
\hline 28 & 69.60 & 25.30 & $1,259.00$ & $3,432.00$ & 135.65 \\
\hline 29 & 68.40 & 70.10 & $1,259.00$ & $3,432.00$ & 48.96 \\
\hline 30 & 71.70 & 68.10 & $1,259.10$ & $3,435.40$ & 50.45 \\
\hline 31 & 63.10 & 49.40 & $1,259.50$ & $3,449.10$ & 69.82 \\
\hline Totals & 57.1 & 53.9 & 1256.0 & 3329.6 & 67.1 \\
\hline
\end{tabular}


Table A.4 Daily midnight reservoir inflow, outflow, elevation, storage capacity, and water retention time for Lake Roosevelt in April, 1993. Data from CORPs daily summary reports.

\begin{tabular}{|c|c|c|c|c|c|}
\hline \multicolumn{7}{|c|}{ APRIL } \\
\hline \hline $\begin{array}{c}\text { DAY } \\
\text { OF }\end{array}$ & $\begin{array}{c}\text { INFLOW } \\
\text { (KCFS) }\end{array}$ & $\begin{array}{c}\text { OUTFLOW } \\
\text { (KCFS) }\end{array}$ & $\begin{array}{c}\text { RESERVOIR } \\
\text { ELEVATION } \\
\text { (KT) }\end{array}$ & $\begin{array}{c}\text { STORAGE } \\
\text { CAPACITY } \\
\text { (KCFSD) }\end{array}$ & $\begin{array}{c}\text { WATER } \\
\text { ZETENTION } \\
\text { T I M E }\end{array}$ \\
\hline 1 & & & D $)$ \\
2 & 72.30 & 48.10 & $1,260.20$ & $3,473.20$ & 72.21 \\
3 & 67.00 & 49.50 & $1,260.70$ & $3,490.50$ & 70.52 \\
4 & 68.60 & 32.30 & $1,261.60$ & $3,521.70$ & 109.03 \\
5 & 73.40 & 23.00 & $1,263.00$ & $3,570.50$ & 155.24 \\
6 & 73.70 & 41.30 & $1,263.90$ & $3,602.00$ & 87.22 \\
7 & 75.30 & 56.00 & $1,264.40$ & $3,619.70$ & 64.64 \\
8 & 66.30 & 41.60 & $1,265.10$ & $3,644.40$ & 87.61 \\
9 & 84.40 & 59.60 & $1,265.80$ & $3,669.20$ & 61.56 \\
10 & 67.80 & 56.70 & $1,266.10$ & $3,679.80$ & 64.90 \\
11 & 82.10 & 39.80 & $1,267.10$ & $3,715.50$ & 93.35 \\
12 & 76.40 & 32.00 & $1,268.15$ & $3,751.30$ & 117.23 \\
13 & 83.70 & 53.90 & $1,268.90$ & $3,780.20$ & 70.13 \\
14 & 81.30 & 59.80 & $1,269.45$ & $3,798.20$ & 63.52 \\
15 & 80.10 & 47.70 & $1,270.30$ & $3,830.90$ & 80.31 \\
16 & 82.00 & 47.70 & $1,271.20$ & $3,863.70$ & 81.00 \\
17 & 77.80 & 47.30 & $1,272.00$ & $3,892.90$ & 82.30 \\
18 & 79.40 & 37.60 & $1,272.90$ & $3,892.90$ & 103.53 \\
19 & 80.40 & 34.70 & $1,274.00$ & $3,966.70$ & 114.31 \\
20 & 76.00 & 51.70 & $1,274.50$ & $3,985.30$ & 77.09 \\
21 & 80.50 & 49.30 & $1,275.30$ & $4,015.10$ & 81.44 \\
22 & 76.40 & 47.00 & $1,275.95$ & $4,037.50$ & 85.90 \\
23 & 75.10 & 56.00 & $1,276.40$ & $4,056.30$ & 72.43 \\
24 & 78.70 & 54.50 & $1,277.00$ & $4,078.90$ & 74.84 \\
25 & 91.90 & 27.90 & $1,278.70$ & $4,143.20$ & 148.50 \\
26 & 93.30 & 26.90 & $1,280.35$ & $4,204.30$ & 156.29 \\
27 & 92.50 & 62.00 & $1,281.10$ & $4,235.20$ & 68.31 \\
28 & 98.90 & 66.60 & $1,281.80$ & $4,262.30$ & 64.00 \\
29 & 88.00 & 80.00 & $1,281.80$ & $4,262.30$ & 53.28 \\
30 & 93.20 & 78.10 & $1,282.00$ & $4,270.10$ & 54.67 \\
Totals & 93.90 & 44.30 & $1,282.90$ & $4,305.20$ & 97.18 \\
\hline & 80.4 & 48.4 & $\mathbf{1 , 2 7} 1.8$ & $\mathbf{3 , 8 8 7 . 3}$ & 87.1 \\
\hline
\end{tabular}


Table A.5 Daily midnight reservoir inflow, outflow, elevation, storage capacity, and water retention time for Lake . Roosevelt in May, 1993. Data from CORPs daily summary reports.

\begin{tabular}{|c|c|c|c|c|c|}
\hline \multicolumn{7}{|c|}{ MAY } \\
\hline \hline $\begin{array}{c}\text { DAY } \\
\text { OF }\end{array}$ & $\begin{array}{c}\text { INFLOW } \\
\text { (KCFS) }\end{array}$ & $\begin{array}{c}\text { OUTFLOW } \\
\text { (KCFS) }\end{array}$ & $\begin{array}{c}\text { RESERVOIR } \\
\text { ELEVATION }\end{array}$ & $\begin{array}{c}\text { STORAGE } \\
\text { CAPACITY } \\
\text { (FT) }\end{array}$ & $\begin{array}{c}\text { WATER } \\
\text { RETENTION } \\
\text { TIME (D) }\end{array}$ \\
\hline 1 & & & & C D $)$ & TIME. \\
2 & 86.40 & 65.00 & $1,283.10$ & $4,313.10$ & 66.36 \\
3 & 86.70 & 57.40 & $1,283.50$ & $4,328.80$ & 75.41 \\
4 & 92.20 & 102.80 & $1,283.00$ & $4,309.10$ & 41.92 \\
5 & 91.60 & 75.60 & $1,283.30$ & $4,320.90$ & 57.15 \\
6 & 98.10 & 88.70 & $1,283.40$ & $4,324.80$ & 48.76 \\
7 & 97.80 & 90.00 & $1,283.40$ & $4,324.80$ & 48.05 \\
8 & 107.30 & 94.80 & $1,283.60$ & $4,332.70$ & 45.70 \\
9 & 108.50 & 90.60 & $1,283.80$ & $4,340.60$ & 47.91 \\
10 & 103.80 & 110.60 & $1,283.50$ & $4,328.80$ & 39.14 \\
11 & 104.20 & 115.00 & $1,283.10$ & $4,313.10$ & 37.51 \\
12 & 111.80 & 122.50 & $1,282.70$ & $4,297.40$ & 35.08 \\
13 & 125.20 & 124.20 & $1,282.60$ & $4,293.50$ & 34.57 \\
14 & 139.70 & 99.50 & $1,283.50$ & $4,328.80$ & 43.51 \\
15 & 150.50 & 79.70 & $1,285.20$ & $4,396.20$ & 55.16 \\
16 & 146.60 & 130.30 & $1,285.30$ & $4,400.20$ & 33.77 \\
17 & 149.70 & 123.40 & $1,285.70$ & $4,416.20$ & 35.79 \\
18 & 145.10 & 141.00 & $1,285.60$ & $4,412.20$ & 31.29 \\
19 & 155.30 & 150.80 & $1,285.50$ & $4,408.20$ & 29.23 \\
20 & 156.30 & 151.90 & $1,285.40$ & $4,404.20$ & 28.99 \\
21 & 158.10 & 143.70 & $1,285.60$ & $4,412.20$ & 30.70 \\
22 & 166.10 & 147.20 & $1,285.80$ & $4,420.20$ & 30.03 \\
23 & 168.80 & 162.60 & $1,285.65$ & $4,412.20$ & 27.14 \\
24 & 165.00 & 151.10 & $1,285.70$ & $4,416.20$ & 29.23 \\
25 & 156.60 & 157.50 & $1,285.50$ & $4,408.20$ & 27.99 \\
26 & 147.20 & 160.60 & $1,285.00$ & $4,388.20$ & 27.32 \\
27 & 154.50 & 145.10 & $1,285.10$ & $4,392.20$ & 30.27 \\
28 & 147.40 & 130.60 & $1,285.40$ & $4,404.20$ & 33.72 \\
29 & 144.20 & 115.00 & $1,286.00$ & $4,428.30$ & 38.51 \\
30 & 145.70 & 135.20 & $1,286.10$ & $4,432.30$ & 32.78 \\
31 & 148.20 & 111.40 & $1,286.80$ & $4,460.50$ & 40.04 \\
TotaIs & 133.00 & 114.30 & $1,287.00$ & $4,468.60$ & 39.10 \\
\hline & 132.0 & 119.0 & 1284.7 & 4375.4 & 39.4 \\
\hline
\end{tabular}


Table A.6 Daily midnight reservoir inflow, outflow, elevation, storage capacity, and water retention time for Lake Roosevelt in June, 1993. Data from CORPs daily summary reports.

\begin{tabular}{|c|c|c|c|c|c|}
\hline \multicolumn{6}{|c|}{ JUNE } \\
\hline $\begin{array}{c}\text { DAY } \\
\text { OF } \\
\text { MONTH }\end{array}$ & $\begin{array}{c}\text { INFLOW } \\
\text { (KCFS) }\end{array}$ & $\begin{array}{c}\text { OUTFLOW } \\
\text { (KCFS) }\end{array}$ & $\begin{array}{c}\text { TRESERVOIR } \\
\text { ELEVATION } \\
\text { (FT) }\end{array}$ & $\begin{array}{l}\text { STORAGE } \\
\text { CAPACITY } \\
\text { (KCFSD) }\end{array}$ & $\begin{array}{c}\text { WATER } \\
\text { RETENTION } \\
\text { T IME (D) }\end{array}$ \\
\hline 1 & 135.60 & 116.50 & $1,287.40$ & $4,484.80$ & 38.50 \\
\hline 2 & 141.20 & 136.00 & $1,287.40$ & $4,484.80$ & 32.98 \\
\hline 3 & 131.80 & 132.60 & $1,287.30$ & $4,480.80$ & 33.79 \\
\hline 4 & 125.60 & 126.00 & $1,287.20$ & $4,476.70$ & 35.53 \\
\hline 5 & 124.00 & 105.10 & $1,287.30$ & $4,480.80$ & 42.63 \\
\hline 6 & 114.20 & 80.90 & $1,288.15$ & $4,513.40$ & 55.79 \\
\hline 7 & 112.30 & 101.30 & $1,288.30$ & $4,521.50$ & 44.63 \\
\hline 8 & 111.10 & 98.10 & $1,288.30$ & $4,521.50$ & 46.09 \\
\hline 9 & 98.60 & 116.30 & $1,288.00$ & $4,509.30$ & 38.77 \\
\hline 10 & 100.00 & 125.70 & $1,287.20$ & $4,476.70$ & 35.61 \\
\hline 11 & 93.00 & 121.00 & $1,286.40$ & $4,444.40$ & 36.73 \\
\hline 12 & 94.10 & 67.50 & $1,286.80$ & $4,460.50$ & 66.08 \\
\hline 13 & 91.70 & 59.10 & $1,287.30$ & $4,480.80$ & 75.82 \\
\hline 14 & 95.40 & 75.60 & $1,287.60$ & $4,493.00$ & 59.43 \\
\hline 15 & 93.40 & 74.50 & $1,287.90$ & $4,505.20$ & 60.47 \\
\hline 16 & 92.40 & 83.70 & $1,288.00$ & $4,509.30$ & 53.87 \\
\hline 17 & 89.40 & 80.60 & $1,288.00$ & $4,509.30$ & 55.95 \\
\hline 18 & 84.40 & 85.10 & $1,287.80$ & $4,501.10$ & 52.89 \\
\hline 19 & 86.50 & 68.10 & $1,288.00$ & $4,509.30$ & 66.22 \\
\hline 20 & 86.20 & 59.50 & $1,288.30$ & $4,521.50$ & 75.99 \\
\hline 21 & 89.80 & 94.10 & $1,288.00$ & $4,509.30$ & 47.92 \\
\hline 22 & 90.10 & 91.60 & $1,287.80$ & $4,501.10$ & 49.14 \\
\hline 23 & 92.20 & 103.90 & $1,287.40$ & $4,484.80$ & 43.16 \\
\hline 24 & 91.10 & 90.60 & $1,287.20$ & $4,476.70$ & 49.41 \\
\hline 25 & 95.50 & 80.10 & $1,287.40$ & $4,484.80$ & 55.99 \\
\hline 26 & 89.80 & 87.70 & $1,287.20$ & $4,476.70$ & 51.05 \\
\hline 27 & 94.20 & 71.80 & $1,287.40$ & $4,484.80$ & 62.46 \\
\hline 28 & 87.50 & 101.80 & $1,286.90$ & $4,464.60$ & 43.86 \\
\hline 29 & 98.20 & 109.80 & $1,286.40$ & $4,444.40$ & 40.48 \\
\hline 30 & 94.60 & 125.50 & $1,285.50$ & $4,408.20$ & 35.13 \\
\hline Totals & 100.80 & 95.67 & $1,287.46$ & $4,487.34$ & 49.55 \\
\hline
\end{tabular}


Table A.7 Daily midnight reservoir inflow, outflow, elevation, storage capacity, and water retention time for Lake Roosevelt in July, 1993. Data from CORPs daily summary reports.

\begin{tabular}{|c|c|c|c|c|c|}
\hline \multicolumn{6}{|c|}{ JULY } \\
\hline $\begin{array}{c}\text { DAY } \\
\text { OF } \\
\text { MONTH }\end{array}$ & $\begin{array}{r}\text { INFLOW } \\
\text { (KCFS) }\end{array}$ & $\begin{array}{l}\text { OUTFLOW } \\
\text { (KCFS) }\end{array}$ & $\begin{array}{l}\text { RESER VOIR } \\
\text { ILEVATION } \\
\text { (FT) }\end{array}$ & $\begin{array}{l}\text { STORAGE } \\
\text { CAPACITY } \\
\text { ( K C F S D ) }\end{array}$ & $\begin{array}{c}\text { WATER } \\
\text { RETENTION } \\
\text { TIME (D) }\end{array}$ \\
\hline 1 & 90.80 & 127.90 & $1,284.50$ & $4,368.30$ & 34.15 \\
\hline 2 & 96.60 & 117.30 & $1,283.90$ & $4,344.60$ & 37.04 \\
\hline 3 & 99.40 & 112.80 & $1,283.20$ & $4,317.00$ & 38.27 \\
\hline 4 & 108.30 & 72.50 & $1,283.80$ & $4,340.60$ & 59.87 \\
\hline 5 & 117.10 & 112.90 & $1,283.60$ & $4,332.70$ & 38.38 \\
\hline 6 & 106.30 & 112.40 & $1,283.30$ & $4,320.90$ & 38.44 \\
\hline 7 & 119.10 & 94.80 & $1,283.70$ & $4,336.70$ & 45.75 \\
\hline 8 & 116.60 & 102.20 & $1,283.90$ & $4,344.60$ & 42.51 \\
\hline 9 & 115.10 & 107.70 & $1,283.90$ & $4,344.60$ & 40.34 \\
\hline 10 & 121.00 & 80.90 & $1,284.70$ & $4,376.30$ & 54.10 \\
\hline 11 & 125.30 & 97.10 & $1,285.10$ & $4,392.20$ & 45.23 \\
\hline 12 & 133.80 & 94.20 & $1,285.90$ & $4,424.20$ & 46.97 \\
\hline 13 & 137.40 & 96.20 & $1,286.80$ & $4,460.50$ & 46.37 \\
\hline 14 & 123.80 & 107.80 & $1,287.00$ & $4,468.60$ & 41.45 \\
\hline 15 & 117.00 & 109.10 & $1,287.10$ & $4,472.70$ & 41.00 \\
\hline 16 & 121.70 & 113.70 & $1,287.20$ & $4,476.70$ & 39.37 \\
\hline 17 & 133.00 & 87.60 & $1,288.10$ & $4,513.40$ & 51.52 \\
\hline 18 & 130.20 & 103.00 & $1,288.60$ & $4,533.80$ & 44.02 \\
\hline 19 & 119.20 & 92.70 & $1,289.10$ & $4,554.40$ & 49.13 \\
\hline 20 & 105.70 & 96.60 & $1,289.20$ & $4,558.50$ & 47.19 \\
\hline 21 & 103.10 & 97.30 & $1,289.20$ & $4,558.50$ & 46.85 \\
\hline 22 & 96.40 & 94.60 & $1,289.20$ & $4,558.50$ & 48.19 \\
\hline 23 & 82.30 & 100.50 & $1,288.70$ & $4,537.90$ & 45.15 \\
\hline 24 & 84.00 & 75.20 & $1,288.70$ & $4,537.90$ & 60.34 \\
\hline 25 & 77.70 & 64.80 & $1,288.70$ & $4,537.90$ & 70.03 \\
\hline 26 & 82.80 & 89.10 & $1,288.50$ & $4,529.70$ & 50.84 \\
\hline 27 & 78.90 & 94.20 & $1,288.00$ & $4,509.30$ & 47.87 \\
\hline 28 & 65.70 & 105.60 & $1,286.90$ & $4,464.60$ & 42.28 \\
\hline 29 & 69.10 & 93.90 & $1,286.20$ & $4,436.30$ & 47.24 \\
\hline 30 & 76.90 & 92.60 & $1,285.70$ & $4,416.20$ & 47.69 \\
\hline 31 & 71.20 & 67.20 & $1,285.60$ & $4,412.20$ & 65.66 \\
\hline Totals & $104.0 \mathrm{~s}$ & 97.24 & $1,286.39$ & $4,444.53$ & 46.88 \\
\hline
\end{tabular}


Table A.8 Daily midnight reservoir inflow, outflow, elevation, storage capacity, and water retention time for Lake Roosevelt in August, 1993. Data from CORPs daily summary reports.

\begin{tabular}{|c|c|c|c|c|c|}
\hline \multicolumn{6}{|c|}{ August } \\
\hline $\begin{array}{c}\text { DAY } \\
\text { OF } \\
\text { MONTH }\end{array}$ & $\begin{array}{c}\text { INFLOW } \\
\text { (KCFS) }\end{array}$ & $\begin{array}{c}\text { OUTFLOW } \\
\text { (KCFS) }\end{array}$ & $\begin{array}{c}\text { RESERVOIR } \\
\text { ELEVATION } \\
\text { (FT) }\end{array}$ & $\begin{array}{l}\text { STORAGE } \\
\text { CAPACITY } \\
\text { (KCFSD) }\end{array}$ & $\begin{array}{c}\text { WATER } \\
\text { RETENTION } \\
\text { TIME (D) }\end{array}$ \\
\hline 1 & & & & & \\
\hline 2 & 91.3081 .60 & 76.6060 .70 & $1,287.30$ & $4,480.80$ & 58.3473 .82 \\
\hline 3 & 80.90 & 98.30 & $1,286.70$ & $4,456.50$ & 45.34 \\
\hline 4 & 78.70 & 81.80 & $1,286.50$ & $4,448.40$ & 54.38 \\
\hline 5 & 81.20 & 82.30 & $1,286.30$ & $4,440.30$ & 53.95 \\
\hline 6 & 78.40 & 81.50 & $1,286.10$ & $4,432.30$ & 54.38 \\
\hline 8 & 81.90 & 76.40 & $1,286.10$ & $4,432.30$ & 58.01 \\
\hline 9 & 73.9098 .20 & 55.3057 .30 & $\begin{array}{l}1,286.30 \\
1287.10\end{array}$ & $4,440.30$ & 78.0680 .29 \\
\hline 10 & 99.40 & 109.20 & $1,286.70$ & $4,456.50$ & 40.81 \\
\hline 11 & 95.40 & 98.40 & $1,286.50$ & 4448.40 & 45.21 \\
\hline 12 & & & & & \\
\hline 13 & 96.6091 .60 & 92.7087 .60 & $1,286.40$ & $4,444.40$ & 50.8347 .94 \\
\hline 14 & 89.40 & 101.70 & $1,286.00$ & $4,428.30$ & 43.54 \\
\hline 17 & $92,3080.10$ & 82.2083 .80 & $1,285.70$ & $4,416.20$ & 53.8752 .70 \\
\hline 18 & 81.9085 .00 & 112.30109 .10 & $1,284.80$ & $4,380.30$ & 39.8639 .01 \\
\hline 19 & & & & & \\
\hline 21 & 91.5089 .80 & 98.4084 .60 & $1,283.70$ & $4,336.70$ & 44.0751 .26 \\
\hline 22 & 89.7084 .90 & 74.6058 .40 & $\begin{array}{l}1,283.90 \\
1,284.30\end{array}$ & $\begin{array}{l}4,344.60 \\
4360.40\end{array}$ & 74.6658 .24 \\
\hline 24 & 99.2089 .40 & 49.0074 .20 & $1,285.10$ & $4,392.20$ & 59.4189 .64 \\
\hline & & & $1,285.50$ & & \\
\hline 26 & 91.60 & 74.60 & $1,285.80$ & $4,420.20$ & 59.25 \\
\hline $\begin{array}{l}27 \\
28\end{array}$ & 1007092,00 & 91.1087 .70 & $\begin{array}{l}1,286.00 \\
1,285.90\end{array}$ & $\begin{array}{l}4,428.30 \\
4,424.20\end{array}$ & 48.5650 .49 \\
\hline 29 & 93.0093 .60 & 79.8056 .50 & $1,286.10$ & $4,432.30$ & 79.0255 .54 \\
\hline & & & $1,286.90$ & $4,464.60$ & \\
\hline $\begin{array}{l}30 \\
31\end{array}$ & 67008250 & 97106040 & 128 & 444410 & 74101577 \\
\hline$\frac{\text { Ti }}{\text { Totals }}$ & 87.86 & 81.73 & $1,285.89$ & $4,424.16$ & $\frac{5.79}{56.79}$ \\
\hline
\end{tabular}


Table A.9 Daily midnight reservoir inflow, outflow, elevation, storage capacity, and water retention time for Lake Roosevelt in September, 1993, Data from CORPs daily summary reports.

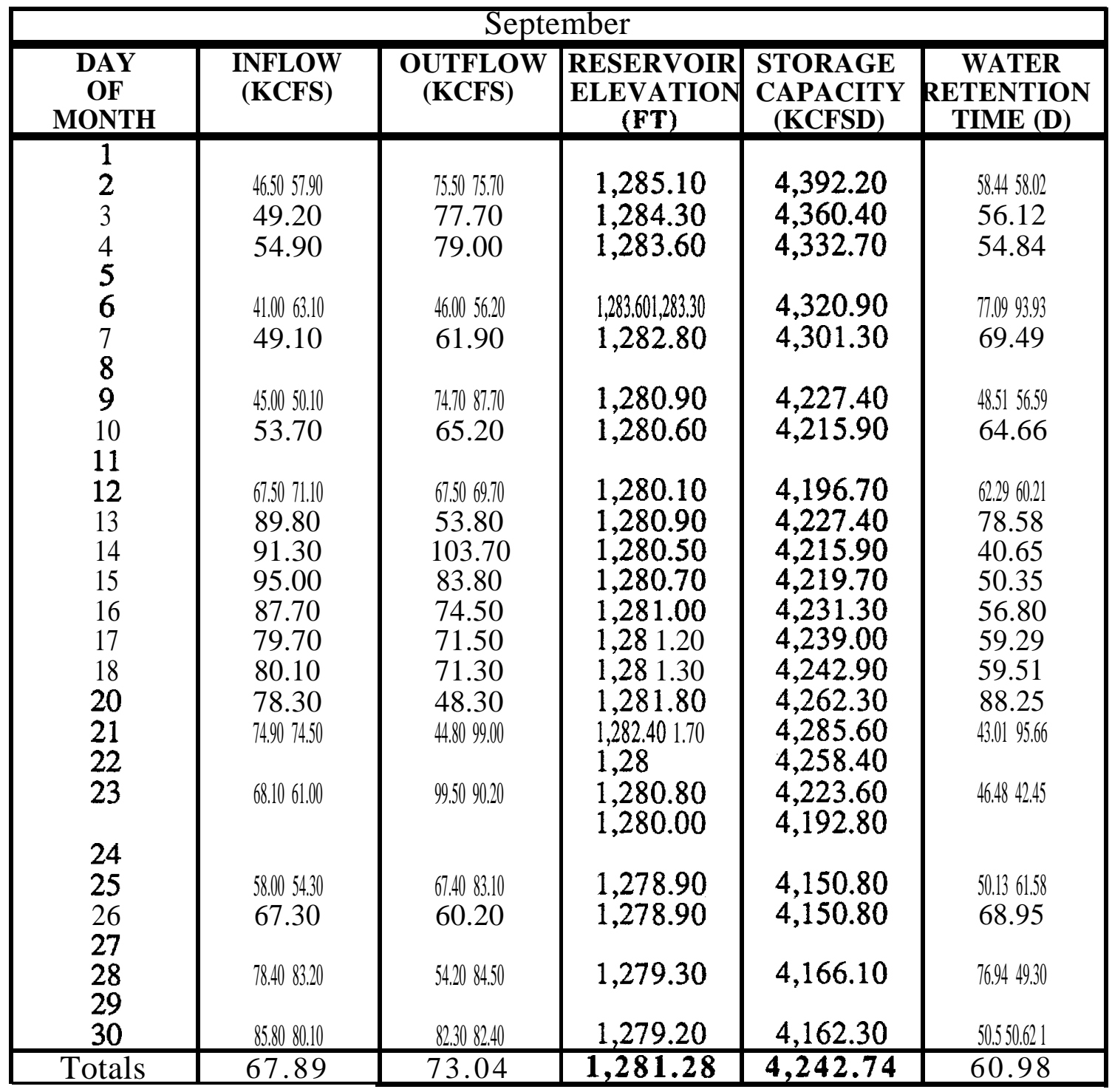


Table A.10 Daily midnight reservoir inflow, outflow, elevation, storage capacity, and water retention time for Lake Roosevelt in October, 1993. -Data from CORPs daily summary reports.

\begin{tabular}{|c|c|c|c|c|c|}
\hline \multicolumn{6}{|c|}{ October } \\
\hline $\begin{array}{c}\text { DAY } \\
\text { OF } \\
\text { MOITH }\end{array}$ & $\begin{array}{c}\text { INFLOW } \\
\text { (KCFS) }\end{array}$ & $\underset{\text { (KCFS) }}{\text { OUTFLOW }}$ & $\begin{array}{c}\text { RESERVOIR } \\
\text { ELEVATION } \\
\text { (FT) }\end{array}$ & $\begin{array}{c}\text { STORAGE } \\
\text { CAPACITY } \\
\text { (KCFSD) }\end{array}$ & \begin{tabular}{|c} 
WATER \\
RETENTION \\
TIME (D)
\end{tabular} \\
\hline 2 & 56.8058 .90 & 70.7039 .00 & $1,282.30$ & $4,281.701 .70$ & 109.7960 .56 \\
\hline 3 & 60.70 & 36.80 & $1,283.00$ & $4,309.10$ & 117.10 \\
\hline $\begin{array}{l}4 \\
5\end{array}$ & 61.7061 .00 & 72.4068 .30 & $1,282.15$ & $4,277.80$ & 59.2562 .63 \\
\hline 6 & & & & & \\
\hline 8 & 60.6057 .10 & 63.9056 .60 & $1,281,901,281.80$ & $4,262.30$ & 75.366 .761 \\
\hline 9 & 58.1059 .90 & 44.0055 .20 & $\begin{array}{l}1,281.70 \\
1,281.80\end{array}$ & $\begin{array}{l}4,258.40 \\
4,262.30\end{array}$ & 96.8777 .14 \\
\hline 10 & 60.40 & 42.30 & $1,282.00$ & $4,270.10$ & 100.95 \\
\hline 11 & 61.60 & 68.30 & $1,281.70$ & $4,258.40$ & 62.35 \\
\hline 12 & 62.40 & 72.50 & $1,281.30$ & $4,242.90$ & 58.52 \\
\hline 13 & 72.80 & 61.60 & 1281.50 & 4250.60 & 69.00 \\
\hline 14 & 71.10 & 59.90 & $1,281.70$ & $4,258.40$ & 71.09 \\
\hline 15 & 67.00 & 63.60 & $1,281.70$ & $4,258.40$ & 66.96 \\
\hline 16 & 67.80 & 41.70 & $1,282.40$ & $4,285.60$ & 102.77 \\
\hline 17 & 65.80 & 36.50 & $1,283.10$ & $4,313.10$ & 118.17 \\
\hline 18 & 67.90 & 65.90 & $1,283.20$ & $4,317.00$ & 65.51 \\
\hline 20 & 64.90 & 70.80 & $1,283.00$ & $4,309.10$ & 60.86 \\
\hline 21 & 67.7068 .00 & 74.3085 .20 & $\begin{array}{l}1,282.60 \\
1,282.40\end{array}$ & $\begin{array}{l}4,293.50 \\
4,285.60\end{array}$ & 57.6850 .39 \\
\hline 22 & 91.30 & 76.90 & $1,282.00$ & $4,270.10$ & 55.53 \\
\hline $\begin{array}{l}23 \\
24\end{array}$ & 56.6060 .40 & 47.1043 .00 & $1,282.50$ & 4.289 .50 & $90,8299.76$ \\
\hline 25 & 68.20 & 92.40 & $1,281.90$ & $4,266.20$ & 46.17 \\
\hline 26 & 63.10 & 92.20 & $1,281.10$ & $4,235.20$ & 45.93 \\
\hline 27 & 66906780 & 75508230 & 128050 & 421200 & 51275579 \\
\hline $\begin{array}{l}28 \\
29\end{array}$ & 65.80 & 77.20 & $1,280.20$ & $4,200.50$ & 54.41 \\
\hline 30 & & & & & \\
\hline 31 & 68.0075 .90 & $45.3056,00$ & $1,28501.20$ & $4,239.00$ & 75.2193 .58 \\
\hline Totals & 65.04 & 62.50 & $1,281.91$ & $4,266.25$ & 73.49 \\
\hline
\end{tabular}


Table A.11 Daily midnight reservoir inflow, outflow elevation, storage capacity, and water retention time for Lake Roosevelt in November, 1993. Data from CORPs daily summary reports.

\begin{tabular}{|c|c|c|c|c|c|}
\hline \multicolumn{6}{|c|}{ November } \\
\hline $\begin{array}{c}\text { DAY } \\
\text { OF } \\
\text { MONTH }\end{array}$ & $\begin{array}{c}\text { INFLOW } \\
\text { (KCFS) }\end{array}$ & $\begin{array}{l}\text { OUTFLOW } \\
\text { (KCFS) }\end{array}$ & $\begin{array}{c}\text { RESERVOIR } \\
\text { ELEVATION } \\
\text { (FT) }\end{array}$ & $\begin{array}{l}\text { STORAGE } \\
\text { CAPACITY } \\
\text { ( K C F S D ) }\end{array}$ & $\begin{array}{c}\text { WATER } \\
\text { RETENTION } \\
\text { TIME (D) }\end{array}$ \\
\hline 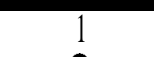 & 78.90 & 87 & $1,280.90$ & $4,227.40$ & 48.48 \\
\hline 2 & 74.90 & 86.50 & $1,280.60$ & $4,215.90$ & 48.74 \\
\hline 3 & 77.50 & 79.50 & $1,280.60$ & $4,215.90$ & 53.03 \\
\hline 4 & 74.40 & 76.30 & $1,280.50$ & $4,212.00$ & 55.20 \\
\hline 5 & 71.60 & 83.20 & $1,280.20$ & $4,200.50$ & 50.49 \\
\hline 6 & 70.70 & 64.90 & $1,280.40$ & $4,208.20$ & 64.84 \\
\hline 7 & 70.30 & 56.90 & $1,280.70$ & $4,210.70$ & 74.00 \\
\hline 8 & 72.60 & 91.90 & $1,280.20$ & $4,200.50$ & 45.71 \\
\hline 9 & 71.40 & 86.70 & $1,279.80$ & $4,185.40$ & 48.27 \\
\hline 10 & 72.90 & 84.30 & $1,279.50$ & $4,173.70$ & 49.51 \\
\hline 11 & 63.70 & 86.50 & $1,278.90$ & $4,189.00$ & 48.43 \\
\hline 12 & 72.30 & 72.30 & $1,278.90$ & $4,189.00$ & 57.94 \\
\hline 13 & 67.60 & 63.80 & $1,279.00$ & $4,154.60$ & 65.12 \\
\hline 14 & 71.00 & 63.30 & $1,279.20$ & $4,162.30$ & 65.76 \\
\hline 15 & 77.10 & 86.70 & $1,279.00$ & $4,154.60$ & 47.92 \\
\hline 16 & 72.60 & 80.20 & $1,278.75$ & $4,147.00$ & 51.71 \\
\hline 17 & 76.50 & 84.10 & $1,278.55$ & $4,139.40$ & 49.22 \\
\hline 18 & 81.10 & 71.60 & $1,278.80$ & $4,147.00$ & 57.92 \\
\hline 19 & 83.70 & 72.30 & $1,279.10$ & $4,158.50$ & 57.52 \\
\hline 20 & 80.70 & 63.50 & $1,279.55$ & $4,177.50$ & 65.79 \\
\hline 21 & 81.90 & 66.60 & $1,280.00$ & $4,129.80$ & 62.01 \\
\hline 22 & 87.30 & 112.10 & $1,279.30$ & $4,166.10$ & 37.16 \\
\hline 23 & 96.40 & 120.80 & $1,278.70$ & $4,143.20$ & 34.30 \\
\hline 24 & 86.90 & 139.80 & $1,277.30$ & $4,090.20$ & 29.26 \\
\hline 25 & 72.20 & 96.70 & $1,276.60$ & $4,063.80$ & 42.02 \\
\hline 26 & 78.40 & 108.40 & $1,275.80$ & $4,033.80$ & 37.21 \\
\hline 27 & 84.50 & 88.30 & $1,275.70$ & $4,030.10$ & 45.64 \\
\hline 28 & 77.30 & 68.00 & $1,276.00$ & $4,141.30$ & 60.90 \\
\hline 29 & 84.40 & 88.10 & $1,275.90$ & $4,037.50$ & 45.83 \\
\hline 30 & 81.50 & 94.60 & $1,275.50$ & $4,022.60$ & 42.52 \\
\hline Totals & 77.08 & 84.17 & $1,278.80$ & $4,150.92$ & 51.41 \\
\hline
\end{tabular}


Table A.12 Daily midnight reservoir inflow, outflow elevation, storage capacity, and water retention time for Lake Roosevelt in December, 1993. Data from CORPs daily summary reports.

\begin{tabular}{|c|c|c|c|c|c|}
\hline \multicolumn{6}{|c|}{ December } \\
\hline $\begin{array}{c}\text { DAY } \\
\text { OF } \\
\text { MONTH }\end{array}$ & $\begin{array}{c}\text { INFLOW } \\
\text { (KCFS) }\end{array}$ & $\begin{array}{c}\text { OUTFLOW } \\
\text { (KCFS) }\end{array}$ & $\begin{array}{c}\text { RESERVOIR } \\
\text { ELEVATION } \\
\text { (FT) }\end{array}$ & $\begin{array}{c}\text { STORAGE } \\
\text { CAPACITY } \\
\text { (KCFSD) }\end{array}$ & $\begin{array}{c}\text { WATER } \\
\text { RETENTION } \\
\text { TIME (D) }\end{array}$ \\
\hline 1 & 83.20 & 77.60 & $1,275.70$ & $4,030.10$ & 51.93 \\
\hline 2 & 86.20 & 78.70 & $1,275.90$ & $4,037.50$ & 51.30 \\
\hline 3 & 94.20 & 66.00 & $1,276.60$ & $4,063.80$ & 61.57 \\
\hline 4 & 88.70 & 58.60 & $1,277.40$ & $4,094.00$ & 69.86 \\
\hline 5 & 86.10 & 69.10 & $1,277.90$ & $4,112.90$ & 59.52 \\
\hline 6 & 82.40 & 88.10 & $1,277.70$ & $4,105.30$ & 46.60 \\
\hline 7 & 89.00 & 85.20 & $1,277.80$ & $4,109.10$ & 48.23 \\
\hline 8 & 91.00 & 85.30 & $1,278.00$ & $4,116.70$ & 48.26 \\
\hline 9 & 99.10 & 74.40 & $1,278.60$ & $4,139.40$ & 55.64 \\
\hline 10 & 85.00 & 60.30 & $1,279.30$ & $4,166.10$ & 69.09 \\
\hline 11 & 88.40 & 56.00 & $1,280.10$ & $4,196.70$ & 74.94 \\
\hline 12 & 86.10 & 61.00 & $1,280.80$ & $4,223.60$ & 69.24 \\
\hline 13 & 93.90 & 97.80 & $1,280.70$ & $4,219.70$ & 43.15 \\
\hline 14 & 80.10 & 82.10 & $1,280.60$ & $4,215.90$ & 51.35 \\
\hline 15 & 87.30 & 83.40 & $1,280.70$ & $4,219.70$ & 50.60 \\
\hline 16 & 88.30 & 99.90 & $1,280.40$ & $4,208.20$ & 42.12 \\
\hline 17 & 93.90 & 115.00 & $1,279.70$ & $4,181.40$ & 36.36 \\
\hline 18 & 74.90 & 78.70 & $1,279.80$ & $4,185.40$ & 53.18 \\
\hline 19 & 75.80 & 81.60 & $1,279.60$ & $4,177.50$ & 51.19 \\
\hline 20 & 83.30 & 102.40 & $1,279.10$ & $4,158.50$ & 40.61 \\
\hline 21 & 89.10 & 108.10 & $1,278.60$ & $4,139.40$ & 38.29 \\
\hline 22 & 87.30 & 112.00 & $1,278.00$ & $4,116.70$ & 36.76 \\
\hline 23 & 88.30 & 92.10 & $1,277.90$ & $4,112.90$ & 44.66 \\
\hline 24 & 88.60 & 63.90 & $1,278.50$ & $4,135.60$ & 64.72 \\
\hline 25 & 84.40 & 54.00 & $1,279.30$ & $4,166.10$ & 77.15 \\
\hline 26 & 79.50 & 71.90 & $1,279.50$ & $4,173.70$ & 58.05 \\
\hline 27 & 82.70 & 80.80 & $1,279.60$ & $4,177.50$ & 51.70 \\
\hline 28 & 81.70 & 79.80 & $1,279.60$ & $4,177.50$ & 52.35 \\
\hline 29 & 87.30 & 87.30 & $1,279.60$ & $4,177.50$ & 47.85 \\
\hline 30 & 90.00 & 83.30 & $1,279.80$ & $4,185.40$ & 50.24 \\
\hline 31 & 85.00 & 50.50 & $1,280.70$ & $4,219.70$ & 8355 \\
\hline Totals & 86.48 & 80.16 & 1.278 .95 & $4,153.02$ & 54.20 \\
\hline
\end{tabular}


Table A.13 Elevation-Area data points for Lake Roosevelt. Data from U.S. Bureau of Reclamation 1977.

\begin{tabular}{|c|c|c|c|}
\hline $\begin{array}{c}\text { Elevation } \\
\text { (feet) }\end{array}$ & $\begin{array}{c}\text { Area } \\
\text { (acres) }\end{array}$ & $\begin{array}{c}\text { Elevation } \\
\text { (feet) }\end{array}$ & $\begin{array}{c}\text { Area } \\
\text { (acres) }\end{array}$ \\
\hline 930.5 & 511 & 1120 & 12980 \\
\hline 940 & 819 & 1130 & 22205 \\
\hline 950 & 1219 & 1140 & 24748 \\
\hline 960 & 1700 & 1150 & 27429 \\
\hline 970 & 2260 & 1160 & 30248 \\
\hline 980 & 2900 & 1170 & 33205 \\
\hline 990 & 3520 & 1180 & 36674 \\
\hline 1000 & 4200 & 1190 & 39307 \\
\hline 1010 & 5106 & 1200 & 43059 \\
\hline 1020 & 6100 & 1210 & 46232 \\
\hline 1030 & 6815 & 1220 & 50163 \\
\hline 1040 & 7571 & 1230 & 55028 \\
\hline 1050 & 8365 & 1240 & 59811 \\
\hline 1060 & 9200 & 1250 & 63959 \\
\hline 1070 & 10688 & 1260 & 98304 \\
\hline 1080 & 12287 & 1270 & 71989 \\
\hline 1090 & 13998 & 1280 & 75949 \\
\hline 1100 & 15821 & 1290 & 82270 \\
\hline 1110 & 17755 & 1291 & 82916 \\
\hline
\end{tabular}


Table A.14 Elevation-Gross storage data points for Lake Roosevelt from Reservoir storage tables for Grand Coulee Reservoir. U.S. Bureau of Reclamation-and U.S. Geological Survey. October 1977.

\begin{tabular}{|c|c|c|c|}
\hline $\begin{array}{c}\text { Elevation } \\
\text { (feet) }\end{array}$ & $\begin{array}{c}\text { Gross Storage } \\
\text { (MAF) }\end{array}$ & $\begin{array}{c}\text { Elevation } \\
\text { (feet) }\end{array}$ & $\begin{array}{c}\text { Gross Storage } \\
\text { (MAF) }\end{array}$ \\
\hline $\begin{array}{l}1205 \\
1206 \\
1207 \\
1208 \\
1209 \\
1210 \\
1211 \\
1212 \\
1213 \\
1214 \\
1215 \\
1216 \\
1217 \\
1218 \\
1219 \\
1220 \\
1221 \\
1222 \\
1223 \\
1224 \\
1225 \\
1226 \\
1227 \\
1228 \\
1229 \\
1230 \\
1231 \\
1232 \\
1233 \\
1234 \\
1235 \\
1236 \\
1237 \\
1238 \\
1239 \\
1240 \\
1241 \\
1242 \\
1243 \\
1244 \\
1245 \\
1246 \\
1247\end{array}$ & $\begin{array}{l}3786.7 \\
3831.5 \\
3876.6 \\
3921.9 \\
3967.8 \\
4013.9 \\
4060.3 \\
4107.1 \\
4154.3 \\
4201.9 \\
4249.9 \\
4298.2 \\
4347.0 \\
4396.2 \\
4445.7 \\
4495.7 \\
4546.1 \\
4597.0 \\
4648.3 \\
4700.2 \\
4752.5 \\
4805.3 \\
4558.6 \\
4912.4 \\
4966.7 \\
5021.5 \\
5076.7 \\
5132.5 \\
5188.7 \\
5245.4 \\
5302.5 \\
5360.1 \\
5418.3 \\
5476.9 \\
5535.9 \\
5595.5 \\
5655.5 \\
5715.9 \\
5776.8 \\
5838.0 \\
5899.7 \\
5961.8 \\
6024.3\end{array}$ & $\begin{array}{l}1248 \\
1249 \\
1250 \\
1251 \\
1252 \\
1253 \\
1254 \\
1255 \\
1256 \\
1257 \\
1258 \\
1259 \\
1260 \\
1261 \\
1262 \\
1263 \\
1264 \\
1265 \\
1266 \\
1267 \\
1268 \\
1269 \\
1270 \\
1271 \\
1272 \\
1273 \\
1274 \\
1275 \\
1276 \\
1277 \\
1278 \\
1279 \\
1280 \\
1281 \\
1282 \\
1283 \\
1284 \\
1285 \\
1286 \\
1287 \\
1288 \\
1289 \\
1290\end{array}$ & $\begin{array}{l}6087.2 \\
6150.5 \\
6214.2 \\
6278.4 \\
6343.0 \\
6408.0 \\
6473.5 \\
6539.4 \\
6605.7 \\
6672.5 \\
6739.7 \\
6807.3 \\
6875.4 \\
6943.9 \\
7012.8 \\
7082.0 \\
7151.6 \\
7221.5 \\
7291.8 \\
7362.5 \\
7433.6 \\
7505.0 \\
7576.8 \\
7649.0 \\
7721.6 \\
7794.6 \\
7867.9 \\
7941.7 \\
8015.8 \\
8090.4 \\
8165.3 \\
8240.7 \\
8316.4 \\
8392.7 \\
8469.6 \\
8547.1 \\
8625.2 \\
8704.0 \\
8783.4 \\
8863.4 \\
8944.1 \\
9025.4 \\
9107.4\end{array}$ \\
\hline
\end{tabular}


APPENDIX B

ZOOPLANKTON 
No samples were colleceted in January 1993 due to inclimate weather conditions

Table B.1 Mean density $\left(\# / \mathbf{m}^{\mathbf{3}}\right.$ ) values calculated for zooplankton collected in February 1993 at four sampling locations on Lake Roosevelt, WA

\begin{tabular}{|c|c|c|c|c|}
\hline & $\begin{array}{l}\text { Gifford } \\
\text { Mean } \\
\text { Density } \\
\left(\# / \mathrm{m}^{3}\right)\end{array}$ & $\begin{array}{c}\text { Porcupine } \\
\text { Bay } \\
\text { Mean } \\
\text { Density } \\
\left(\# / \mathbf{m}^{\mathbf{3}}\right) \\
\end{array}$ & $\begin{array}{l}\text { Seven } \\
\text { Bays } \\
\text { Mean } \\
\text { Density } \\
\left(\# / \mathbf{m}^{\mathbf{3}}\right)\end{array}$ & $\begin{array}{l}\text { Spring } \\
\text { Canyon } \\
\text { Mean } \\
\text { Density } \\
\left(\mathbf{\#} / \mathbf{m}^{\mathbf{3}}\right)\end{array}$ \\
\hline $\begin{array}{l}\text { Cladocera } \\
\text { Ceriodaphnia quadranqula } \\
\text { Daphnia galeata mendotae } \\
\text { Daphnia retrocurva } \\
\text { Daphnia schødleri } \\
\text { Daphnia thorata } \\
\text { Daphnia pulex } \\
\text { Megafenestra aurita } \\
\text { Simocephalus serrulatus } \\
\text { Alona guttata } \\
\text { Alona quadrangular-is } \\
\text { Chydorus sphaericus } \\
\text { Eurycerus lamellatus } \\
\text { Pleuroxus denticulatus } \\
\text { Diaphanosoma brachyurum } \\
\text { Diaphanosoma birgei } \\
\text { Sida crystallina } \\
\text { Macrothrix laticornis } \\
\text { Streblocerus serricaudatus } \\
\text { Bosmina longirostris } \\
\text { Leptodora kindti }\end{array}$ & & 149.98 & 25.48 & 5.36 \\
\hline $\begin{array}{l}\text { Eucopepoda } \\
\text { Leptodiaptomus ashlandi } \\
\text { Skistodiaptomus } \\
\text { oregonensis }\end{array}$ & 44.25 & 610.83 & 80.45 & 130.06 \\
\hline $\begin{array}{l}\text { Epischura nevadensis } \\
\text { Diacyclops bicuspidatus } \\
\text { thomasi } \\
\text { Mesocyclop edax }\end{array}$ & 14.75 & 715.12 & 41.57 & 34.86 \\
\hline $\begin{array}{l}\text { Bryocamptus spp. } \\
\text { nauplii }\end{array}$ & 851.43 & 5393.16 & 540.66 & 1318.05 \\
\hline $\begin{array}{l}\text { TTotal Daphnia spp. } \\
\text { TTotal Cladocera } \\
\text { Trotal Copepoda } \\
\text { Trotal Nauplii } \\
\text { Trand Total }\end{array}$ & $\begin{array}{c}0.00 \\
0.00 \\
59.00 \\
851.43 \\
910.43\end{array}$ & $\begin{array}{c}149.98 \\
193.68 \\
1325.94 \\
5393.16 \\
6912.79\end{array}$ & $\begin{array}{l}25.48 \\
25.48 \\
122.02 \\
540.36 \\
687.85\end{array}$ & $\begin{array}{c}5.36 \\
5.36 \\
164.92 \\
1318.05 \\
1488.33\end{array}$ \\
\hline
\end{tabular}


Table B.2 Mean density $\left(\# / \mathbf{m}^{\mathbf{3}}\right)$ values calculated for zooplankton collected in March 1993 at four sampling locations on Lake Roosevelt, WA

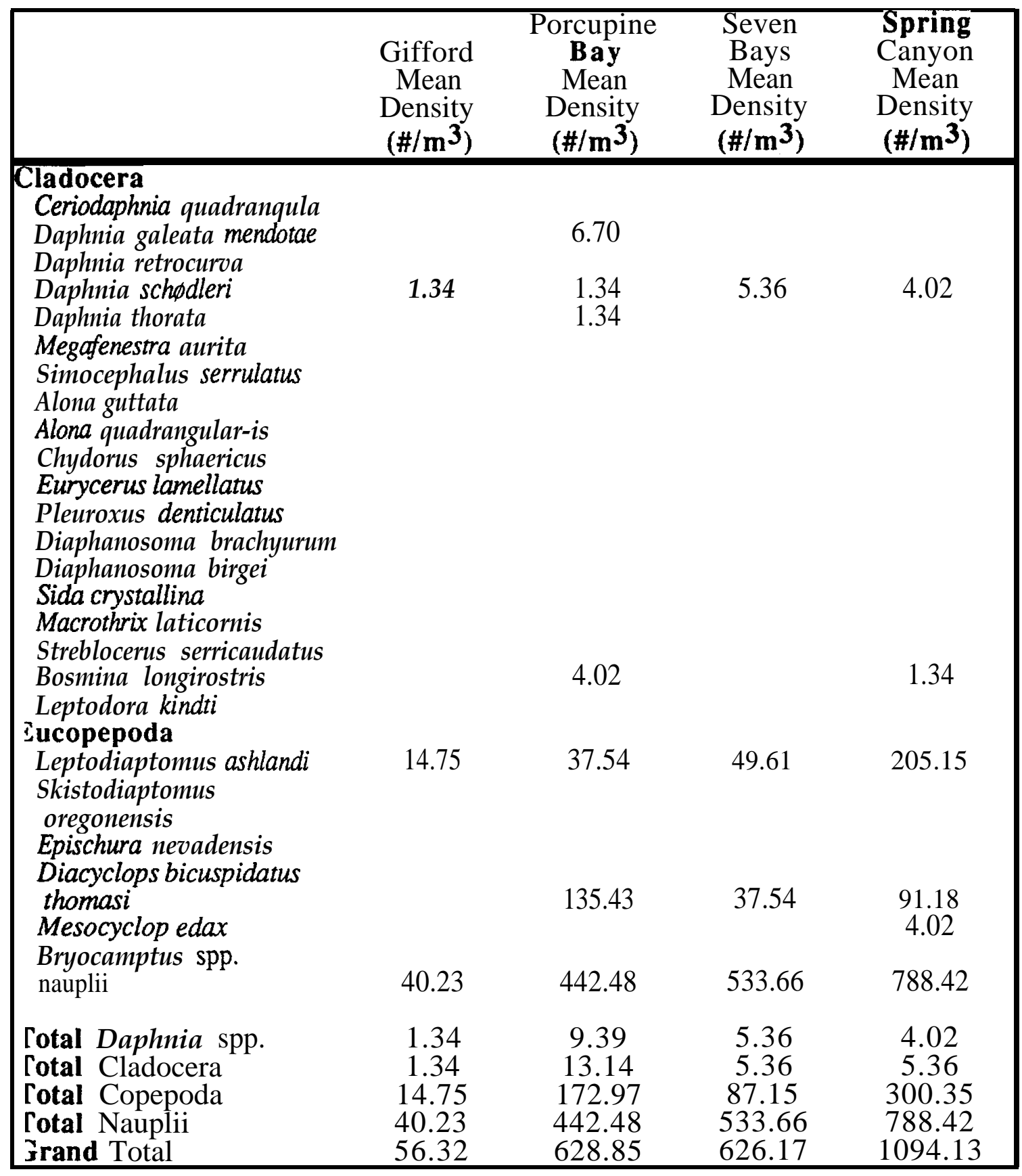


Table B.3 Mean density $\left(\# / \mathbf{m}^{\mathbf{3}}\right)$ values calculated for zooplankton collected in April 1993 at four sampling locations on Lake Roosevelt, WA

\begin{tabular}{|c|c|c|c|c|}
\hline & $\begin{array}{l}\text { Gifford } \\
\text { Mean } \\
\text { Density } \\
\left(\# / \mathbf{m}^{\mathbf{3}}\right) \\
\end{array}$ & $\begin{array}{c}\text { Porcupine } \\
\text { Bay } \\
\text { Mean } \\
\text { Density } \\
\left(\# / \mathbf{m}^{\mathbf{3}}\right)\end{array}$ & $\begin{array}{c}\text { Seven } \\
\text { Bays } \\
\text { Mean } \\
\text { Density } \\
\left(\# / \mathbf{m}^{\mathbf{3}}\right) \\
\end{array}$ & $\begin{array}{c}\text { Spring } \\
\text { Canyon } \\
\text { Mean } \\
\text { Density } \\
\left(\# / \mathbf{m}^{\mathbf{3}}\right)\end{array}$ \\
\hline \\
\hline $\begin{array}{l}\text { Ceriodaphnia quadranqula } \\
\text { Daphnia galeata mendotae }\end{array}$ & & & 6.70 & \\
\hline Daphnia schødleri & & 5.36 & 2.68 & 6.70 \\
\hline $\begin{array}{l}\text { Daphnia thorata } \\
\text { Mepafenestra aurita }\end{array}$ & & & & \\
\hline Simocephalus serrulatus & & & & \\
\hline Alona guttata & & & & \\
\hline Alona quadrangularis & & & & \\
\hline Chydorus sphaericus & & & & \\
\hline $\begin{array}{l}\text { Eurycerus lamellatus } \\
\text { Pleuroxus denticulatus }\end{array}$ & & & & \\
\hline $\begin{array}{l}\text { Diaphanosoma brachyurum } \\
\text { Diaphanosoma birgei }\end{array}$ & 2.68 & & & \\
\hline Sida crystallina & & & & \\
\hline Macrothrix laticornis & & & & \\
\hline Streblocerus serricaudatus & & & & \\
\hline $\begin{array}{l}\text { Bosmina longirostris } \\
\text { Leptodora kindti }\end{array}$ & & & & \\
\hline $\begin{array}{l}\text { Leptodora kindti } \\
\text { Iucopepoda }\end{array}$ & & & & \\
\hline $\begin{array}{l}\text { Leptodiaptomus ashlandi } \\
\text { Skistodiaptomus }\end{array}$ & 1.34 & 5.36 & 9.39 & 29.50 \\
\hline $\begin{array}{l}\text { Oregonensis } \\
\text { Epischura nevadensis }\end{array}$ & & & 1.34 & \\
\hline Diacyclops bicuspidatus & & & & \\
\hline thomasi & & 12.07 & 8.05 & 12.07 \\
\hline Mesocyclop edax & & & 1.34 & 1.34 \\
\hline $\begin{array}{l}\text { Bryocamptus spp. } \\
\text { nauplii }\end{array}$ & 4.02 & 1.34 & 61.68 & 40.23 \\
\hline | Total Daphnia spp. & 0.00 & 5.36 & 9.39 & 6.70 \\
\hline Total Cladocera & 2.68 & 5.36 & 9.39 & 6.70 \\
\hline rotal Copepoda & 1.34 & 17.43 & 20.11 & 42.91 \\
\hline Total Nauplii & 4.02 & 1.34 & 61.68 & 40.23 \\
\hline Grand Total & 8.05 & 24.14 & 91.18 & 89.84 \\
\hline
\end{tabular}


Table B.4 Mean density $\left(\# / \mathbf{m}^{\mathbf{3}}\right)$ values calculated for zooplankton collected in May 1993 at four sampling locations on Lake Roosevelt, WA

\begin{tabular}{|c|c|c|c|c|}
\hline & $\begin{array}{c}\text { Gifford } \\
\text { Mean } \\
\text { Density } \\
\left(\# / \mathbf{m}^{\mathbf{3}}\right)\end{array}$ & $\begin{array}{c}\text { Porcupine } \\
\text { Bay } \\
\text { Mean } \\
\text { Density } \\
\left(\mathbf{\#} / \mathbf{m}^{\mathbf{3}}\right)\end{array}$ & 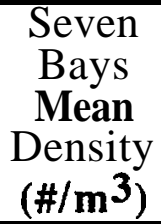 & $\begin{array}{c}\text { Spring } \\
\text { Canyon } \\
\text { Mean } \\
\text { Density } \\
\left(\# / \mathrm{m}^{3}\right)\end{array}$ \\
\hline \multirow{2}{*}{\multicolumn{5}{|c|}{$\begin{array}{l}\text { Cladocera } \\
\text { Ceriodaphnia auadranaula }\end{array}$}} \\
\hline & & & & \\
\hline Daphnia galeata mendotae & & 6.70 & 4.02 & \\
\hline Daphnia retrocurva & & 9.39 & & \\
\hline Daphnia schødleri & 24.14 & 2.68 & 603.38 & 13.41 \\
\hline Daphnia thorata & & 1.34 & & \\
\hline \multicolumn{5}{|l|}{ Megafenestra aurita } \\
\hline \multicolumn{5}{|l|}{ Simocephalus serrulatus } \\
\hline \multicolumn{5}{|l|}{ Alona guttata } \\
\hline \multicolumn{5}{|l|}{ Alona quadrangularis } \\
\hline \multicolumn{5}{|l|}{ Chydorus sphaericus } \\
\hline \multicolumn{5}{|l|}{ Eurycerus lamellatus } \\
\hline \multicolumn{5}{|l|}{ Pleuroxus denticulatus } \\
\hline \multicolumn{5}{|l|}{ Diaphanosoma brachyurum } \\
\hline \multicolumn{5}{|l|}{ Diaphanosoma birgei } \\
\hline \multicolumn{5}{|l|}{ Sida crystallina } \\
\hline \multicolumn{5}{|l|}{ Streblocerus serricaudatus } \\
\hline Bosmina longirostris & & 68.38 & 4.02 & \\
\hline \multicolumn{5}{|l|}{ Leptodora kindti } \\
\hline \multicolumn{5}{|l|}{ Ehcopepoda } \\
\hline \multirow{2}{*}{\multicolumn{5}{|c|}{ Skistodiaptomus }} \\
\hline & & & & \\
\hline Epischura nevadensis & 1.34 & & 16.09 & \\
\hline \multicolumn{5}{|l|}{ Diacyclops bicuspidatus } \\
\hline thomasi & 16.09 & 41.57 & 174.31 & 107.27 \\
\hline Mesocyclop edax & & 63.02 & 4.02 & \\
\hline $\begin{array}{l}\text { Bryocamptus spp. } \\
\text { nauplii }\end{array}$ & 4.02 & 59.00 & 79.11 & 63.02 \\
\hline Total Daphnia spp. & 24.14 & 20.11 & 607.40 & 13.41 \\
\hline otal Cladocera & 24.14 & 880.50 & 611.42 & 13.41 \\
\hline Total Copepoda & 17.43 & 104.59 & 305.71 & 162.24 \\
\hline otal Nauplii & 4.02 & 59.00 & 79.11 & 63.02 \\
\hline Irrand Total & 45.59 & 252.08 & 996.25 & 238.67 \\
\hline
\end{tabular}


Table B.5 Mean density $\left(\# / \mathbf{m}^{3}\right)$ values calculated for zooplankton collected in June 1993 at four sampling locations on Lake Roosevelt, WA

\begin{tabular}{|c|c|c|c|c|}
\hline & $\begin{array}{l}\text { Gifford } \\
\text { Mean } \\
\text { Density } \\
\left(\# / \mathbf{m}^{\mathbf{3}}\right)\end{array}$ & $\begin{array}{c}\text { Porcupine } \\
\text { Bay } \\
\text { Mean } \\
\text { Density } \\
\left(\# / \mathbf{m}^{\mathbf{3}}\right) \\
\end{array}$ & $\begin{array}{l}\text { Seven } \\
\text { Bays } \\
\text { Mean } \\
\text { Density } \\
\left(\# / \mathbf{m}^{\mathbf{3}}\right)\end{array}$ & $\begin{array}{l}\text { Spring } \\
\text { Canyon } \\
\text { Mean } \\
\text { Density } \\
\left(\# / \mathbf{m}^{\mathbf{3}}\right)\end{array}$ \\
\hline $\begin{array}{l}\text { Tadocera } \\
\text { Ceriodaphnia quadranqula } \\
\text { Daphnia galeata mendotae } \\
\text { Daphnia retrocurva } \\
\text { Daphnia schodleri } \\
\text { Daphnia thorata } \\
\text { Daphnia poulicaria } \\
\text { Daphnia thorata } \\
\text { Megafenestra aurita } \\
\text { Simocephalus serrulatus } \\
\text { Alona guttata } \\
\text { Alona quadrangularis } \\
\text { Chydorus sphaericus } \\
\text { Eurycerus lamellatus } \\
\text { Pleuroxus denticulatus } \\
\text { Diaphanosoma brachyurum } \\
\text { Diaphanosoma birgei } \\
\text { Sida crystallina } \\
\text { Macrothrix laticornis } \\
\text { Streblocerus serricaudatus }\end{array}$ & $\begin{array}{r}2.68 \\
1.34 \\
18.77 \\
1.34\end{array}$ & $\begin{array}{c}4.02 \\
67.04 \\
24.14 \\
1.34\end{array}$ & $\begin{array}{c}10.73 \\
5.36 \\
1086.08 \\
1.34 \\
1.34\end{array}$ & $\begin{array}{c}1877.18 \\
14.90 \\
14.90\end{array}$ \\
\hline $\begin{array}{l}\text { Bosmina longirostris } \\
\text { Leptodora kindti } \\
\text { Sucopepoda }\end{array}$ & $\begin{array}{c}14.75 \\
1.34\end{array}$ & $\begin{array}{c}14.75 \\
6.70\end{array}$ & $\begin{array}{c}5.36 \\
42.91\end{array}$ & 89.39 \\
\hline $\begin{array}{l}\text { Leptodiaptomus ashlandi } \\
\text { Skistodiaptomus } \\
\text { oregonensis }\end{array}$ & 1.34 & 14.75 & 126.04 & 1772.89 \\
\hline $\begin{array}{l}\text { Epischura nevadensis } \\
\text { Diacyclops bicuspidatus }\end{array}$ & & 10.73 & 13.41 & 29.80 \\
\hline $\begin{array}{l}\text { thomasi } \\
\text { Mesocyclop edax } \\
\text { Bryocamptus spp. } \\
\text { nauplii }\end{array}$ & 6.70 & $\begin{array}{l}59.00 \\
16.09 \\
24.14\end{array}$ & $\begin{array}{l}134.08 \\
8.05 \\
32.18\end{array}$ & $\begin{array}{c}685.32 \\
74.49 \\
1102.47\end{array}$ \\
\hline $\begin{array}{l}\text { Cotal Daphnia spp. } \\
\text { Cotal Cladocera } \\
\text { Cotal Copepoda } \\
\text { Cotal Nauplii } \\
\text { hand Total }\end{array}$ & $\begin{array}{l}24.14 \\
40.23 \\
8.05 \\
1.34 \\
49.61 \\
\end{array}$ & $\begin{array}{l}96.54 \\
117.99 \\
100.56 \\
24.14 \\
242.69\end{array}$ & $\begin{array}{c}1104.85 \\
1153.12 \\
281.58 \\
32.18 \\
1466.88\end{array}$ & $\begin{array}{l}1906.98 \\
1996.36 \\
2562.50 \\
1102.47 \\
5661.33\end{array}$ \\
\hline
\end{tabular}


Table B.6 Mean density $\left(\# / \mathbf{m}^{\mathbf{3}}\right)$ values calculated for zooplankton collected in July 1993 at four sampling locations on Lake Roosevelt, WA

\begin{tabular}{|c|c|c|c|c|}
\hline & $\begin{array}{l}\text { Gifford } \\
\text { Mean } \\
\text { Density } \\
\left(\# / \mathbf{m}^{\mathbf{3}}\right)\end{array}$ & $\begin{array}{c}\text { Porcupine } \\
\text { Bay } \\
\text { Mean } \\
\text { Density } \\
\left(\# / \mathbf{m}^{\mathbf{3}}\right)\end{array}$ & $\begin{array}{c}\text { Seven } \\
\text { Bays } \\
\text { Mean } \\
\text { Density } \\
\left(\mathbf{\#} / \mathbf{m}^{\mathbf{3}}\right)\end{array}$ & $\begin{array}{c}\text { Spring } \\
\text { Canyon } \\
\text { Mean } \\
\text { Density } \\
\left(\mathbf{\#} / \mathbf{m}^{\mathbf{3}}\right)\end{array}$ \\
\hline \multicolumn{5}{|l|}{$\begin{array}{l}\text { Cladocera } \\
\text { Ceriodaphnia quadranqula }\end{array}$} \\
\hline Daphnia galeata mendotae & 13.41 & 54.97 & 52.74 & 1.34 \\
\hline Daphnia retrocurva & 8.05 & 557.79 & 31.14 & 4.02 \\
\hline Daphnia schødleri & 105.93 & 225.26 & 2869.10 & 489.41 \\
\hline Daphnia thorata & 2.68 & 32.18 & 4.02 & \\
\hline Meggfenestra aurita & & & & \\
\hline Simocephalus serrulatus & & & & \\
\hline Alona guttata & & & & \\
\hline Alona quadrangular-is & & & & \\
\hline Chydorus sphaericus & & & & \\
\hline Eurycerus lamellatus & & & & \\
\hline Pleuroxus denticulatus & & & & \\
\hline Diaphanosoma brachyurun & & & & \\
\hline Diaphanosoma birgei & & & & \\
\hline Sida crystallina & & & 31.14 & \\
\hline Macrothrix laticornis & & & & \\
\hline Streblocerus serricaudatus & & & & \\
\hline Bosmina longirostris & 2.68 & & & \\
\hline Leptodora kindti & & 6.70 & & \\
\hline hcopepoda & & & & \\
\hline $\begin{array}{l}\text { Leptodiaptomus ashlandi } \\
\text { Skistodiaptomus }\end{array}$ & 6.70 & 124.70 & 52.74 & 277.55 \\
\hline $\begin{array}{l}\text { Oregonensis } \\
\text { Epischura nevadensis }\end{array}$ & & & & 13.41 \\
\hline Diacyclops bicuspidatus & & & & \\
\hline thomasi & 4.02 & 100.56 & 120.38 & 12.07 \\
\hline Mesocyclop edax & & 100.56 & 1.34 & 2.68 \\
\hline $\begin{array}{l}\text { Bryocamptus spp. } \\
\text { nauplii }\end{array}$ & 18.77 & 41.57 & 62.27 & 4.02 \\
\hline Cotal Daphnia spp. & 130.06 & 870.21 & 2957.00 & 494.77 \\
\hline Total Cladocera & 132.74 & 876.91 & 2988.14 & 494.77 \\
\hline Cotal Copepoda & 10.73 & 335.21 & 174.46 & 305.71 \\
\hline Total Nauplii & 18.77 & 41.57 & 62.27 & 4.02 \\
\hline Jrand Total & 162.24 & 1253.69 & 3224.87 & 804.51 \\
\hline
\end{tabular}


Table B.7 Mean density $\left(\# / \mathbf{m}^{\mathbf{3}}\right)$ values calculated for zooplankton collected in August 1993 at four sampling locations on Lake Roosevelt, WA

\begin{tabular}{|c|c|c|c|c|}
\hline & $\begin{array}{l}\text { Gifford } \\
\text { Mean } \\
\text { Density } \\
\left(\# / \mathbf{m}^{\mathbf{3}}\right)\end{array}$ & $\begin{array}{l}\text { Porcupine } \\
\text { Bay } \\
\text { Mean } \\
\text { Density } \\
\left(\# / \mathbf{m}^{\mathbf{3}}\right) \\
\end{array}$ & $\begin{array}{l}\text { Seven } \\
\text { Bays } \\
\text { Mean } \\
\text { Density } \\
\left(\# / \mathbf{m}^{\mathbf{3}}\right)\end{array}$ & $\begin{array}{l}\text { Spring } \\
\text { Canyon } \\
\text { Mean } \\
\text { Density } \\
\left(\# / \mathbf{m}^{\mathbf{3}}\right)\end{array}$ \\
\hline \multicolumn{5}{|l|}{ Cladocera } \\
\hline $\begin{array}{l}\text { Ceriodaphnia quadranqula } \\
\text { Daphnia galeata mendotae } \\
\text { Daphnia retrocurva }\end{array}$ & 18.77 & $\begin{array}{c}6.70 \\
64.36\end{array}$ & 104.29 & 17.43 \\
\hline $\begin{array}{l}\text { Daphnia schødleri } \\
\text { Daphnia thorata } \\
\text { Megafenestra aurita }\end{array}$ & 324.48 & $\begin{array}{c}159.56 \\
1.34\end{array}$ & $\begin{array}{l}8015.26 \\
74.49\end{array}$ & $\begin{array}{c}1328.77 \\
12.07\end{array}$ \\
\hline $\begin{array}{l}\text { Simocephalus serrulatus } \\
\text { Alona quttata }\end{array}$ & & & & \\
\hline Alona quadrangular-is & & & & \\
\hline $\begin{array}{l}\text { Chydorus sphaericus } \\
\text { Eurycerus lamellatus }\end{array}$ & & & & \\
\hline $\begin{array}{l}\text { Eurycerus lamellatus } \\
\text { Pleuroxus denticulatus }\end{array}$ & & & & \\
\hline Diaphanosoma brachyurum & & & & \\
\hline Diaphanosoma birgei & & & & \\
\hline $\begin{array}{l}\text { Sida crystallina } \\
\text { Macrothrix laticornis }\end{array}$ & & & & \\
\hline $\begin{array}{l}\text { Streblocerus serricaudatus } \\
\text { Bosmina longirostris }\end{array}$ & & & & \\
\hline Leptodora kindti & & 1.34 & 74.49 & \\
\hline \multicolumn{5}{|l|}{ Eucopepoda } \\
\hline $\begin{array}{l}\text { Leptodiaptomus ashlandi } \\
\text { Skistodiaptomus } \\
\text { oregonensis }\end{array}$ & 8.05 & 45.59 & 193.68 & 172.97 \\
\hline Epischura nevadensis & 2.68 & & 59.59 & 33.52 \\
\hline $\begin{array}{l}\text { Diacyclops bicuspidatus } \\
\text { thomasi } \\
\text { Mesocyclop edax }\end{array}$ & 2.68 & $\begin{array}{l}32.18 \\
26.82\end{array}$ & 134.08 & 29.50 \\
\hline $\begin{array}{l}\text { Bryocamptus spp. } \\
\text { nauplii }\end{array}$ & & 77.77 & 864.10 & 13.41 \\
\hline $\begin{array}{l}\text { Total Daphnia spp. } \\
\text { Total Cladocera } \\
\text { Total Copepoda } \\
\text { Total Nauplii } \\
\text { Grand Total }\end{array}$ & $\begin{array}{c}343.26 \\
343.26 \\
13.41 \\
0.00 \\
356.66 \\
\end{array}$ & $\begin{array}{l}231.97 \\
233.31 \\
104.59 \\
77.77 \\
415.66\end{array}$ & $\begin{array}{r}8194.03 \\
8268.53 \\
387.35 \\
864.10 \\
9519.98 \\
\end{array}$ & $\begin{array}{c}1358.27 \\
1358.27 \\
256.10 \\
13.41 \\
1627.78 \\
\end{array}$ \\
\hline
\end{tabular}


Table B.8 Mean density $\left(\# / \mathbf{m}^{\mathbf{3}}\right)$ values calculated for zooplankton collected in September 1993 at four sampling locations on Lake Roosevelt, WA

\begin{tabular}{|c|c|c|c|c|}
\hline & $\begin{array}{l}\text { Gifford } \\
\text { Mean } \\
\text { Density } \\
\left(\# / \mathbf{m}^{\mathbf{3}}\right)\end{array}$ & $\begin{array}{c}\text { Porcupine } \\
\text { Bay } \\
\text { Mean } \\
\text { Density } \\
\left(\# / \mathbf{m}^{\mathbf{3}}\right)\end{array}$ & $\begin{array}{c}\text { Seven } \\
\text { Bays } \\
\text { Mean } \\
\text { Density } \\
\left(\# / \mathbf{m}^{\mathbf{3}}\right)\end{array}$ & $\begin{array}{c}\text { Spring } \\
\text { Canyon } \\
\text { Mean } \\
\text { Density } \\
\left(\# / \mathbf{m}^{\mathbf{3}}\right)\end{array}$ \\
\hline \multicolumn{5}{|l|}{ Cladocera } \\
\hline Ceriodaphnia quadranqula & & & NO & \\
\hline Daphnia galeata mendotae & 3933.14 & 22.79 & DATA & 1.90 \\
\hline Daphnia retrocurva & 148.98 & 1.34 & COLLECTED & \\
\hline Daphnia schødleri & 2502.91 & 1346.21 & & 1267.10 \\
\hline Daphnia thorata & 178.78 & 12.07 & & 1.34 \\
\hline \multicolumn{5}{|l|}{$\begin{array}{l}\text { Megafenestra aurita } \\
\text { Simocephalus serrulatus }\end{array}$} \\
\hline \multicolumn{5}{|l|}{ Alona guttata } \\
\hline \multicolumn{5}{|l|}{ Alona quadrangular-is } \\
\hline \multirow{2}{*}{\multicolumn{5}{|c|}{$\begin{array}{l}\text { Chydorus sphaericus } \\
\text { Eurycerus lamellatus }\end{array}$}} \\
\hline \multirow{2}{*}{\multicolumn{5}{|c|}{ Pleuroxus denticulatus }} \\
\hline & & & & \\
\hline \multicolumn{5}{|l|}{$\begin{array}{l}\text { Diaphanosoma brachyurum } \\
\text { Diaphanosoma birgei }\end{array}$} \\
\hline \multicolumn{5}{|l|}{ Sida crystallina } \\
\hline \multicolumn{5}{|l|}{$\begin{array}{l}\text { Macrothrix laticornis } \\
\text { Streblocerus serricaudatus }\end{array}$} \\
\hline \multicolumn{5}{|l|}{ Bosmina longirostris } \\
\hline Leptodora kindti & 29.80 & 6.70 & & \\
\hline \multicolumn{5}{|l|}{ ESucopepoda } \\
\hline $\begin{array}{l}\text { Leptodiaptomus ashlandi } \\
\text { Skistodiaptomus }\end{array}$ & & 30.84 & & 190.40 \\
\hline \multirow{2}{*}{\multicolumn{5}{|c|}{$\begin{array}{l}\text { Epischura nevadensis } \\
\text { Diacyclops bicuspidatus }\end{array}$}} \\
\hline \multirow{2}{*}{\multicolumn{5}{|c|}{$\begin{array}{l}\text { Diacyclops bicuspidatus } \\
\text { thomasi }\end{array}$}} \\
\hline & 89.39 & 105.93 & & $\begin{array}{l}13.41 \\
20.11\end{array}$ \\
\hline \multirow{2}{*}{$\begin{array}{l}\text { Bryocamptus spp. } \\
\text { nauplii }\end{array}$} & 2080 & $\begin{array}{l}18.77 \\
2414\end{array}$ & & 039 \\
\hline & & & & \\
\hline Cotal Daphnia spp. & 6763.80 & 1382.41 & & 1296.59 \\
\hline Cotal Cládocera & 6793.60 & 1395.82 & & 1297.94 \\
\hline Cotal Copepoda & 89.39 & 155.54 & & 266.83 \\
\hline Cotal Nauplii & 29.80 & 24.14 & & 9.39 \\
\hline Irand Total & 6912.79 & 1575.49 & & 1574.15 \\
\hline
\end{tabular}


Table B.9 Mean density $\left(\# / \mathbf{m}^{\mathbf{3}}\right)$ values calculated for zooplankton collected in October 1993 at four sampling locations on Lake Roosevelt, WA

\begin{tabular}{|c|c|c|c|c|}
\hline & $\begin{array}{c}\text { Gifford } \\
\text { Mean } \\
\text { Density } \\
\left(\# / \mathbf{m}^{\mathbf{3}}\right)\end{array}$ & $\begin{array}{c}\text { Porcupine } \\
\text { Bay } \\
\text { Mean } \\
\text { Density } \\
\left(\# / \mathbf{m}^{\mathbf{3}}\right)\end{array}$ & $\begin{array}{c}\text { Seven } \\
\text { Bays } \\
\text { Mean } \\
\text { Density } \\
\left(\# / \mathbf{m}^{3}\right)\end{array}$ & $\begin{array}{c}\text { Spring } \\
\text { Canyon } \\
\text { Mean } \\
\text { Density } \\
\left(\# / \mathbf{m}^{\mathbf{3}}\right)\end{array}$ \\
\hline \multicolumn{5}{|l|}{$\begin{array}{l}\text { Cladocera } \\
\text { Ceriodaphnia quadranqula }\end{array}$} \\
\hline Daphnia galeata mendotae & 230.62 & & 10.73 & 10.73 \\
\hline Daphnia retrocurva & 1.34 & & 8.05 & 2.68 \\
\hline Daphnia schødleri & 158.22 & 244.03 & 970.77 & 4.02 \\
\hline $\begin{array}{l}\text { Daphnia thorata } \\
\text { Megafenestra aurita }\end{array}$ & 97.88 & & 193.08 & 1.34 \\
\hline Simocephalus serrulatus & & & & \\
\hline $\begin{array}{l}\text { Alona guttata } \\
\text { Alona quadrangularis }\end{array}$ & & & & \\
\hline Chydorus sphaericus & & & & \\
\hline $\begin{array}{l}\text { Eurycerus lamellatus } \\
\text { Pleuroxus denticulatus }\end{array}$ & & & & \\
\hline Pleuroxus denticulatus & & & & \\
\hline $\begin{array}{l}\text { Diaphanosoma brachyurum } \\
\text { Diapharwsoma birgei }\end{array}$ & 2.68 & & & 2.68 \\
\hline $\begin{array}{l}\text { Sida crystallina } \\
\text { Macrothrix laticornis }\end{array}$ & 1.34 & & 2.68 & \\
\hline Streblocerus serricaudatus & & & & \\
\hline $\begin{array}{l}\text { Bosmina longirostris } \\
\text { Leptodora kindti }\end{array}$ & & & & \\
\hline \multirow{2}{*}{\multicolumn{5}{|c|}{ ESucopepoda }} \\
\hline & & & & \\
\hline $\begin{array}{l}\text { Leptodiaptomus ashlandi } \\
\text { Skistodiaptomus } \\
\text { oregonensis }\end{array}$ & 10.73 & 24.14 & 284.26 & 14.75 \\
\hline Epischura nevadensis & & & & \\
\hline \multicolumn{5}{|l|}{ Diacyclops bicuspidatus } \\
\hline thomasi & 9.39 & 13.41 & 13.41 & 5.36 \\
\hline Mesocyclop edax & 5.36 & 2.68 & 40.23 & 1.34 \\
\hline $\begin{array}{l}\text { Bryocamptus spp. } \\
\text { nauplii }\end{array}$ & & 8.05 & & 6.70 \\
\hline Ootal Daphnia spp. & 488.07 & 244.03 & 1182.62 & 18.77 \\
\hline otal Cladocera & 492.09 & 244.03 & 1185.30 & 22.79 \\
\hline otal Copepoda & 25.48 & 40.23 & 337.89 & 21.45 \\
\hline otal Nauplii & 0.00 & 8.05 & 0.00 & 6.70 \\
\hline Irand Total & 517.57 & 292.30 & 1523.20 & 50.95 \\
\hline
\end{tabular}


Table B.10 Mean density $\left(\# / \mathbf{m}^{\mathbf{3}}\right)$ values calculated for zoopiankton collected in November 1993 at 'four sampling locations' on Lake Roosevelt, WA

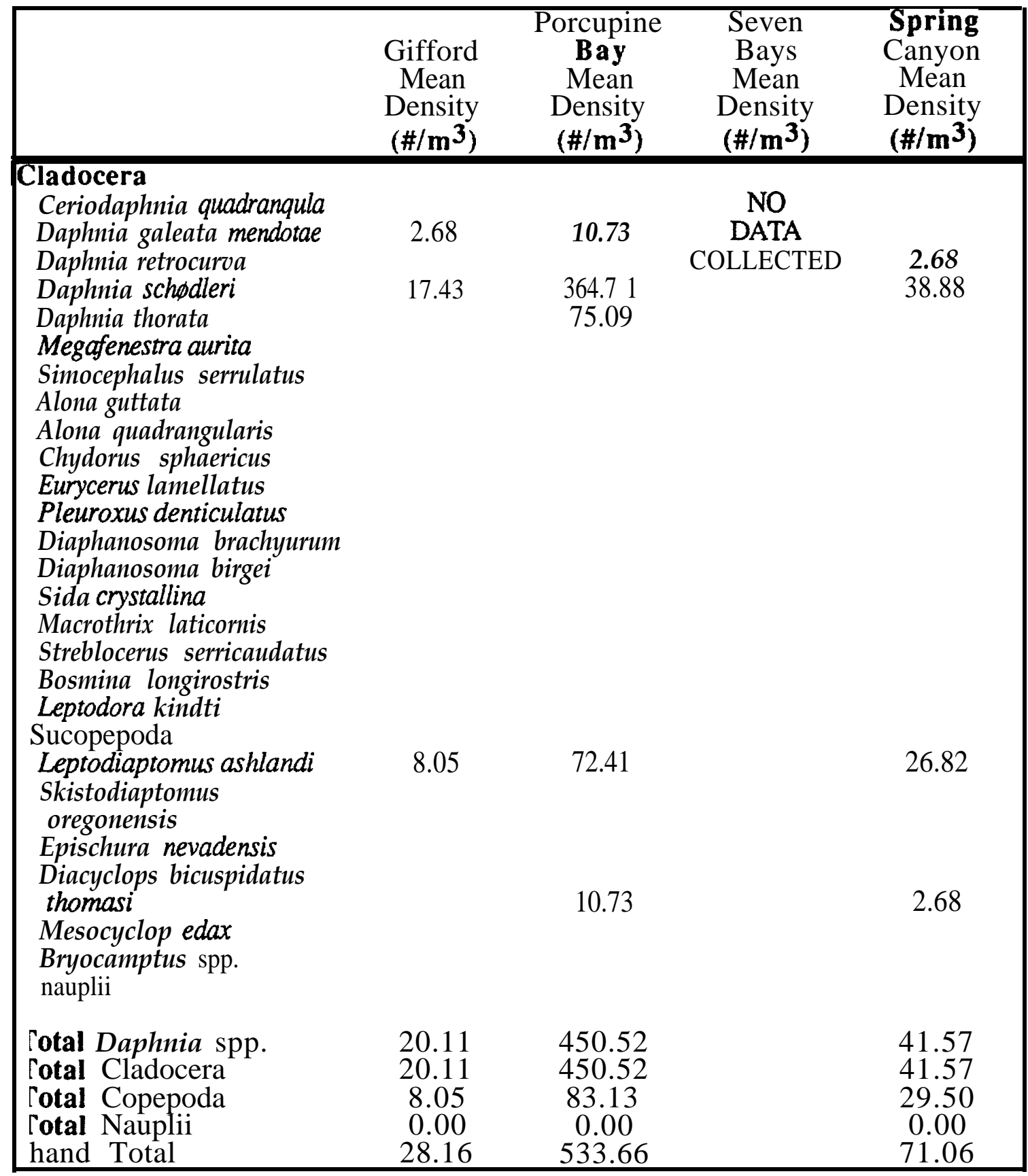


Table B.11 Mean density $\left(\# / \mathbf{m}^{\mathbf{3}}\right)$ values calculated for zooplankton collected in December 1993 at $^{\star}$ four sampling locations on Lake Roosevelt, WA

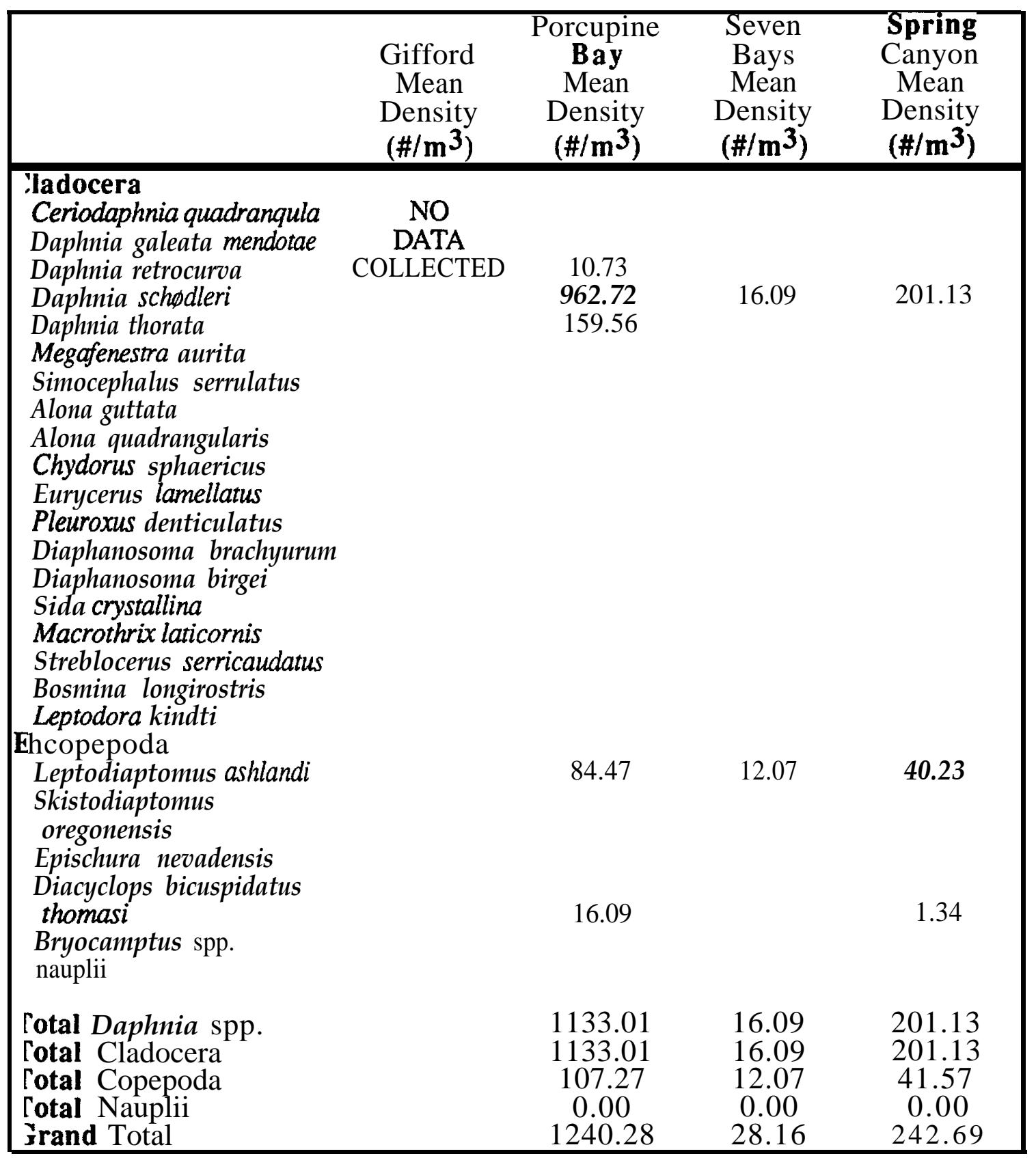


No samples were colleceted in January 1993 due to inclimate weather conditions

Table B.12 Size ranges $(\mathrm{mm})$, mean lengths $(\mathrm{mm})$ and biomass calculations $\left(\mu \mathrm{g} / \mathrm{m}^{3}\right)$ for zooplankton collected at four sampling locations in February 1993 on Lake Roosevelt, WA

\begin{tabular}{|c|c|c|c|}
\hline & $\begin{array}{c}\text { Size } \\
\text { range } \\
(\mathbf{m m})\end{array}$ & $\begin{array}{r}\text { Mean } \\
\text { length } \\
(\mathbf{m m})\end{array}$ & $\begin{array}{l}\text { Biomass } \\
\left(\boldsymbol{\mu} \mathbf{g} / \mathbf{m}^{\mathbf{3}}\right)\end{array}$ \\
\hline $\begin{array}{l}\text { Location } 2 \\
\text { Daphnia galeata } \\
\text { mendotae } \\
\text { Daphnia retrocurva } \\
\text { Daphnia schodleri } \\
\text { Daphnia thorata } \\
\text { Leptodora kindti }\end{array}$ & & & \\
\hline $\begin{array}{l}\text { Total Biomass } \\
\text { ocation } 4 \\
\text { Daphnia galeata } \\
\text { memiotae } \\
\text { Daphnia retrocwea } \\
\text { Daphnia schødleri } \\
\text { Daphnia thorata } \\
\text { Leptodora kindti } \\
\end{array}$ & $0.78-1.22$ & 0.93 & 1197.93 \\
\hline $\begin{array}{l}\text { Total Biomass } \\
\text { ocation } 6 \\
\text { Daphnia galeata } \\
\text { mendotae } \\
\text { Daphnia retrocwva } \\
\text { Daphnia schødleri } \\
\text { Daphnia thorata } \\
\text { Leptodora kindti }\end{array}$ & $0.76-1.62$ & 1.07 & 1197.93 \\
\hline $\begin{array}{l}\text { Total Biomass } \\
\text { ocation } 9 \\
\text { Daphnia galeata } \\
\text { mendotae } \\
\text { Daphnia retrocurva } \\
\text { Daphnia schodleri } \\
\text { Daphnia thorata } \\
\text { Leptodora kindti } \\
\text { Total Biomass }\end{array}$ & $0.64-1.28$ & 0.90 & 318.74 \\
\hline
\end{tabular}


Table B.13 Size ranges $(\mathrm{mm})$, mean lengths. $(\mathrm{mm})$ and biomass calculations $\left(\mu \mathrm{g} / \mathrm{m}^{3}\right)$ for zooplankton collected at four sampling locations in March 1993 on Lake Roosevelt, WA

\begin{tabular}{|c|c|c|c|}
\hline & $\begin{array}{l}\text { Size } \\
\text { range } \\
(\mathbf{m m})\end{array}$ & $\begin{array}{r}\text { Mean } \\
\text { length } \\
(\mathbf{m m})\end{array}$ & $\begin{array}{l}\text { Biomass } \\
\left(\boldsymbol{\mu} \mathbf{g} / \mathbf{m}^{3}\right)\end{array}$ \\
\hline $\begin{array}{l}\text {-ocation } 2 \\
\text { Daphnia galeata } \\
\text { mendotae } \\
\text { Daphnia retrocurva } \\
\text { Daphnia schødleri } \\
\text { Daphnia thorata } \\
\text { Leptodora kindti }\end{array}$ & & 1.40 & 3.68 \\
\hline $\begin{array}{l}\text { Total Biomass } \\
\text {-ocation } 4 \\
\text { Daphnia galeata } \\
\text { mendotae }\end{array}$ & $0.98-1.32$ & 1.18 & 46.73 \\
\hline $\begin{array}{l}\text { Daphnia schødleri } \\
\text { Daphnia thorata } \\
\text { Leptodora kindti }\end{array}$ & & $\begin{array}{l}0.82 \\
1.20\end{array}$ & $\begin{array}{c}7.22 \\
29.84\end{array}$ \\
\hline $\begin{array}{l}\text { Total Biomass } \\
\text { socation } 6 \\
\text { Daphnia galeata } \\
\text { mendotae } \\
\text { Daphnia retrocurva } \\
\text { Daphnia schodleri } \\
\text { Daphnia thorata } \\
\text { Leptodora kindti } \\
\end{array}$ & $1.18-1.50$ & 1.36 & 83.79 \\
\hline $\begin{array}{l}\text { Total Biomass } \\
\text {-ocation } 9 \\
\text { Daphnia galeata } \\
\text { mendotae } \\
\text { Daphnia retrocurva }\end{array}$ & & & 138.68 \\
\hline $\begin{array}{l}\text { Daphnia schødleri } \\
\text { Daphnia thorata } \\
\text { Leptodora kindti } \\
\text { Total Biomass }\end{array}$ & $0.70-0.80$ & 0.77 & 17.59 \\
\hline
\end{tabular}


Table B.14 Size ranges $(\mathrm{mm})$, mean lengths $(\mathrm{mm})$ and biomass calculations $\left(\mu \mathrm{g} / \mathrm{m}^{3}\right)$ for zooplankton collected at four sampling locations in April 1993 on Lake Roosevelt, WA

\begin{tabular}{|c|c|c|c|}
\hline & $\begin{array}{c}\text { Size } \\
\text { range } \\
(\mathbf{m m})\end{array}$ & $\begin{array}{r}\text { Mean } \\
\text { length } \\
\text { (mm) }\end{array}$ & $\begin{array}{l}\text { Biomass } \\
\left(\boldsymbol{\mu} \mathbf{g} / \mathbf{m}^{\mathbf{3}}\right)\end{array}$ \\
\hline $\begin{array}{l}\text { Ocation } 2 \\
\text { Daphnia galeata } \\
\text { mendotae } \\
\text { Daphnia retrocwva } \\
\text { Daphnia schødleri } \\
\text { Daphnia thorata } \\
\text { Leptodora kindti }\end{array}$ & & & \\
\hline $\begin{array}{l}\text { Total Biomass } \\
\text { socation } 4 \\
\text { Daphnia galeata } \\
\text { mendotae } \\
\text { Daphnia retrocurva } \\
\text { Daphnia schddleri } \\
\text { Daphnia thorata } \\
\text { Leptodora kindti } \\
\end{array}$ & $0.78-1.04$ & 0.90 & 38.57 \\
\hline $\begin{array}{l}\text { Total Biomass } \\
\text { ocation } 6 \\
\text { Daphnia galeata } \\
\text { mendotae } \\
\text { Daphnia retrocurva } \\
\text { Daphnia schødleri } \\
\text { Daphnia thorata } \\
\text { Leptodora kindti }\end{array}$ & $\begin{array}{l}0.70-0.84 \\
0.66-0.84\end{array}$ & $\begin{array}{l}0.78 \\
0.75\end{array}$ & $\begin{array}{l}15.85 \\
10.96\end{array}$ \\
\hline $\begin{array}{l}\text { Total Biomass } \\
\text { Location } 9 \\
\text { Daphnia galeata } \\
\text { mendotae } \\
\text { Daphnia retrocurva } \\
\text { Daphnia schødleri } \\
\text { Daphnia thorata } \\
\text { Leptodora kindti } \\
\text { Total Biomass }\end{array}$ & $0.76-1.40$ & 1.15 & 26.81 \\
\hline
\end{tabular}


Table B.15 Size ranges $(\mathrm{mm})$, mean lengths $(\mathrm{mm})$ and biomass calculations $\left(\mu \mathrm{g} / \mathbf{m}^{\mathbf{3}}\right)$ for zooplankton collected at four sampling locations in May $\mathbf{1 9 9 3}$ on Lake Roosevelt, WA

\begin{tabular}{|c|c|c|c|}
\hline & $\begin{array}{c}\text { Size } \\
\text { range } \\
(\mathbf{m m})\end{array}$ & $\begin{array}{l}\text { Mean } \\
\text { length } \\
\text { (mm) }\end{array}$ & $\begin{array}{l}\text { Biomass } \\
\left(\mu \mathrm{g} / \mathrm{m}^{3}\right)\end{array}$ \\
\hline $\begin{array}{l}\text { Docation } 2 \\
\text { Daphnia galeata } \\
\text { menabtae } \\
\text { Daphnia retrocurva } \\
\text { Daphnia schpdleri } \\
\text { Daphnia thorata } \\
\text { Leptodora kindti }\end{array}$ & $0.52-1.14$ & 0.73 & 92.06 \\
\hline $\begin{array}{l}\text { Total Biomass } \\
\text { Location } 4 \\
\text { Daphnia galeata } \\
\text { menabtae } \\
\text { Daphnia retrocurva } \\
\text { Daphnia schodleri } \\
\text { Daphnia thorata } \\
\text { Leptodora kindti }\end{array}$ & $\begin{array}{c}0.86-1.44 \\
0.84-1.22 \\
0.88-1.02 \\
1.22\end{array}$ & $\begin{array}{l}1.06 \\
1.04 \\
0.95 \\
1.22\end{array}$ & $\begin{array}{l}36.93 \\
44.08 \\
22.80 \\
31.12\end{array}$ \\
\hline $\begin{array}{l}\text { Total Biomass } \\
\text { Location } 6 \\
\text { Daphnia galeata } \\
\text { menabtae } \\
\text { Daphnia retrocurva } \\
\text { Daphnia schødleri } \\
\text { Daphnia thorata } \\
\text { Leptodora kindti } \\
\end{array}$ & $\begin{array}{l}0.80-1.00 \\
0.42-1.90\end{array}$ & $\begin{array}{l}0.88 \\
1.19\end{array}$ & $\begin{array}{c}13.12 \\
10119.33\end{array}$ \\
\hline $\begin{array}{l}\text { Total Biomass } \\
\text { Location } 9 \\
\text { Daphnia galeata } \\
\text { menabtae } \\
\text { Daphnia retrocurva } \\
\text { Daphnia schddleri } \\
\text { Daphnia thorata } \\
\text { Leptodora kindti } \\
\text { Total Biomass } \\
\end{array}$ & $0.84-1.42$ & 1.24 & 10132.45 \\
\hline
\end{tabular}


Table B.16 Size ranges $(\mathrm{mm})$, mean lengths $(\mathrm{mm})$ and biomass calculations $\left(\mu \mathrm{g} / \mathrm{m}^{3}\right)$ for zooplankton collected at four sampling locations in June 1993 on Lake Roosevelt, WA

\begin{tabular}{|c|c|c|c|}
\hline & $\begin{array}{c}\text { Size } \\
\text { range } \\
(\mathbf{m m})\end{array}$ & $\begin{array}{l}\text { Mean } \\
\text { length } \\
\text { (mm) }\end{array}$ & $\begin{array}{l}\text { Biomass } \\
\left(\mu \mathrm{g} / \mathrm{m}^{3}\right)\end{array}$ \\
\hline \multicolumn{4}{|l|}{-ocation 2} \\
\hline Daphniagaleata & & & \\
\hline mendotae & $0.80-1.10$ & 0.95 & 10.64 \\
\hline Daphnia retrocwova & 0.98 & 0.98 & 5.27 \\
\hline Daphnia schødleri & $0.70-1.96$ & 1.06 & 227.10 \\
\hline Daphnia thorata & & 0.90 & 14.37 \\
\hline Leptodora kindti & 11.00 & 11.00 & 355.33 \\
\hline \multirow{2}{*}{\multicolumn{4}{|c|}{$\begin{array}{l}\text { Total Biomass } \\
\text { ocation } 4\end{array}$}} \\
\hline & & & \\
\hline $\begin{array}{l}\text { Daphnia galeata } \\
\text { mendotae }\end{array}$ & $0.96-1.22$ & 1.05 & 20.79 \\
\hline Daphnia retrocurva & $0.60-1.82$ & 1.11 & 385.89 \\
\hline Daphnia schodleri & $0.80-1.62$ & 1.06 & 286.57 \\
\hline Daphnia thorata & 1.16 & 1.16 & 27.38 \\
\hline Leptodora kindti & $3.00-8.50$ & 4.70 & 183.48 \\
\hline \multirow{2}{*}{\multicolumn{4}{|c|}{ Total Biomass }} \\
\hline & \multicolumn{3}{|c|}{$\begin{array}{l}\text {-ocation } 6 \\
\text { Danhnia galeata }\end{array}$} \\
\hline $\begin{array}{l}\text { Daphnia galeata } \\
\text { mendotae }\end{array}$ & $0.76-1.24$ & 1.03 & 52.39 \\
\hline Daphnia pulicaria & 1.78 & 1.78 & 79.85 \\
\hline Daphnia retrocwea & $0.78-0.88$ & 0.82 & 12.06 \\
\hline $\begin{array}{l}\text { Daphnia schodleri } \\
\text { Daphnia thorata }\end{array}$ & $0.60-2.08$ & 1.18 & 17858.97 \\
\hline Leptodora kindti & $2.50-11.00$ & 4.89 & 109.21 \\
\hline \multicolumn{4}{|l|}{$\begin{array}{l}\text { Total Biomass } \\
\text { ocation } 9 \\
\text { Daphnia galeata } \\
\text { mendotae }\end{array}$} \\
\hline $\begin{array}{l}\text { Daphnia pulicaria } \\
\text { Daphnia retrocurva }\end{array}$ & 1.16 & 1.16 & 235.44 \\
\hline Daphnia schødleri & $0.88-2.28$ & 1.62 & 83369.02 \\
\hline Daphnia thorata & 1.24 & 1.24 & 360.59 \\
\hline $\begin{array}{l}\text { Leptodora kindti } \\
\text { Total Biomass }\end{array}$ & $3.50-13.50$ & 9.50 & 16025.84 \\
\hline
\end{tabular}


Table B.17 Size ranges $(\mathrm{mm})$, mean lengths $(\mathrm{mm})$ and biomass calculations $\left(\mu \mathrm{g} / \mathrm{m}^{\mathbf{3}}\right)$ for zooplankton collected at four sampling locations in July 1993 on Lake Roosevelt, WA

\begin{tabular}{|c|c|c|c|}
\hline & $\begin{array}{c}\text { Size } \\
\text { range } \\
(\mathbf{m m})\end{array}$ & $\begin{array}{r}\text { Mean } \\
\text { length } \\
(\mathbf{m m})\end{array}$ & $\begin{array}{l}\text { Biomass } \\
\left(\boldsymbol{\mu} \mathbf{g} / \mathbf{m}^{\mathbf{3}}\right)\end{array}$ \\
\hline $\begin{array}{l}\text { Docation } 2 \\
\text { Daphnia galeata } \\
\text { mendotae } \\
\text { Daphnia retrocurva } \\
\text { Daphnia schødleri } \\
\text { Danhnia thorata } \\
\text { Leptodora kindti }\end{array}$ & $\begin{array}{c}0.88-0.98 \\
0.76-1.40 \\
0.46-1.54 \\
1.22-1.60\end{array}$ & $\begin{array}{l}0.93 \\
1.14 \\
0.94 \\
1.41\end{array}$ & $\begin{array}{c}50.41 \\
50.33 \\
863.55 \\
89.89\end{array}$ \\
\hline $\begin{array}{l}\text { Total Biomass' } \\
\text { socation } 4 \\
\text { Daphnia galeata } \\
\text { mendotae } \\
\text { Daphnia retrocurva } \\
\text { Daphnia schødleri } \\
\text { Daphnia thorata } \\
\text { Leptodora kindti }\end{array}$ & $\begin{array}{c}0.82-2.22 \\
0.60-2.00 \\
0.50-2.08 \\
0.78-2.0 \\
5.00-12.00 \\
\end{array}$ & $\begin{array}{l}1.60 \\
1.37 \\
1.32 \\
1.28 \\
7.00 \\
\end{array}$ & $\begin{array}{c}826.17 \\
6277.01 \\
5442.03 \\
925.64 \\
531.49 \\
\end{array}$ \\
\hline $\begin{array}{l}\text { Totation } 6 \\
\text { Daphnia galeata } \\
\text { mendotae } \\
\text { Daphnia retrocwova } \\
\text { Daphnia schødleri } \\
\text { Daphnia thorata } \\
\text { Leptodora kindti }\end{array}$ & $\begin{array}{l}0.66-1.42 \\
0.84-1.64 \\
0.60-2.00 \\
1.40-1.60\end{array}$ & $\begin{array}{l}1.11 \\
1.31 \\
1.02 \\
1.50\end{array}$ & $\begin{array}{c}309.46 \\
301.16 \\
30290.20 \\
157.77\end{array}$ \\
\hline $\begin{array}{l}\text { Total Biomass } \\
\text { Location } 9 \\
\text { Daphnia galeata } \\
\text { mendotae } \\
\text { Daphnia retrocurva } \\
\text { Daphnia schødleri } \\
\text { Daphnia thorata } \\
\text { Leptodora kindti } \\
\text { Total Biomass }\end{array}$ & $\begin{array}{c}1.12 \\
0.98-1.30 \\
0.56-1.90\end{array}$ & $\begin{array}{l}1.12 \\
1.14 \\
1.11\end{array}$ & $\begin{array}{c}8.11 \\
25.37 \\
6661.66\end{array}$ \\
\hline
\end{tabular}


Table B.18 Size ranges $(\mathrm{mm})$, mean lengths $(\mathrm{mm})$ and biomass calculations $\left(\mu \mathrm{g} / \mathrm{m}^{3}\right)$ for zooplankton collected at four sampling locations in August 1993 on Lake Roosevelt, WA

\begin{tabular}{|c|c|c|c|}
\hline & $\begin{array}{c}\text { Size } \\
\text { range } \\
(\mathbf{m m})\end{array}$ & $\begin{array}{r}\text { Mean } \\
\text { length } \\
\text { (mm) }\end{array}$ & $\begin{array}{l}\text { Biomass } \\
\left(\mu \mathrm{g} / \mathbf{m}^{\mathbf{3}}\right)\end{array}$ \\
\hline \\
\hline $\begin{array}{l}\text { Daphnia galeata } \\
\text { mendotae }\end{array}$ & $0.60-0.82$ & 0.65 & 35.91 \\
\hline Daphnia retrocurva & & & \\
\hline Daphnia schødleri & $0.44-1.08$ & 0.79 & 1534.18 \\
\hline $\begin{array}{l}\text { Daphnia thorata } \\
\text { Leptodora kindti }\end{array}$ & & & \\
\hline \multirow{2}{*}{\multicolumn{4}{|c|}{$\begin{array}{l}\text { Total Biomass } \\
\text { _ocation } 4\end{array}$}} \\
\hline & & & \\
\hline \multicolumn{4}{|l|}{ Daphnia galeata } \\
\hline Daphnia retrocurva & $0.76-1.84$ & 1.29 & 604394 \\
\hline Daphnia schødleri & $0.64-1.24$ & 0.92 & 1226.74 \\
\hline Daphnia thorata & 1.00 & 1.00 & 18.78 \\
\hline Leptodora kindti & 3.00 & 3.00 & 11.07 \\
\hline \multicolumn{4}{|l|}{ Total Biomass } \\
\hline \multicolumn{4}{|l|}{ socation 6} \\
\hline Daphnia galeata & & & \\
\hline \multicolumn{4}{|l|}{$\begin{array}{l}\text { mendotae } \\
\text { Daphnia retrocurva }\end{array}$} \\
\hline \multicolumn{4}{|l|}{ Daphnia schodleri } \\
\hline Daphnia thorata & $0.82-2.40$ & 1.64 & 3681.45 \\
\hline Leptodora kindti & $5.00-7.00$ & 5.67 & 3361.19 \\
\hline \multicolumn{4}{|l|}{ Total Biomass } \\
\hline \multirow{2}{*}{\multicolumn{4}{|c|}{ _ocation 9}} \\
\hline & & & \\
\hline \multicolumn{4}{|l|}{$\begin{array}{l}\text { mendotae } \\
\text { Daphnia retrocurva }\end{array}$} \\
\hline Daphnia schødleri & $0.68-2.20$ & 1.24 & 25521.95 \\
\hline Daphnia thorata & $1.08-2.20$ & 1.48 & 460.46 \\
\hline Leptodora kindti & & & \\
\hline Total Biomass & & & 26065.83 \\
\hline
\end{tabular}


Table B.19 Size ranges $(\mathrm{mm})$, mean lengths $(\mathrm{mm})$ and biomass calculations $\left(\mu \mathrm{g} / \mathrm{m}^{3}\right)$ for zooplankton collected at four sampling locations in September 1993 on Lake Roosevelt, WA

\begin{tabular}{|c|c|c|c|}
\hline & $\begin{array}{l}\text { Size } \\
\text { range } \\
(\mathbf{m m}) \\
\end{array}$ & $\begin{array}{l}\text { Mean } \\
\text { length } \\
\text { (mm) }\end{array}$ & $\begin{array}{l}\text { Biomass } \\
\left(\mu \mathbf{g} / \mathbf{m}^{\mathbf{3}}\right)\end{array}$ \\
\hline \multicolumn{4}{|l|}{$\begin{array}{l}\text { ocation } 2 \\
\text { Daphnia galeata }\end{array}$} \\
\hline mendotae & $0.64-1.60$ & 0.95 & 17217.73 \\
\hline Daphnia retrocurva & $1.40-1.80$ & 1.64 & 2911.07 \\
\hline Daphnia schødleri & $0.82-1.60$ & 1.07 & 30879.47 \\
\hline Daphnia thorata & $0.78-1.80$ & 1.13 & 5359.95 \\
\hline Leptodora kindti & 5.00 & 5.00 & 962.67 \\
\hline \multicolumn{4}{|l|}{$\begin{array}{l}\text { Total Biomass } \\
\text { ocation } 4\end{array}$} \\
\hline \multicolumn{4}{|l|}{ Daphnia galeata } \\
\hline Daphnia retrocwova & $\begin{array}{l}0.00-1.00 \\
1.70\end{array}$ & 1.70 & 29.52 \\
\hline Daphnia schødleri & $0.60-2.00$ & 1.01 & 14636.51 \\
\hline Daphnia thorata & $1.30-1.84$ & 1.63 & 581.16 \\
\hline Leptodora kindti & $3.50-8.00$ & 5.10 & 228.19 \\
\hline \multicolumn{4}{|l|}{$\begin{array}{l}\text { Total Biomass } \\
\text { ocation } 6\end{array}$} \\
\hline \multicolumn{4}{|l|}{ Daphnia galeata } \\
\hline \multirow{2}{*}{\multicolumn{4}{|c|}{$\begin{array}{l}\text { mendotae } \\
\text { Daphnia retrocurva }\end{array}$}} \\
\hline & & & \\
\hline \multirow{2}{*}{\multicolumn{4}{|c|}{$\begin{array}{l}\text { Dapnia tnorata } \\
\text { Leptodora kindti }\end{array}$}} \\
\hline & & & \\
\hline \multicolumn{4}{|l|}{ Total Biomass } \\
\hline \multirow{2}{*}{\multicolumn{4}{|c|}{$\begin{array}{l}\text { Docation } 9 \\
\text { Daphnia galeata }\end{array}$}} \\
\hline & & & \\
\hline \multirow{2}{*}{\multicolumn{4}{|c|}{$\begin{array}{l}\text { mendotae } \\
\text { Daphnia retrocurva }\end{array}$}} \\
\hline & & & \\
\hline \multirow{3}{*}{$\begin{array}{l}\text { Daphnia schodleri } \\
\text { Daphnia thorata } \\
\text { Leptodora kindti }\end{array}$} & $0.80-2.60$ & 1.40 & 35825.47 \\
\hline & 1.20 & 1.20 & 22.27 \\
\hline & & & 36077.36 \\
\hline
\end{tabular}


Table B.20 Size ranges $(\mathrm{mm})$, mean lengths $(\mathrm{mm})$ and biomass calculations $\left(\mu \mathrm{g} / \mathbf{m}^{3}\right)$ for zooplankton collected at four sampling locations in October-1993 on Lake Roosevelt, WA

\begin{tabular}{|c|c|c|c|}
\hline & $\begin{array}{l}\text { Size } \\
\text { range } \\
(\mathbf{m m})\end{array}$ & $\begin{array}{l}\text { Mean } \\
\text { length } \\
(\mathbf{m m})\end{array}$ & $\begin{array}{l}\text { Biomass } \\
\left(\mu \mathbf{g} / \mathbf{m}^{\mathbf{3}}\right)\end{array}$ \\
\hline \multicolumn{4}{|l|}{$\begin{array}{l}\text { Location } 2 \\
\text { Daphnia galeata }\end{array}$} \\
\hline mendotae & $0.88-1.82$ & 1.40 & 2468.15 \\
\hline Daphnia retrocurva & 1.46 & 1.46 & 18.34 \\
\hline Daphnia schodleri & $0.98-1.80$ & 1.42 & 4669.39 \\
\hline $\begin{array}{l}\text { Daphnia thorata } \\
\text { Leptodora kindti }\end{array}$ & $0.88-1.80$ & & 3087.81 \\
\hline $\begin{array}{l}\text { Total Biomass } \\
\text { Location } 4\end{array}$ & & & 10243.69 \\
\hline \multirow{2}{*}{\multicolumn{4}{|c|}{$\begin{array}{l}\text { Location } 4 \\
\text { Daphnia galeata } \\
\text { mendotae }\end{array}$}} \\
\hline & & & \\
\hline \multicolumn{4}{|l|}{ Daphnia retrocurva } \\
\hline Daphnia schødleri & $0.78-2.44$ & 1.72 & 13146.34 \\
\hline $\begin{array}{l}\text { Daphnia thorata } \\
\text { Leptodora kindti }\end{array}$ & & & \\
\hline \multicolumn{4}{|l|}{ Total Biomass } \\
\hline \multirow{2}{*}{\multicolumn{4}{|c|}{$\begin{array}{l}\text { Location } 6 \\
\text { Daphnia galeata }\end{array}$}} \\
\hline & & & \\
\hline mendotae & $0.72-1.40$ & 1.10 & 61.28 \\
\hline Daphnia retrocurva & $1.04-1.68$ & 1.33 & 82.93 \\
\hline Daphnia schødleri & $0.74-2.36$ & 1.47 & 31763.40 \\
\hline $\begin{array}{l}\text { Daphnia thorata } \\
\text { Ientodora kindti }\end{array}$ & $0.74-2.56$ & 1.64 & 9564.57 \\
\hline \begin{tabular}{|l} 
Total Biomass \\
\end{tabular} & & & 41472.18 \\
\hline \multirow{2}{*}{\multicolumn{4}{|c|}{$\begin{array}{l}\text { Location } 9 \\
\text { Dambin ogleata }\end{array}$}} \\
\hline & & & \\
\hline mendotae & $1.26-2.10$ & 1.63 & 169.00 \\
\hline Daphnia retrocurva & $1.00-1.18$ & 1.09 & 14.70 \\
\hline Daphnia schødleri & $0.74-1.12$ & 0.89 & 96.31 \\
\hline Daphnia thorata & 2.24 & 2.24 & 145.64 \\
\hline Total Biomass & & & 425.64 \\
\hline
\end{tabular}


Table B.21 Size ranges $(\mathrm{mm})$, mean lengths $(\mathrm{mm})$ and biomass calculations $\left(\mu \mathrm{g} / \mathrm{m}^{3}\right)$ for zooplankton collected at four sampling locations in November 1993 on Lake Roosevelt, WA

\begin{tabular}{|c|c|c|c|}
\hline & $\begin{array}{l}\text { Size } \\
\text { range } \\
(\mathbf{m m})\end{array}$ & $\begin{array}{l}\text { Mean } \\
\text { length } \\
(\mathbf{m m})\end{array}$ & $\begin{array}{l}\text { Biomass } \\
\left(\boldsymbol{\mu} \mathbf{g} / \mathbf{m}^{\mathbf{3}}\right)\end{array}$ \\
\hline \multicolumn{4}{|l|}{ Location 2} \\
\hline $\begin{array}{l}\text { Daphnia galeata } \\
\text { mendotae } \\
\text { Daphnia retrocurva }\end{array}$ & $0.94-1.60$ & 1.27 & 22.37 \\
\hline $\begin{array}{l}\text { Daphnia schodleri } \\
\text { Daphnia thorata } \\
\text { Leptodora kindti }\end{array}$ & $0.86-2.20$ & 1.42 & 513.82 \\
\hline Total Biomass & & & 536.19 \\
\hline \multicolumn{4}{|l|}{ Location 4} \\
\hline $\begin{array}{l}\text { Daphnia galeata } \\
\text { mendotae } \\
\text { Daphnia retrocurva }\end{array}$ & $1.34-1.82$ & 1.60 & 161.78 \\
\hline Daphnia schødleri & $0.96-2.36$ & 1.60 & 15466.18 \\
\hline $\begin{array}{l}\text { Daphnia thorata } \\
\text { Leptodora kindti }\end{array}$ & $0.98-2.48$ & 1.59 & 3411.73 \\
\hline $\begin{array}{l}\text { Total Biomass } \\
\text { Location } 6 \\
\text { Daphnia galeata } \\
\text { mendotae } \\
\text { Daphnia retrocurva } \\
\text { Daphnia schødleri } \\
\text { Daphnia thorata } \\
\text { Leptodora kindti }\end{array}$ & & & 19039.69 \\
\hline \multicolumn{3}{|l|}{$\begin{array}{l}\text { Daphniagaleata } \\
\text { mendotae }\end{array}$} & \\
\hline Daphnia retrocurva & $1.24-1.66$ & 1.45 & 35.90 \\
\hline $\begin{array}{l}\text { Daphnia schodleri } \\
\text { Daphnia thorata } \\
\text { Leptodora kindti }\end{array}$ & $0.82-2.24$ & 1.40 & 1107.26 \\
\hline Total Biomass & & & 1143.16 \\
\hline
\end{tabular}


Table B.22 Size ranges $(\mathrm{mm})$, mean lengths $(\mathrm{mm})$ and biomass calculations $\left(\mu \mathrm{g} / \mathrm{m}^{\mathbf{3}}\right)$ for zooplankton collected at four sampling locations in December 1993 on Lake Roosevelt, WA

\begin{tabular}{|c|c|c|c|}
\hline & $\begin{array}{c}\text { Size } \\
\text { range } \\
(\mathbf{m m})\end{array}$ & $\begin{array}{r}\text { Mean } \\
\text { length } \\
\text { (mm) }\end{array}$ & $\begin{array}{l}\text { Biomass } \\
\left(\mu \mathbf{g} / \mathbf{m}^{\mathbf{3}}\right)\end{array}$ \\
\hline $\begin{array}{l}\text {-ocation } 2 \\
\text { Daphnia galeata } \\
\text { mendotae } \\
\text { Daphnia retrocurva } \\
\text { Daphnia schødleri } \\
\text { Daphnia thorata } \\
\text { Leptodora kindti }\end{array}$ & $0.78-2.42$ & 1.28 & 414.17 \\
\hline $\begin{array}{l}\text { Total Biomass } \\
\text { ocation } 4 \\
\text { Daphnia galeata } \\
\text { mendotae } \\
\text { Daphnia retrocurva } \\
\text { Daphnia schddleri } \\
\text { Daphnia thorata } \\
\text { Leptodora kindti }\end{array}$ & $\begin{array}{l}0.78-1.44 \\
0.72-2.20 \\
0.78-2.42\end{array}$ & $\begin{array}{l}1.09 \\
1.26 \\
1.28\end{array}$ & $\begin{array}{c}58.42 \\
19705.80 \\
4206.56\end{array}$ \\
\hline $\begin{array}{l}\text { Total Biomass } \\
\text { ocation } 6 \\
\text { Daphnia galeata } \\
\text { mendotae } \\
\text { Daphnia retrocurva } \\
\text { Daphnia schodleri } \\
\text { Daphnia thorata } \\
\text { Leptodora kindti } \\
\end{array}$ & $0.74-1.40$ & 0.98 & 23970.78 \\
\hline $\begin{array}{l}\text { Total Biomass } \\
\text { ocation 9 } \\
\text { Daphnia galeata } \\
\text { mendotae } \\
\text { Daphnia retrocurva } \\
\text { Daphnia schødleri } \\
\text { Daphnia thorata } \\
\text { Leptodora kindti } \\
\text { Total Biomass }\end{array}$ & $0.76-2.04$ & 1.37 & 149.16 \\
\hline
\end{tabular}




\section{APPENDIX C \\ BENTHIC MACROINVERTEBRATES}


Table C.1 Number of benthic macroinvertebrate samples collected each month at each location on Lake Roosevelt in 1993.

\begin{tabular}{|c|c|c|c|c|c|}
\hline Month & $\begin{array}{c}\text { Res. } \\
\text { Elevation }\end{array}$ & $\begin{array}{c}\text { Res. } \\
\text { Location }\end{array}$ & $\begin{array}{c}\text { Area } \\
\text { Number }\end{array}$ & $\begin{array}{l}\text { Number } \\
\text { of } \\
\text { Samples }\end{array}$ & $\begin{array}{c}\text { Mean } \\
\text { Sample } \\
\text { Depth (m) }\end{array}$ \\
\hline \multirow[t]{6}{*}{ May } & \multirow[t]{6}{*}{1285} & 2 & $\begin{array}{l}2 \\
3\end{array}$ & $\begin{array}{l}2 \\
0\end{array}$ & $\begin{array}{l}24 \\
15\end{array}$ \\
\hline & & \multirow[t]{2}{*}{4} & $\begin{array}{l}1 \\
2\end{array}$ & $\begin{array}{l}2 \\
2\end{array}$ & 24 \\
\hline & & & $\begin{array}{l}3 \\
1\end{array}$ & $\begin{array}{l}0 \\
2\end{array}$ & \\
\hline & & \multirow[t]{2}{*}{6} & 2 & 2 & $\begin{array}{l}24 \\
15\end{array}$ \\
\hline & & & 3 & 0 & \\
\hline & & 9 & $\begin{array}{l}2 \\
3\end{array}$ & $\begin{array}{l}2 \\
0\end{array}$ & $\begin{array}{l}24 \\
15\end{array}$ \\
\hline \multirow[t]{9}{*}{ July } & \multirow[t]{9}{*}{1286} & \multirow[t]{3}{*}{2} & $-\frac{1}{2}$ & $-\frac{2}{2}$ & 24 \\
\hline & & & 3 & 2 & $\begin{array}{l}15 \\
6\end{array}$ \\
\hline & & & 1 & 2 & 24 \\
\hline & & \multirow{2}{*}{4} & 2 & 2 & 15 \\
\hline & & & 3 & 2 & 6 \\
\hline & & \multirow[t]{2}{*}{6} & 1 & 2 & 24 \\
\hline & & & 3 & 2 & 156 \\
\hline & & \multirow[t]{2}{*}{9} & 2 & 2 & 24 \\
\hline & & & 3 & 2 & $\begin{array}{c}13 \\
6\end{array}$ \\
\hline
\end{tabular}


Table C.1 Continued.

\begin{tabular}{|c|c|c|c|c|c|}
\hline Month & $\begin{array}{c}\text { Res. } \\
\text { Elevation }\end{array}$ & $\begin{array}{c}\text { Res. } \\
\text { Location }\end{array}$ & $\begin{array}{c}\text { Area } \\
\text { Number }\end{array}$ & $\begin{array}{c}\text { Number } \\
\text { of } \\
\text { Samples }\end{array}$ & $\begin{array}{c}\text { Mean } \\
\text { Sample } \\
\text { Depth (m) }\end{array}$ \\
\hline \multirow[t]{4}{*}{ August } & \multirow[t]{4}{*}{1286} & 2 & $\begin{array}{l}1 \\
2 \\
3\end{array}$ & $\begin{array}{l}3 \\
3 \\
3\end{array}$ & $\begin{array}{c}24 \\
15 \\
6\end{array}$ \\
\hline & & 4 & $\begin{array}{l}1 \\
2 \\
3\end{array}$ & $\begin{array}{l}2 \\
2 \\
2\end{array}$ & $\begin{array}{c}24 \\
15 \\
6\end{array}$ \\
\hline & & 6 & $\begin{array}{l}1 \\
2 \\
3\end{array}$ & $\begin{array}{l}2 \\
2 \\
2\end{array}$ & $\begin{array}{c}24 \\
15 \\
6\end{array}$ \\
\hline & & 9 & $\begin{array}{l}1 \\
2 \\
3 \\
\end{array}$ & $\begin{array}{l}3 \\
3 \\
3 \\
\end{array}$ & $\begin{array}{c}24 \\
15 \\
6 \\
\end{array}$ \\
\hline \multirow[t]{4}{*}{ September } & \multirow[t]{4}{*}{1281} & 2 & $\begin{array}{l}1 \\
2 \\
3\end{array}$ & $\begin{array}{l}0 \\
1 \\
2\end{array}$ & $\begin{array}{c}- \\
15 \\
6\end{array}$ \\
\hline & & 4 & $\begin{array}{l}1 \\
2 \\
3\end{array}$ & $\begin{array}{l}2 \\
2 \\
1\end{array}$ & $\begin{array}{c}24 \\
15 \\
6\end{array}$ \\
\hline & & 6 & $\begin{array}{l}1 \\
2 \\
3\end{array}$ & $\begin{array}{l}1 \\
1 \\
1\end{array}$ & $\begin{array}{c}24 \\
15 \\
6\end{array}$ \\
\hline & & 9 & $\begin{array}{l}1 \\
2 \\
3\end{array}$ & $\begin{array}{l}1 \\
1 \\
1\end{array}$ & $\begin{array}{c}24 \\
15 \\
6\end{array}$ \\
\hline
\end{tabular}


Table C.2 Number of acres within each benthic macroinvertebrate sampling area and calculations.

Samping Areas and Descriptions:

Area 111210 at full pool

Area 2 From 1211 to 1240 at full pool

Area3 From 1290 to 1241

\begin{tabular}{|c|c|c|c|}
\hline $\begin{array}{c}\text { Benthic } \\
\text { Sampling } \\
\text { Area }\end{array}$ & $\begin{array}{c}\text { Elev. } \\
\text { used for } \\
\text { calculations }\end{array}$ & $\begin{array}{c}\text { Acres } \\
\text { at } \\
\text { elevation }\end{array}$ & $\begin{array}{c}\text { \# of Acres } \\
\text { in Sampling } \\
\text { Area }\end{array}$ \\
\hline 1 & $\begin{array}{c}1210 \\
930.5\end{array}$ & $\begin{array}{c}46,232 \\
511\end{array}$ & 45,721 \\
\hline 2 & 1240 & 59811 & 13,579 \\
\hline 3 & 1210 & 46232 & 22,459 \\
\hline
\end{tabular}

Acres converted to $\mathbf{m}^{2}$.

\begin{tabular}{|c|c|c|}
\hline Sampling Area & $\begin{array}{c}\text { Acres/Area } \\
(\times 4046.8564)\end{array}$ & $\mathbf{m}^{\mathbf{2}}$ Area \\
\hline 1 & 45,721 & $\mathbf{1 8 5 , 0 2 6 , 3 2 1}$ \\
\hline 2 & 13,579 & $\mathbf{5 4 , 9 5 2 , 2 6 3}$ \\
\hline 3 & 22,459 & $90,888,348$ \\
\hline
\end{tabular}


Table C.3 Orders and families of benthic macroinvertebrates found in the substrate of Lake Roosevelt.

\begin{tabular}{|c|c|c|}
\hline Order & $\begin{array}{l}\text { Amphipoda } \\
\text { Family: }\end{array}$ & $\begin{array}{l}\text { (scuds) } \\
\text { Gammerus }\end{array}$ \\
\hline Order & $\begin{array}{l}\text { Basommatop } \\
\text { Family }\end{array}$ & $\begin{array}{l}\text { Dhora (snails) } \\
\text { Lynmaeidae } \\
\text { Planoribidae } \\
\text { Physidae }\end{array}$ \\
\hline Order & $\begin{array}{l}\text { Diptera (mic } \\
\text { Family }\end{array}$ & $\begin{array}{l}\text { dges) } \\
\text { Chironomidae }\end{array}$ \\
\hline Order & $\begin{array}{l}\text { Hydrachnella } \\
\text { Family }\end{array}$ & $\begin{array}{c}\text { ae (aquatic spiders) } \\
\text { Hydracarina }\end{array}$ \\
\hline Order & $\begin{array}{l}\text { Oligocheata } \\
\text { Family }\end{array}$ & $\begin{array}{l}\text { (worms) } \\
\text { Lumbriculidae }\end{array}$ \\
\hline Order & $\begin{array}{l}\text { Pelecypoda } \\
\text { Family }\end{array}$ & $\begin{array}{l}\text { (clams) } \\
\text { Sphaeridae }\end{array}$ \\
\hline Order & $\begin{array}{l}\text { Trichoptera } \\
\text { Family }\end{array}$ & $\begin{array}{l}\text { (caddisflies) } \\
\text { Leptoceridae } \\
\text { Limnephilidae }\end{array}$ \\
\hline
\end{tabular}


Table C.4 Mean monthly weight values $\left(\# / \mathbf{m}^{\mathbf{2}}\right) \pm$ standard deviation of individual benthic macroinvertebrates used to calculate weight frequency.

\begin{tabular}{|ll|}
\hline $\begin{array}{l}\text { Weights }(\mathrm{g}) \\
\text { Amphipoda } \\
\text { Gammarus }\end{array}$ & $\begin{array}{c}\text { Yearly Mean } \\
\mathrm{X} \pm \text { S.D. }\end{array}$ \\
\hline $\begin{array}{l}\text { 3asommatophora } \\
\text { Lymnaeidae }\end{array}$ & $0.0027 \pm 0.0021$ \\
$\quad$ Planorbidae & $0.1922 \pm 0.0001$ \\
Physidae & $0.0021 \pm 0.0001$ \\
\hline Jiptera & \\
Chironomidae pupae & \\
Chironomidae larvae & $0.0031 \pm 0.0021$ \\
Simuliidae & $0.0027 \pm 0.0079$ \\
\hline $\begin{array}{l}\text { Hydrachnellae } \\
\text { Hvdracarina }\end{array}$ & \\
\hline Jligochaeta & $0.0001 \pm 0.0001$ \\
Lumbriculidae & \\
\hline Pelecypoda & $0.0004 \pm 0.0002$ \\
Sphaeridae & \\
\hline Trichoptera & $0.0001 \pm 0.0001$ \\
Leptoceridae & \\
Limnephilidae & $0.0001 \pm 0.0001$ \\
Brachycentridae & $0.0009 \pm 0.0003$ \\
Odonata & $0.0004 \pm 0.0001$ \\
\hline & $0.0001 \pm 0.0001$ \\
\hline
\end{tabular}


APPENDIX D

WATER QUALITY 
No samples could be collected due to inclimate weather conditions at Gifford, Porcupine Bay, Seven Bays, and Spring Canyon in January. February, March, April, and May, and June samples were not collected due to equipment problems.

Table D.1 Water quality measurements taken with Hydrolab Surveyor II at Gifford, Porcupine Bay, Seven Bays, and Spring Canyon in July 1993.

\section{GIFFORD}

\begin{tabular}{|c|c|c|c|c|c|}
\hline $\begin{array}{l}\text { Depth } \\
(\mathrm{m})\end{array}$ & $\begin{array}{c}\text { Temp. } \\
\left({ }^{\circ} \mathrm{C}\right)\end{array}$ & pH & $\begin{array}{l}\text { D.O. } \\
/ \mathrm{L})\end{array}$ & $\begin{array}{l}\text { Conduct. } \\
\mathrm{mmho} / \mathrm{cm}\end{array}$ & $\begin{array}{l}\text { ORP } \\
\text { (V) }\end{array}$ \\
\hline 0 & 17.56 & 8.31 & 7.96 & .124 & .273 \\
\hline$\overline{3}$ & 17.02 & 8.28 & 7.80 & .124 & .273 \\
\hline 6 & 16.11 & 8.19 & 7.73 & .124 & .277 \\
\hline 9 & 15.96 & 8.14 & 7.75 & .124 & .277 \\
\hline$\overline{12}$ & 15.87 & 8.13 & 7.85 & .123 & .278 \\
\hline 15 & 15.48 & 8.12 & 7.82 & .122 & .279 \\
\hline 18 & 15.36 & 8.11 & 7.79 & .122 & .280 \\
\hline 21 & 15.31 & 8.09 & 7.73 & .122 & .281 \\
\hline 24 & 15.25 & 8.07 & 7.68 & .124 & .282 \\
\hline 27 & 15.23 & 8.06 & 7.74 & .124 & .287 \\
\hline 30 & 15.23 & $9 .^{\mathrm{NZ}}$ & 7.65 & .119 & .287 \\
\hline 33 & 15.21 & 8.05 & 7.59 & .125 & .288 \\
\hline 41 & 1522 & 803 & 7.38 & -123 & -290 \\
\hline
\end{tabular}

\section{PORCUPINE}

\begin{tabular}{|c|c|c|c|c|c|}
\hline $\begin{array}{c}\text { Depth } \\
(\mathbf{m})\end{array}$ & $\begin{array}{c}\text { Temp. } \\
\left({ }^{\circ} \mathbf{C}\right)\end{array}$ & $\mathbf{p H}$ & $\begin{array}{c}\text { D.O. } \\
(\mathbf{m g} / \mathbf{L})\end{array}$ & $\begin{array}{c}\text { Conduct. } \\
\mathbf{m m h o} / \mathbf{c m}\end{array}$ & $\begin{array}{c}\text { ORP } \\
(\mathbf{V})\end{array}$ \\
\hline 0 & 19.70 & 8.40 & 6.99 & .127 & .272 \\
\hline 3 & 19.13 & 8.31 & 6.93 & .129 & .270 \\
\hline 6 & 18.83 & 8.28 & 6.87 & .129 & .272 \\
\hline 9 & 18.36 & 8.11 & 6.56 & .133 & .278 \\
\hline 12 & 17.82 & 7.96 & 6.14 & .132 & .283 \\
\hline 15 & 17.37 & 7.86 & 5.88 & .121 & .285 \\
\hline 18 & 17.17 & 7.79 & 5.65 & .109 & .287 \\
\hline 21 & 16.56 & 7.72 & 5.55 & .096 & .289 \\
\hline 24 & 16.29 & 7.64 & 5.50 & .090 & .293 \\
\hline 27 & 15.53 & 7.57 & 5.35 & .088 & .296 \\
\hline 30 & 14.96 & 7.51 & 5.06 & .082 & .299 \\
\hline 33 & 13.62 & 7.39 & 4.75 & .079 & .304 \\
\hline
\end{tabular}


Table D.1 Continued;

SEVEN BAYS

\begin{tabular}{|c|c|c|c|c|c|}
\hline $\begin{array}{c}\text { Depth } \\
(\mathbf{m})\end{array}$ & $\begin{array}{c}\text { Temp. } \\
\left({ }^{\circ} \mathbf{C}\right)\end{array}$ & $\mathbf{p H}$ & $\begin{array}{c}\mathbf{D . O} \cdot \dot{(\mathbf{O}} \\
(\mathbf{m g} / \mathbf{L})\end{array}$ & $\begin{array}{c}\text { Conduct. } \\
\mathrm{mm} \mathrm{ho/cm}\end{array}$ & $\begin{array}{c}\text { ORP } \\
(\mathbf{V})\end{array}$ \\
\hline$. \phi-$, & 18.40 & 8.15 & 8.57 & .133 & .281 \\
\hline 3 & 17.94 & 8.30 & 8.40 & .123 & .280 \\
\hline 6 & 17.86 & 8.30 & 7.86 & .126 & .283 \\
\hline 9 & 17.76 & 8.28 & 7.64 & .125 & .284 \\
\hline 12 & 17.42 & 8.23 & 7.62 & .125 & .286 \\
\hline 15 & 17.30 & 8.19 & 7.56 & .124 & .287 \\
\hline 18 & 17.01 & 8.13 & 7.50 & .125 & .289 \\
\hline 21 & 16.93 & 8.10 & 7.42 & .125 & .290 \\
\hline 24 & 16.69 & 8.05 & 7.36 & .128 & .291 \\
\hline 27 & 16.63 & 8.03 & 7.36 & .128 & .293 \\
\hline 30 & 16.27 & 7.96 & 7.25 & .126 & .295 \\
\hline 33 & 16.11 & 7.93 & 7.22 & .126 & .296 \\
\hline 39 & 15.97 & 7.85 & 6.96 & .126 & .299 \\
\hline
\end{tabular}

SPRING CANYON

\begin{tabular}{|c|c|c|c|c|c|}
\hline $\begin{array}{c}\text { Depth } \\
(\mathbf{m})\end{array}$ & $\begin{array}{c}\text { Temp. } \\
\left({ }^{\circ} \mathbf{C}\right)\end{array}$ & $\mathbf{p H}$ & $\begin{array}{c}\mathbf{D . 0} . \\
(\mathbf{m g} / \mathbf{L})\end{array}$ & $\begin{array}{c}\text { Conduct. } \\
\text { mmho/cm }\end{array}$ & $\begin{array}{c}\text { ORP } \\
(\mathbf{V})\end{array}$ \\
\hline 0 & 19.93 & 8.06 & 7.32 & .121 & .277 \\
\hline 3 & 19.67 & 8.11 & 6.7 & .121 & .277 \\
\hline 6 & 19.05 & 8.15 & 6.78 & .121 & .279 \\
\hline 9 & 18.95 & 8.15 & 6.85 & .120 & .280 \\
\hline 12 & 18.88 & 8.13 & 6.85 & .120 & .281 \\
\hline 15 & 18.50 & 8.06 & 6.74 & .121 & .284 \\
\hline 18 & 17.81 & 8.03 & 6.82 & .122 & .286 \\
\hline 21 & 17.25 & 8.01 & 9.28 & .123 & .288 \\
\hline 24 & 16.93 & 7.97 & 9.31 & .124 & .289 \\
\hline 27 & 16.61 & 7.94 & 9.13 & .125 & .290 \\
\hline 30 & 19.36 & 8.96 & 6.668 .95 & .123 .120 & .278 .292 \\
\hline & & & & & \\
\hline
\end{tabular}


Table D.2 Water quality measurements taken with Hydrolab Surveyor II at Gifford, Porcupine Bay, Seven Bays, and Spring Canyon in August 1993.

\section{GIFFORD}

\begin{tabular}{|c|c|c|c|c|c|}
\hline $\begin{array}{c}\text { Depth } \\
(\mathbf{m})\end{array}$ & $\begin{array}{c}\text { Temp. } \\
\left({ }^{\circ} \mathbf{C}\right)\end{array}$ & $\mathbf{p H}$ & $\begin{array}{c}\text { D.O. } \\
(\mathbf{m g} / \mathbf{L})\end{array}$ & $\begin{array}{c}\text { Conduct. } \\
\text { mmho/cm }\end{array}$ & $\begin{array}{c}\text { ORP } \\
(\mathbf{V})\end{array}$ \\
\hline 0 & 19.53 & 7.46 & 7.59 & .126 & .254 \\
\hline 3 & 19.31 & 7.46 & 8.25 & .128 & .254 \\
\hline 6 & 19.26 & 7.45 & 8.33 & .126 & .255 \\
\hline 9 & 18.81 & 7.35 & 8.26 & .125 & .259 \\
\hline 12 & 18.73 & 7.31 & 8.23 & .125 & .260 \\
\hline 15 & 18.46 & 7.27 & 8.24 & .124 & .261 \\
\hline 18 & 18.32 & 7.22 & 8.15 & .124 & .263 \\
\hline 21 & 18.26 & 7.15 & 8.19 & .126 & .264 \\
\hline 24 & 18.20 & 7.16 & 7.58 & .126 & .270 \\
\hline 27 & 18.06 & 7.14 & 7.94 & .124 & .272 \\
\hline 30 & 17.80 & 7.13 & 8.05 & .124 & .272 \\
\hline 33 & 17.66 & 7.12 & 7.98 & .126 & .273 \\
\hline
\end{tabular}

PORCUPINE

\begin{tabular}{|c|c|c|c|c|c|}
\hline $\begin{array}{c}\text { Depth } \\
(\mathbf{m})\end{array}$ & $\begin{array}{c}\text { Te m p } \\
\left({ }^{\circ} \mathbf{C}\right)\end{array}$ & $\mathbf{p H}$ & $\begin{array}{c}\text { D.O. } \\
(\mathbf{m g} / \mathbf{L})\end{array}$ & $\begin{array}{c}\text { Conduct. } \\
\mathbf{m m h o} / \mathbf{c m}\end{array}$ & $\begin{array}{c}\text { ORP } \\
(\mathbf{V})\end{array}$ \\
\hline 0 & 21.22 & 7.80 & 7.64 & .138 & .235 \\
\hline 3 & 21.11 & 7.79 & 8.09 & .138 & .235 \\
\hline 6 & 20.97 & 7.79 & 8.72 & .138 & .235 \\
\hline 9 & 20.02 & 7.61 & 9.32 & .136 & .245 \\
\hline 12 & 19.22 & 7.42 & 9.23 & .134 & .250 \\
\hline 15 & 18.93 & 7.19 & 8.85 & .133 & .255 \\
\hline 18 & 18.50 & 7.10 & 8.77 & .134 & .258 \\
\hline 21 & 18.01 & 6.99 & 8.75 & .134 & .261 \\
\hline 24 & 17.25 & 6.94 & 8.06 & .129 & .264 \\
\hline 27 & 16.09 & 6.91 & 6.99 & .100 & .266 \\
\hline 30 & 15.54 & 6.76 & 3.41 & .091 & .279 \\
\hline 33 & & & & & \\
\hline
\end{tabular}


Table D.2 Continued;

SEVEN BAYS

\begin{tabular}{|c|c|c|c|c|c|}
\hline $\begin{array}{c}\text { Depth } \\
(\mathbf{m})\end{array}$ & $\begin{array}{c}\text { Temp. } \\
\left({ }^{\circ} \mathbf{C}\right)\end{array}$ & $\mathbf{p H}$ & $\begin{array}{c}\text { D.O. } \\
(\mathbf{m} \mathbf{g} / \mathbf{L})\end{array}$ & $\begin{array}{c}\text { Conduct. I } \\
\mathbf{m m h} / \mathbf{c m}\end{array}$ & $\begin{array}{c}\text { ORP } \\
(\mathbf{V})\end{array}$ \\
\hline 0 & 20.27 & 7.32 & 8.29 & .129 & .277 \\
\hline 3 & 20.26 & 7.32 & 8.31 & .129 & .277 \\
\hline 6 & 20.26 & 7.34 & 8.35 & .129 & .277 \\
\hline 9 & 20.21 & 7.35 & 8.39 & .130 & .277 \\
\hline 12 & 19.56 & 7.29 & 8.37 & .127 & .280 \\
\hline 15 & 19.24 & 7.22 & 8.37 & .129 & .281 \\
\hline 18 & 18.70 & 7.19 & 8.42 & .128 & .282 \\
\hline 21 & 18.47 & 7.17 & 8.43 & .129 & .283 \\
\hline 24 & 17.78 & 7.14 & 8.49 & .126 & .285 \\
\hline 27 & 17.32 & 7.11 & 8.47 & .127 & .286 \\
\hline 30 & 17.20 & 7.06 & 8.43 & .125 & .287 \\
\hline 33 & 16.95 & 7.02 & 8.27 & .123 & .289 \\
\hline
\end{tabular}

\begin{tabular}{|c|c|c|c|c|c|}
\hline $\begin{array}{c}\text { Depth } \\
(\mathbf{m})\end{array}$ & $\begin{array}{c}\text { Temp. } \\
\left({ }^{\circ} \mathbf{C}\right)\end{array}$ & $\mathbf{p H}$ & $\begin{array}{c}\text { D.O. } \\
(\mathbf{m g} / \mathbf{L})\end{array}$ & $\begin{array}{c}\text { Conduct. } \\
\text { mm ho/cm }\end{array}$ & $\begin{array}{c}\text { ORP } \\
(\mathbf{V})\end{array}$ \\
\hline 0 & 21.61 & 7.46 & 7.98 & .125 & .260 \\
\hline 3 & 21.61 & 7.46 & 8.11 & .124 & .261 \\
\hline 6 & 21.56 & 7.48 & 8.17 & .125 & .261 \\
\hline 9 & 21.54 & 7.47 & 8.25 & .126 & .261 \\
\hline 12 & 20.86 & 7.41 & 8.07 & .124 & .264 \\
\hline 15 & 19.84 & 7.30 & 8.10 & .125 & .267 \\
\hline 18 & 19.54 & 7.20 & 7.98 & .126 & .270 \\
\hline 21 & 18.61 & 7.15 & 7.95 & .124 & .272 \\
\hline 24 & 17.71 & 7.08 & 7.94 & .128 & .274 \\
\hline 27 & 17.17 & 7.04 & 7.96 & .124 & .276 \\
\hline 30 & 16.08 & 6.98 & 8.06 & .126 & .277 \\
\hline 33 & 16.57 & 6.94 & 8.03 & .127 & .279 \\
\hline
\end{tabular}


Table D.3 Water quality measurements taken with Hydrolab

Surveyor II at Gifford and Porcupine Bay in September

1993.

\section{GIFFORD}

\begin{tabular}{|c|c|c|c|c|c|}
\hline $\begin{array}{c}\text { Depth } \\
(\mathbf{m})\end{array}$ & $\begin{array}{c}\text { Temp. } \\
\left({ }^{\circ} \mathbf{C}\right)\end{array}$ & $\mathbf{p H}$ & $\begin{array}{c}\mathbf{D} . \mathbf{O} \\
(\mathbf{m g} / \mathbf{L})\end{array}$ & $\begin{array}{c}\text { Conduct. } \\
\text { mm ho/cm }\end{array}$ & $\begin{array}{c}\text { ORP } \\
(\mathbf{V})\end{array}$ \\
\hline 0 & 16.25 & 8.28 & 12.85 & 134.9 & 243 \\
\hline 3 & 16.28 & 7.83 & 9.94 & 134.7 & 243 \\
\hline 6 & 16.28 & 7.68 & 9.65 & 134.8 & 242 \\
\hline 9 & 16.26 & 7.62 & 9.46 & 134.3 & 243 \\
\hline 12 & 16.16 & 7.59 & 9.40 & 135.8 & 244 \\
\hline 15 & 16.15 & 7.58 & 9.37 & 135.7 & 245 \\
\hline 18 & 16.15 & 7.57 & 9.33 & 136.5 & 245 \\
\hline 21 & 16.15 & 7.57 & 9.31 & 137.2 & 245 \\
\hline 24 & 16.13 & 7.56 & 9.29 & 137.8 & 246 \\
\hline 27 & 16.05 & 7.55 & 9.27 & 139.4 & 247 \\
\hline 30 & 15.98 & 7.52 & 9.25 & 137.9 & 248 \\
\hline 33 & 15.96 & 7.51 & 9.26 & 139.2 & 249 \\
\hline
\end{tabular}

PORCUPINE

\begin{tabular}{|c|c|c|c|c|c|}
\hline $\begin{array}{c}\text { Depth } \\
(\mathbf{m})\end{array}$ & $\begin{array}{c}\text { Temp. } \\
\left({ }^{\circ} \mathbf{C}\right)\end{array}$ & $\mathbf{p H}$ & $\begin{array}{c}\text { D.O. } \\
(\mathbf{m g} / \mathbf{L})\end{array}$ & $\begin{array}{c}\text { Conduct. } \\
\mathbf{m m h o} / \mathbf{c m}\end{array}$ & $\begin{array}{c}\text { ORP } \\
(\mathbf{V})\end{array}$ \\
\hline 0 & 17.27 & 7.94 & 14.38 & 155 & 241 \\
\hline 3 & 17.29 & 7.41 & 8.41 & 150 & 241 \\
\hline 6 & 17.29 & 7.36 & 8.28 & 151 & 242 \\
\hline 9 & 17.29 & 7.34 & 8.21 & 155 & 242 \\
\hline 12 & 17.26 & 7.32 & 8.11 & 154 & 243 \\
\hline 15 & 17.24 & 7.31 & 8.03 & 156 & 244 \\
\hline 18 & 17.12 & 7.25 & 7.96 & 165 & 246 \\
\hline 21 & 16.82 & 7.23 & 7.60 & 172 & 247 \\
\hline 24 & 16.35 & 7.19 & 7.52 & 163 & 249 \\
\hline 27 & 16.23 & 7.15 & 7.10 & 165 & 251 \\
\hline 30 & & & & & \\
\hline 55 & & & & & \\
\hline
\end{tabular}

Data was not collected at Gifford, Seven Bays, and Spring Canyon on September. 
Table D.4 Water quality measurements taken with Hydrolab Surveyor II at Seven Bays-and Spring Canyon in October 1993.

SEVEN BAYS

\begin{tabular}{|c|c|c|c|c|c|}
\hline $\begin{array}{c}\text { Depth } \\
(\mathbf{m})\end{array}$ & $\begin{array}{c}\text { Temp. } \\
\left({ }^{\circ} \mathbf{C}\right)\end{array}$ & $\mathbf{p H}$ & $\begin{array}{c}\text { D. O. } \\
(\mathbf{m g} / \mathbf{L})\end{array}$ & $\begin{array}{c}\text { Conduct. } \\
\mathbf{m m h o} / \mathbf{c m}\end{array}$ & $\begin{array}{c}\text { ORP } \\
(\mathbf{V})\end{array}$ \\
\hline 0 & 3.73 & 7.81 & 13.03 & 139.1 & 396 \\
\hline 3 & 3.73 & 7.84 & 13.05 & 139.3 & 396 \\
\hline 6 & 3.71 & 7.85 & 13.03 & 139.8 & 396 \\
\hline 9 & 3.73 & 7.85 & 12.98 & 140.7 & 398 \\
\hline 12 & 3.73 & 7.85 & 12.96 & 140.8 & 398 \\
\hline 15 & 3.73 & 7.86 & 12.90 & 141.9 & 399 \\
\hline 18 & 3.73 & 7.86 & 12.88 & 139.3 & 399 \\
\hline 21 & 3.73 & 7.86 & 12.83 & 138.6 & 400 \\
\hline 24 & 3.73 & 7.87 & 12.79 & 144.6 & 401 \\
\hline 27 & 3.74 & 7.86 & 12.78 & 138.6 & 402 \\
\hline 30 & 3.74 & 7.86 & 12.76 & 139.4 & 403 \\
\hline 33 & 3.74 & 7.86 & 12.72 & 140.8 & 403 \\
\hline
\end{tabular}

, SPRING CANYON

\begin{tabular}{|c|c|c|c|c|c|}
\hline $\begin{array}{c}\text { Depth } \\
(\mathbf{m})\end{array}$ & $\begin{array}{c}\text { Te m p } \\
\left({ }^{\circ} \mathbf{C}\right)\end{array}$ & $\mathbf{p H}$ & $\begin{array}{c}\text { D.O. } \\
(\mathbf{m g} / \mathbf{L})\end{array}$ & $\begin{array}{c}\text { Conduct. } \\
\mathbf{m m h o} / \mathbf{c m}\end{array}$ & $\begin{array}{c}\text { ORP } \\
(\mathbf{V})\end{array}$ \\
\hline 0 & 5.34 & 7.79 & 12.36 & 135.6 & 423 \\
\hline 3 & 5.27 & 7.81 & 12.06 & 134.9 & 431 \\
\hline 6 & 5.22 & 7.83 & 11.91 & 135.3 & 435 \\
\hline 9 & 5.19 & 7.84 & 11.76 & 135.9 & 437 \\
\hline 12 & 5.14 & 7.84 & 11.40 & 135 & 441 \\
\hline 15 & 5.09 & 7.85 & 11.41 & 136.8 & 441 \\
\hline 18 & 5.09 & 7.85 & 11.64 & 133.6 & 442 \\
\hline 21 & 5.10 & 7.85 & 11.66 & 136.6 & 443 \\
\hline 24 & 5.09 & 7.85 & 11.66 & 137.5 & 444 \\
\hline 27 & 5.09 & 7.85 & 11.68 & 135.7 & 444 \\
\hline 30 & 5.09 & 7.85 & 11.66 & 138.8 & 445 \\
\hline 33 & 5.05 & 7.85 & 11.59 & 134.8 & 445 \\
\hline
\end{tabular}

Data was not collected at Gifford and Porcupine Bay in October. 
Table D.5 Water quality measurements taken with Hydrolab Surveyor II at Gifford, Porcupine Bay, Seven Bays, and Spring Canyon in November 1993.

\begin{tabular}{|c|c|c|c|c|c|}
\hline \multicolumn{6}{|c|}{ SPRING CANYON } \\
\hline $\begin{array}{c}\text { Depth } \\
\text { (m) }\end{array}$ & $\begin{array}{l}\text { Temp } \\
\left({ }^{\circ} \mathbf{C}\right)\end{array}$ & $\mathbf{p H}$ & $\begin{array}{c}\text { D.O. } \\
(\mathrm{mg} / \mathrm{L}) \mid\end{array}$ & $\begin{array}{l}\text { TConduct. } \\
\mathrm{mmho/cm}\end{array}$ & $\begin{array}{l}\text { ORP } \\
\text { (V) }\end{array}$ \\
\hline$\varnothing$ & 13.26 & 7.36 & 11.24 & $\begin{array}{ll}139.3 \\
\end{array}$ & 335 \\
\hline 3 & 13.28 & 7.45 & 10.66 & 139.2 & 331 \\
\hline 6 & 13.29 & 7.60 & 10.0 & 139.4 & 327 \\
\hline te & $\begin{array}{ll}-1230 \\
1\end{array}$ & 7.64 & 9.95 & 139.2 & 326 \\
\hline 12 & 13.29 & 7.65 & 9.98 & 1211 & 325 \\
\hline 15 & 13.29 & 7.67 & 9.81 & 141!G & 325 \\
\hline 18 & 13.29 & 7.68 &. .077 & 139.6 & 325 \\
\hline 21 & 13.29 & 7.69 & 9.74 & 141.0 & 324 \\
\hline 24 & 13229 & 7.71 & $\overline{9.72}$ & 143.1 & $32 \underline{3}$ \\
\hline & & 1.71 & 9.68 & 143.1 & $\overline{324}$ \\
\hline$\overline{30}$ & 10.673 .29 & 7.71 & 9.69 & 138.4 & 323 \\
\hline 33 & 1320 & 773 & 971 & 1392 & 323 \\
\hline
\end{tabular}


Table D.5 Water quality measurements taken with Hydrolab Surveyor II at Gifford, Porcupine Bay, Seven Bays, and Spring Canyon in December 1993.

\section{GIFFORD}

\begin{tabular}{|c|c|c|c|c|c|}
\hline $\begin{array}{c}\text { Depth } \\
(\mathbf{m})\end{array}$ & $\begin{array}{c}\text { Temp. } \\
\left({ }^{\circ} \mathbf{C}\right)\end{array}$ & $\mathbf{p H}$ & $\begin{array}{c}\mathbf{D} \mathbf{0} \cdot \mathbf{(}) \\
(\mathbf{m g} / \mathbf{L})\end{array}$ & $\begin{array}{c}\text { Conduct. } \\
\text { mm ho/cm }\end{array}$ & $\begin{array}{c}\text { ORP } \\
(\mathbf{V})\end{array}$ \\
\hline 0 & 3.89 & 7.75 & 1006 & 145.3 & 323 \\
\hline 3 & 3.94 & 7.75 & 14.75 & 145.1 & 318 \\
\hline 6 & 3.98 & 7.76 & 14.40 & 145.6 & 316 \\
\hline 9 & 3.96 & 7.78 & 14.29 & 145.6 & 315 \\
\hline 12 & 3.98 & 7.79 & 14.18 & 146.5 & 315 \\
\hline 15 & 3.99 & 7.81 & 14.08 & 144.3 & 314 \\
\hline 18 & 3.98 & 7.82 & 13.97 & 145.7 & 314 \\
\hline 21 & 3.98 & 7.82 & 13.88 & 144.0 & 314 \\
\hline 24 & 3.99 & 7.83 & 13.77 & 147.1 & 313 \\
\hline 27 & 3.99 & 7.84 & 13.73 & 141.9 & 313 \\
\hline 30 & 3.99 & 7.84 & 13.64 & 144.5 & 313 \\
\hline 33 & 3.98 & 7.85 & 13.55 & 143.9 & 313 \\
\hline
\end{tabular}

PORCUPINE

\begin{tabular}{|c|c|c|c|c|c|}
\hline $\begin{array}{c}\text { Depth } \\
(\mathbf{m})\end{array}$ & $\begin{array}{c}\text { Temp. } \\
\left({ }^{\circ} \mathbf{C}\right)\end{array}$ & $\mathbf{p H}$ & $\begin{array}{c}\mathbf{D . O} . \\
(\mathbf{m g} / \mathbf{L})\end{array}$ & $\begin{array}{c}\text { Conduct. } \\
\mathbf{m m h o} / \mathbf{c m}\end{array}$ & $\begin{array}{c}\text { ORP } \\
(\mathbf{V})\end{array}$ \\
\hline 0 & 4.69 & 7.69 & 17.11 & 172 & 311 \\
\hline 3 & 4.76 & 7.66 & 13.61 & 181 & 310 \\
\hline 6 & 4.76 & 7.67 & 12.39 & 169 & 311 \\
\hline 9 & 4.74 & 7.69 & 11.99 & 168 & 312 \\
\hline 12 & 4.76 & 7.71 & 11.84 & 170 & 314 \\
\hline 15 & 4.74 & 7.73 & 11.73 & 159 & 315 \\
\hline 18 & 4.69 & 7.76 & 11.63 & 169 & 316 \\
\hline 21 & 4.67 & 7.77 & 11.56 & 183 & 317 \\
\hline 24 & 4.64 & 7.77 & 11.39 & 188 & 319 \\
\hline 27 & & & & & \\
\hline 30 & & & & & \\
\hline 33 & & & & & \\
\hline \hline
\end{tabular}


Table D.6 Continued;

SEVEN BAYS

\begin{tabular}{|c|c|c|c|c|c|}
\hline $\begin{array}{c}\text { Depth } \\
(\mathbf{m})\end{array}$ & $\begin{array}{c}\text { Temp. } \\
\left({ }^{\circ} \mathbf{C}\right)\end{array}$ & $\mathbf{p H}$ & $\begin{array}{c}\mathbf{D} . \mathbf{O} \\
(\mathbf{m g} / \mathbf{L})\end{array}$ & $\begin{array}{c}\text { Conduct. } \\
\mathbf{m m h o} / \mathbf{c m}\end{array}$ & $\begin{array}{c}\text { ORP } \\
(\mathbf{V})\end{array}$ \\
\hline 0 & 3.61 & 7.82 & 17.28 & 145.9 & 284 \\
\hline 3 & 3.71 & 7.83 & 15.18 & 145.7 & 283 \\
\hline 6 & 3.71 & 7.82 & 14.26 & 145.8 & 281 \\
\hline 9 & 3.73 & 7.82 & 13.94 & 146.4 & 280 \\
\hline 12 & 3.74 & 7.83 & 13.68 & 147.5 & 280 \\
\hline 15 & 3.74 & 7.83 & 13.44 & 147.3 & 280 \\
\hline 18 & 3.76 & 7.83 & 13.35 & 143.4 & 280 \\
\hline 21 & 3.76 & 7.83 & 13.21 & 147.4 & 280 \\
\hline 24 & 3.80 & 7.84 & 13.17 & 144.0 & 280 \\
\hline 27 & 3.83 & 7.85 & 13.10 & 146.9 & 280 \\
\hline 30 & 3.83 & 7.85 & 13.04 & 147.4 & 280 \\
\hline 33 & 3.83 & 7.86 & 12.99 & 144.9 & 280 \\
\hline
\end{tabular}

SPRING CANYON

\begin{tabular}{|c|c|c|c|c|c|}
\hline $\begin{array}{c}\text { Depth } \\
(\mathbf{m})\end{array}$ & $\begin{array}{c}\text { Temp. } \\
\left({ }^{\circ} \mathbf{C}\right)\end{array}$ & $\mathbf{p H}$ & $\begin{array}{c}\text { D.O. } \\
(\mathbf{m g} / \mathbf{L})\end{array}$ & $\begin{array}{c}\text { Conduct. } \\
\mathbf{m m h o} / \mathbf{c m}\end{array}$ & $\begin{array}{c}\text { ORP } \\
(\mathbf{V})\end{array}$ \\
\hline 0 & 6.67 & 7.84 & 15.50 & 142.3 & 292 \\
\hline 3 & 6.72 & 7.80 & 13.07 & 142.4 & 289 \\
\hline 6 & 6.71 & 7.81 & 12.54 & 143.4 & 286 \\
\hline 9 & 6.72 & 7.82 & 12.22 & 143.1 & 285 \\
\hline 12 & 6.71 & 7.84 & 12.01 & 141.4 & 284 \\
\hline 15 & 6.74 & 7.85 & 11.90 & 141.5 & 284 \\
\hline 18 & 6.74 & 7.86 & 11.85 & 142.2 & 283 \\
\hline 21 & 6.59 & 7.86 & 11.80 & 143.1 & 283 \\
\hline 24 & 6.54 & 7.87 & 11.77 & 140.0 & 283 \\
\hline 27 & 6.36 & 7.87 & 11.77 & 140.0 & 283 \\
\hline 30 & 6.11 & 7.88 & 11.87 & 144.4 & 284 \\
\hline 33 & 6.09 & 7.88 & 11.88 & 143.0 & 283 \\
\hline
\end{tabular}


Table E.1 Record of tagging releases from all net-pen tagging efforts on Lake Roosevelt from 1986 to present.

\begin{tabular}{|c|c|c|c|c|c|}
\hline DATE & $\begin{array}{l}\text { LOC } \\
\text { CODE }\end{array}$ & $\begin{array}{l}\text { NUMBER } \\
\text { TAGGED }\end{array}$ & SPECIES & $\begin{array}{c}\text { TAG } \\
\text { COLOR }\end{array}$ & $\begin{array}{c}\text { NUMBER } \\
\text { SERIES }\end{array}$ \\
\hline$\overline{4 / 13 / 89}$ & $\overline{\overline{0-\mathrm{NP}}}$ & $\overline{495}$ & $\overline{\overline{\mathrm{R}}}$ & $\overline{\bar{Y}}$ & 22101-22601 \\
\hline $5 / 12 / 87$ & $1-N P$ & 25 & $\mathrm{R}$ & 0 & $26-50$ \\
\hline $\begin{array}{c}9 / 27 / 89 \\
9 / 27 / 89 \\
\mathbf{9 / 2 7 / 8 9}\end{array}$ & 11 -NP.NP & $\begin{array}{r}390194 \\
\mathbf{5 8 4}\end{array}$ & $R R$ & $\begin{array}{l}\text { O } \\
\text { O }\end{array}$ & $15101-15229915601-16000$ \\
\hline $\begin{array}{c}3 / 27 / 90 \\
3 / 27 / 90 \\
3 / 27 / 90\end{array}$ & $\begin{array}{l}11-N P \cdot N P \\
1-N P\end{array}$ & $\begin{array}{l}5026 \\
508\end{array}$ & $\begin{array}{l}\mathrm{R} \\
\mathrm{R}\end{array}$ & $\begin{array}{l}\mathrm{O} \\
\mathrm{O}\end{array}$ & $\begin{array}{lll}33500-33500 & 33978-33983\end{array}$ \\
\hline $\begin{array}{l}4 / 19 / 90 \\
4 / 17 / 91 \\
3 / 22 / 92 \\
4 / 26 / 92 \\
5 / 24 / 92\end{array}$ & $\begin{array}{l}1-N P \\
1-N P \\
1-N P \\
1-N P \\
1-N P\end{array}$ & $\begin{array}{l}498 \\
1000 \\
1000 \\
1000 \\
\mathbf{1 0 0 0}\end{array}$ & $\begin{array}{l}\mathrm{R} \\
\mathrm{R} \\
\mathrm{R} \\
\mathrm{R}\end{array}$ & $\begin{array}{l}\mathrm{O} \\
\mathrm{O} \\
\mathrm{P} \\
\mathrm{P} \\
\mathrm{P}\end{array}$ & $\begin{array}{c}38001-38500 \\
44001-45000 \\
0001-1000 \\
1001-2000 \\
12001-13000\end{array}$ \\
\hline $\begin{array}{l}3 / 22 / 92 \\
4 / 26 / 92 \\
5 / 24 / 92 \\
6 / 11 / 92 \\
4 / 20 / 93 \\
5 / 27 / 93\end{array}$ & $\begin{array}{l}\text { HC-NP } \\
\text { HC-NP } \\
\text { HC-NP } \\
\text { HC-NP } \\
\text { HC-NP } \\
\text { HC-NP }\end{array}$ & $\begin{array}{l}1000 \\
1000 \\
1000 \\
1000 \\
999 \\
1000\end{array}$ & $\begin{array}{l}\mathrm{R} \\
\mathrm{R} \\
\mathrm{R} \\
\mathrm{R} \\
\mathrm{R} \\
\mathrm{R}\end{array}$ & $\begin{array}{l}0 \\
\mathrm{P} \\
\mathrm{P} \\
\mathrm{P} \\
\mathrm{O} \\
0\end{array}$ & $\begin{array}{c}65001-66000 \\
2001-2000 \\
11001-12000 \\
13001-14000 \\
32001-33000 \\
37001-38000\end{array}$ \\
\hline $\begin{array}{l}3 / 10 / 89 \\
10 / 7 / 89 \\
3 / 29 / 90 \\
4 / 19 / 90 \\
5 / 19 / 90\end{array}$ & $\begin{array}{l}\text { 3-NP } \\
\text { 3-NP } \\
\text { 3-NP } \\
\text { 3-NP } \\
3-N P\end{array}$ & $\begin{array}{l}768 \\
447 \\
490 \\
498 \\
492\end{array}$ & $\begin{array}{l}\mathrm{R} \\
\mathrm{R} \\
\mathrm{R} \\
\mathrm{R} \\
\mathrm{R}\end{array}$ & $\begin{array}{l}\mathrm{O} \\
\mathrm{O} \\
0 \\
\mathrm{O} \\
\mathrm{O}\end{array}$ & $\begin{array}{l}24151-25000 \\
17001-17500 \\
34001-34500 \\
37001-37500 \\
38501-39000\end{array}$ \\
\hline $\begin{array}{c}10 / 24 / 90 \\
10 / 24 / 90 \\
\mathbf{1 0} / \mathbf{2 4 / 9 0}\end{array}$ & $\begin{array}{l}3-N P \\
3-N P \\
\mathbf{3}-\mathbf{N P}\end{array}$ & $\begin{array}{c}124 \\
59 \\
183\end{array}$ & $\begin{array}{l}R \\
R\end{array}$ & O & $\begin{array}{l}46001-46129 \\
46267-46325\end{array}$ \\
\hline
\end{tabular}


Table E.1 Continued

\begin{tabular}{|c|c|c|c|c|c|}
\hline$\overline{\text { DATE }}$ & $\begin{array}{c}\text { LOC } \\
\text { CODE }\end{array}$ & $\begin{array}{l}\text { NUMBER } \\
\text { TAGGED }\end{array}$ & SPECIES & $\begin{array}{c}\text { TAG } \\
\text { COLOR }\end{array}$ & $\begin{array}{l}\text { NUMBER } \\
\text { SERIES }\end{array}$ \\
\hline $\begin{array}{l}3 / 21792 \\
4 / 25 / 92 \\
5 / 23 / 92 \\
9 / 24 / 92 \\
4 / 20 / 93 \\
5 / 20 / 93\end{array}$ & $\begin{array}{l}\text { 3-NP } \\
\text { 3-NP } \\
\text { 3-NP } \\
\text { 3-NP } \\
\text { 3-NP } \\
\text { 3-NP }\end{array}$ & $\begin{array}{l}\mathbf{1 0 0 0} \\
1000 \\
1000 \\
1000 \\
999 \\
999\end{array}$ & $\begin{array}{l}\mathrm{R} \\
\mathrm{R} \\
\mathrm{R} \\
\mathrm{R} \\
\mathrm{R} \\
\mathrm{R}\end{array}$ & $\begin{array}{l}\mathrm{O} \\
\mathrm{P} \\
\mathrm{P} \\
\mathrm{P} \\
\mathrm{P} \\
\mathrm{P}\end{array}$ & $\begin{array}{c}\mathbf{6 1 0 0 1 - 6 2 0 0 0} \\
5001-6000 \\
10001-11000 \\
16001-17000 \\
31001-32000 \\
34001-35000\end{array}$ \\
\hline $\begin{array}{c}3 / 17 / 92 \\
3 / 17 / 92 \\
\mathbf{3} / \mathbf{1 7 / 9 2}\end{array}$ & $\begin{array}{l}5-\mathrm{HR} \\
5 \text {-HR } \\
5-\mathrm{HR}\end{array}$ & $\begin{array}{c}971 \\
961 \\
1932\end{array}$ & $\begin{array}{l}\mathrm{R} \\
\mathrm{R}\end{array}$ & $\begin{array}{l}\bar{Y} \\
Y\end{array}$ & $\begin{array}{l}50001-51000 \\
51001-52000\end{array}$ \\
\hline $5 / 15 / 90$ & $\overline{\overline{5-T N P}}$ & $\overline{426}$ & $\overline{\overline{\mathrm{R}}}$ & $\overline{\bar{Y}}$ & "18576-19000 \\
\hline $\begin{array}{c}5 / 4 / 88 \\
5 / 4 / 88 \\
5 / 4 / 88\end{array}$ & $\begin{array}{l}6-N P \\
6-N P \\
6-N P\end{array}$ & $\begin{array}{c}175 \\
996 \\
1171\end{array}$ & $\begin{array}{l}\overline{\overline{\mathrm{R}}} \\
\mathrm{R} \\
\mathrm{R}\end{array}$ & $\begin{array}{l}\mathrm{O} \\
\mathrm{O}\end{array}$ & $\begin{array}{l}10751-11000 \\
11001-12000\end{array}$ \\
\hline $\begin{array}{l}4 / 12 / 89 \\
12 / 21 / 89 \\
3 / 22 / 90 \\
4 / 17 / 90 \\
5 / 26 / 90 \\
5 / 26 / 90 \\
7 / 13 / 90\end{array}$ & $\begin{array}{l}6-N P \\
6-N P \\
6-N P \\
6-N P \\
6-N P \\
6-N P \\
6-N P\end{array}$ & $\begin{array}{c}985 \\
496 \\
443 \\
474 \\
499 \\
925 \\
50\end{array}$ & $\begin{array}{c}\mathrm{R} \\
\text { KAM } \\
\mathrm{R} \\
\mathrm{R} \\
\mathrm{R} \\
\mathrm{KAM} \\
\mathrm{R}\end{array}$ & $\begin{array}{l}0 \\
\mathrm{~B} \\
\mathrm{O} \\
\mathrm{O} \\
\mathrm{O} \\
\mathrm{B} \\
0\end{array}$ & $\begin{array}{c}26001-27000 \\
21001-21500 \\
25201-25700 \\
33501-33977 \\
39001-39500 \\
55001-55975 \\
37501-3755\end{array}$ \\
\hline $\begin{array}{c}4 / 17 / 91 \\
4 / 17 / 91 \\
4 / 17 / 91\end{array}$ & $\begin{array}{l}\text { 6-NP } \\
\text { 6-NP } \\
\mathbf{6 - N P}\end{array}$ & $\begin{array}{c}300 \\
1000 \\
1300\end{array}$ & $\begin{array}{l}\mathrm{R} \\
\mathrm{R} \\
\mathrm{R}\end{array}$ & $\begin{array}{l}\mathrm{O} \\
\mathrm{O}\end{array}$ & $\begin{array}{l}47001-47300 \\
45001-46000\end{array}$ \\
\hline $4 / 17 / 91$ & 6-NP & 200 & KAM & 0 & $47301-47500$ \\
\hline $\begin{array}{l}6 / 6 / 91 \\
6 / 6 / 91 \\
6 / 6 / 91\end{array}$ & $\begin{array}{l}\text { 6-NP } \\
\text { 6-NP } \\
\text { 6-NP }\end{array}$ & $\begin{array}{c}50 \\
246 \\
296\end{array}$ & $\begin{array}{l}\mathrm{R} \\
\mathrm{R} \\
\mathrm{R}\end{array}$ & $\begin{array}{l}\mathrm{O} \\
\mathrm{O}\end{array}$ & $\begin{array}{l}46201-46250 \\
46326-467 \quad 10\end{array}$ \\
\hline $6 / 6 / 91$ & 6-NP & 575 & KAM & B & $46126-47000$ \\
\hline $\begin{array}{l}7 / 13 / 91 \\
7 / 13 / 91 \\
7 / 13 / 91\end{array}$ & $\begin{array}{l}\text { 6-NP } \\
6-N P \\
6-N P\end{array}$ & $\begin{array}{c}190 \\
495 \\
75\end{array}$ & $\begin{array}{l}\mathrm{R} \\
\mathrm{R} \\
\mathrm{R}\end{array}$ & $\begin{array}{l}0 \\
0 \\
0\end{array}$ & $\begin{array}{l}467 \quad 1 \quad 1-46900 \\
47501-48000 \\
17726-17800\end{array}$ \\
\hline
\end{tabular}


Table E.1 Continued

\begin{tabular}{|c|c|c|c|c|c|}
\hline$\overline{\text { DATE }}$ & $\begin{array}{c}\text { LOC } \\
\text { CODE }\end{array}$ & $\begin{array}{l}\text { NUMBER } \\
\text { TAGGED }\end{array}$ & SPECIES & $\begin{array}{c}\text { TAG } \\
\text { COLOR }\end{array}$ & $\begin{array}{l}\text { NUMBER } \\
\text { SERIES }\end{array}$ \\
\hline $\begin{array}{c}7 / 13 / 91 \\
7 / 13 / 91\end{array}$ & $\begin{array}{l}\text { 6-NP } \\
\text { 6-NP }\end{array}$ & $\begin{array}{c}989 \\
1749\end{array}$ & $\begin{array}{l}\mathrm{R} \\
\mathrm{R} \\
\mathrm{R}\end{array}$ & $\varnothing$ & $48001-49000$ \\
\hline $\begin{array}{c}3 / 20 / 92 \\
4 / 25 / 92 \\
5 / 23 / 92 \\
6 / 16 / 92 \\
4 / 19 / 93 \\
5 / 26 / 93 \\
6 / 7 / 93\end{array}$ & $\begin{array}{l}\text { 6-NP } \\
6-N P \\
6-N P \\
6-N P \\
6-N P \\
6-N P \\
6-N P\end{array}$ & $\begin{array}{l}999 \\
1000 \\
1000 \\
1000 \\
997 \\
1000 \\
296\end{array}$ & $\begin{array}{l}\mathrm{R} \\
\mathrm{R} \\
\mathrm{R} \\
\mathrm{R} \\
\mathrm{R} \\
\mathrm{R}\end{array}$ & $\begin{array}{l}\emptyset \\
P \\
P \\
P \\
P\end{array}$ & $\begin{array}{c}62001-63000 \\
4001-5000 \\
9001-10000 \\
14001-15000 \\
30001-31000 \\
35001-36000\end{array}$ \\
\hline $\begin{array}{l}3 / 21 / 92 \\
5 / 22 / 92 \\
6 / 18 / 92\end{array}$ & $\begin{array}{l}\text { L-NP } \\
\text { L-NP } \\
\text { L-NP L-NP }\end{array}$ & $\begin{array}{l}1000 \\
1000 \\
1000600\end{array}$ & $\begin{array}{l}\mathrm{R} \\
\mathrm{R} \\
\mathrm{RR}\end{array}$ & $\begin{array}{l}0 \\
\mathrm{P} \\
\mathrm{P}\end{array}$ & $\begin{array}{c}60001-61000 \\
6001-7000 \\
15001-1579008001-9000\end{array}$ \\
\hline $\begin{array}{c}5 / 12 / 90 \\
5 / 12 / 90 \\
3 / 20 / 92 \\
4 / 19 / 93\end{array}$ & $\begin{array}{l}7 \text {-NP } \\
\text { 7-NP } \\
\text { 7-NP } \\
\text { 7.NP 7.NP }\end{array}$ & $\begin{array}{c}101 \\
358 \\
459 \\
1000998\end{array}$ & $\begin{array}{l}\mathrm{R} \\
\mathrm{R}\end{array}$ & $\begin{array}{l}Y \\
Y \\
O \\
O\end{array}$ & $\begin{array}{l}39501-39650 \\
40001-40400 \\
29001-3000064001-65000\end{array}$ \\
\hline $\begin{array}{c}5 / 4 / 93 \\
5 / 20 / 93\end{array}$ & $\begin{array}{l}\text { 7-NP } \\
\text { 7-NP }\end{array}$ & $\begin{array}{l}1000 \\
1000\end{array}$ & $\begin{array}{l}\mathrm{R} \\
\mathrm{R}\end{array}$ & $\begin{array}{l}\mathrm{O} \\
\mathrm{O}\end{array}$ & $\begin{array}{l}36001-37000 \\
33001-34000\end{array}$ \\
\hline
\end{tabular}

Location Code:

$\begin{array}{ll}\text { 0-NP } & \text { Northport } \\ \text { 1-NP } & \text { Kettle Falls } \\ \text { HC-NP/2-NP } & \text { Hall Creek } \\ \text { 3-NP } & \text { Hunters } \\ \text { 5-HR } & \text { Spokane Tribal Hatchery Release } \\ \text { 5-TNP } & \text { Tribal Net-Pen } \\ \text { 6-NP } & \text { Seven Bays } \\ \text { L-NP/6.5-NP } & \text { Lincoln } \\ \text { 7-NP } & \text { Keller Ferry }\end{array}$

Tag Color Code

Y-Yellow

O-Orange

P-Pink

B-Brown 